SCHOOL OF GEOGRAPHY, ENVIRONMENT AND EARTH SCIENCES VICTORIA UNIVERSITY OF WELLINGTON

\title{
PACIFIC REGIONALISM
}

HISTORICAL ANACHRONISM, OR PATHWAY

TO FUTURE DEVELOPMENT?

\section{ELSPETH DAVIDSON}




\section{Abstract:}

This study looks at the relevance of regional organisations in the Pacific Island region. It analyses the history of the key regional organisations: the Secretariat of the Pacific Community (SPC) and the Pacific Islands Forum Secretariat (PIFS). Since their establishment, there has been extensive criticism of the work of these organisations. This study tests and analyses the issue of legitimacy within supra-national organisations, and questions whether regionalism in the Pacific is an anachronism of the past.

In the Pacific, regionalism puts out a compelling argument for its existence. Throughout the region, small island developing states are spread across the world's largest ocean. Pacific Island states face many challenges, including: small economies, geographical disadvantages, vulnerability to climate change, varying availability to resources and a diverse range of cultures and languages. Regionalism provides a chance for these island states to influence world policy, build capacity in the region, promote good governance, maintain peaceful neighbourly relations, and create positive development outcomes.

The methodology uses qualitative research of document analysis and semi-structured interviews with key informants. The research claims a social constructivist epistemology and uses an inductive conceptual framework in order to find solutions to the complex challenges of Pacific regionalism.

It was found that regional organisations need to increase their transparency in order to enhance their legitimacy. They need provide a clearer evidence base, where all Pacific people can recognise and understand the benefit of regional organisations. The organisations need to work strategically to be nimble and reactive to upcoming critical junctures and issues. Council of Regional Organisations in the Pacific (CROP) agencies need to coordinate better amongst themselves, open up communication with all stakeholders and create clearer mandates. In order to promote positive development, all stakeholders and Pacific people need to take ownership of these organisations, and support the Framework for Pacific Regionalism process. This study argues that there is great potential for regionalism in the Pacific, but this will only be possible if the region works collectively to enhance the legitimacy of these organisations. 


\section{Acknowledgements}

Firstly, I would like to give special thanks to my interview participants. I am so grateful that you all accepted to take part in my research. Thank you for sharing your wisdom, ideas and experience.

The process of writing this thesis would not have been possible without the generous support of my supervisor, John Overton, my fellow Development Studies students, my family and friends. Thank you all for listening and being patient. Thank you Clae Baxter for helping me with the design of my title and chapter pages. Thank you to my father, John Davidson, for proofreading and fact checking. Thank you to my family for being with me, from the other side of the Tasman. Finally, thank you to coffee for keeping me focussed and buzzing.

This thesis is dedicated to the people of the Pacific. 


\section{List of Acronyms}

ACP - African, Caribbean, and Pacific

ADB - Asian Development Bank

APEC - Asia-Pacific Economic Cooperation

ASEAN - Association of Southeast Asian Nations

CARICOM - Caribbean Community

COA - Compliance Advisor Ombudsman

COP21 - 2015 Paris Climate Change Conference

CRGA - The Committee of Representatives of Governments and Administrations

CROP - Council of Regional Organisations in the Pacific

EC - European Commission

EEZ - exclusive economic zone

EPG - Eminent Persons' Group

EU - European Union

FEMM - Forum Economic Ministers Meeting

FFA - Forum Fisheries Agency

FFA - Forum Fisheries Association

FIC - Forum island country

FOC - Forum Official Committee

FTA - free trade agreement

GDP - gross domestic product

ICT - Information Communications Technology

IMF - International Monetary Fund

KRAs- Key Results Areas

MSG - Melanesian Spearhead Group

NAFTA - North American Free Trade Agreement 
NGO - nongovernment organization

OAU - African Union

PACER - Pacific Agreement on Closer Economic Relations

PASO - Pacific Aviation Safety Office

PIASA - Pacific Islands Air Services Agreement

PIDP - Pacific Islands Development Programme

PIF - Pacific Islands Forum

PIFS - Pacific Islands Forum Secretariat

PNG - Papua New Guinea

PPA - Pacific Power Association

PTA - Preferential Trading Agreements

RAMSI - Regional Assistance Mission to Solomon Islands

RSE - Recognised Seasonal Employee

SG - Secretary General

SPC - Secretariat of the Pacific Community

SPNFZ - South Pacific Nuclear Free Zone or Treaty of Rarotonga

SPREP - South Pacific Regional Environment Programme

SPREP - South Pacific Regional Environmental Programme

SPTO - South Pacific Tourism Organisation

UN - United Nations

UNCLOS - United Nations Convention of the Law of the Sea

UNDP - United Nations Development Programme

USP - University of South Pacific

VUW - Victoria University of Wellington

WTO - World Trade Organization 


\section{Table of Contents}

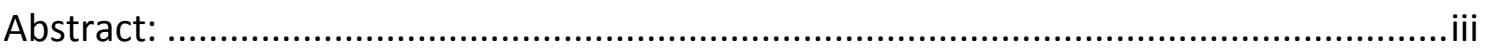

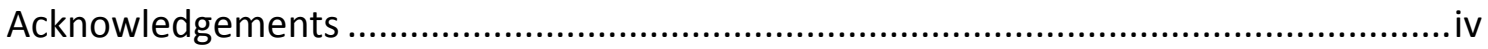

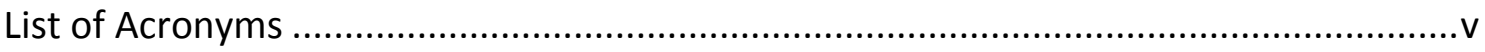

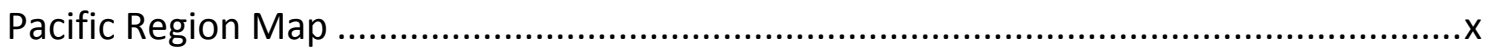

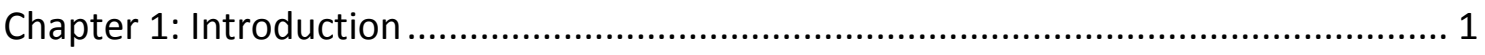

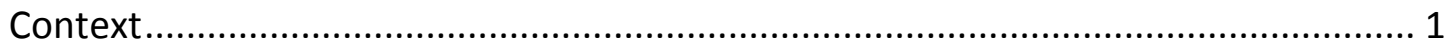

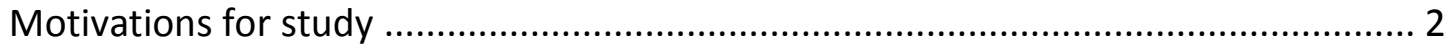

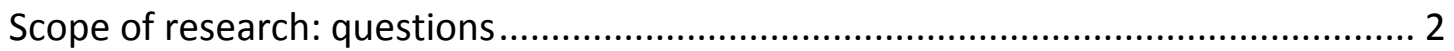

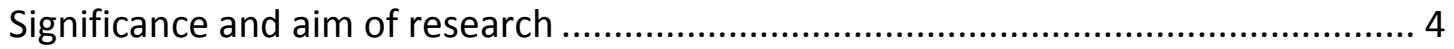

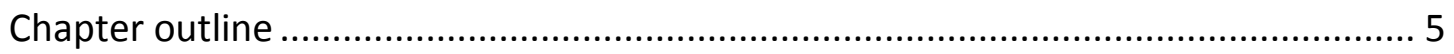

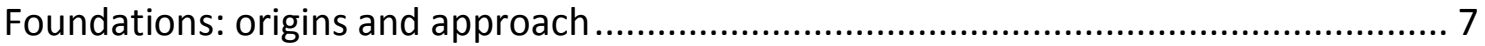

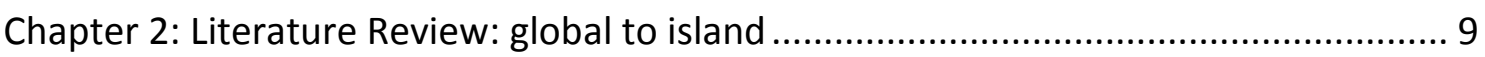

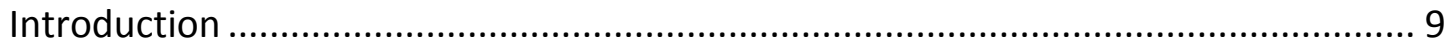

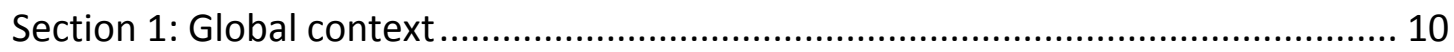

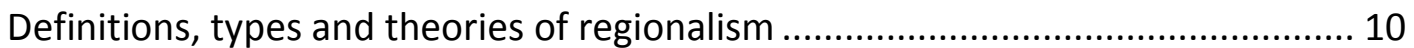

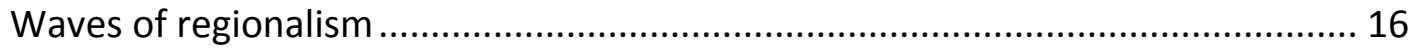

Modern day - benefits and challenges ............................................................... 19

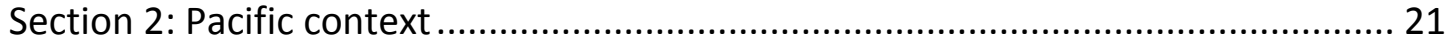

Definitions, types and theories of regionalism .................................................. 21

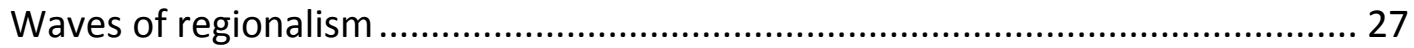

Modern day - benefits and challenges ........................................................... 31

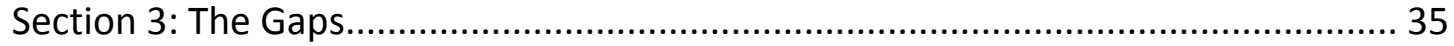

Critical junctures, effective management, and legitimacy ................................ 35

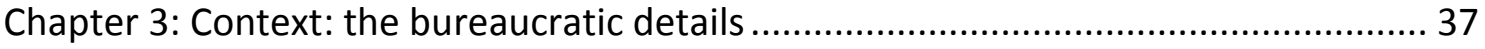

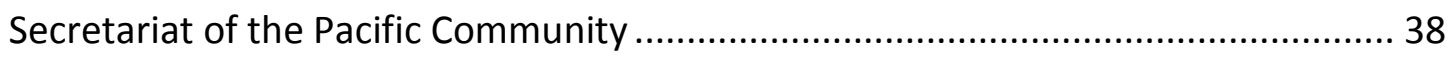

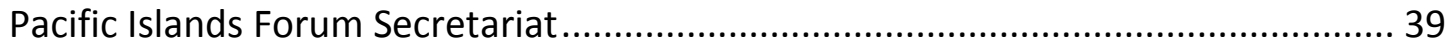

Council of Regional Organisations in the Pacific (CROP) Agencies........................... 41

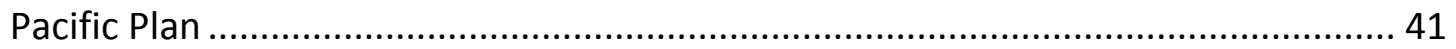

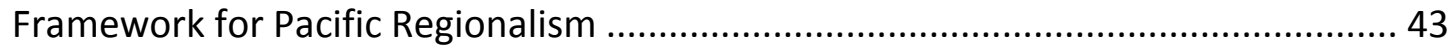


Chapter 4: Methodology: the theories and the ways ................................................ 51

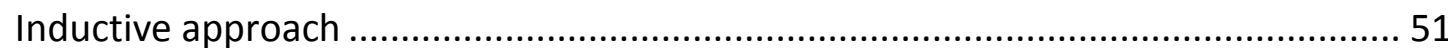

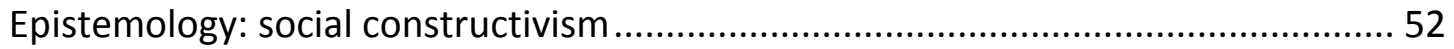

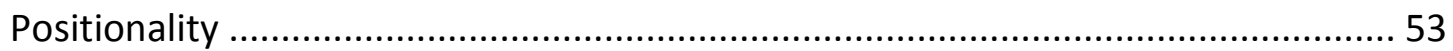

Methods: qualitative data ................................................................................ 54

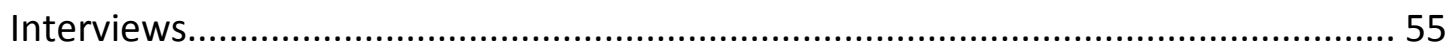

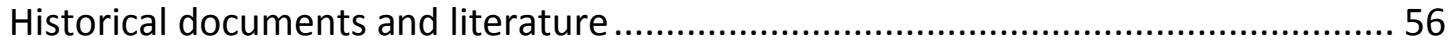

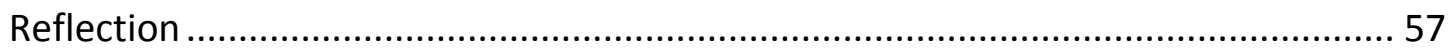

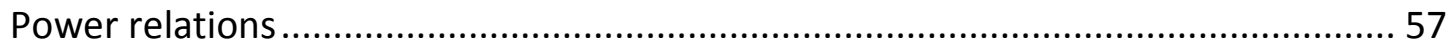

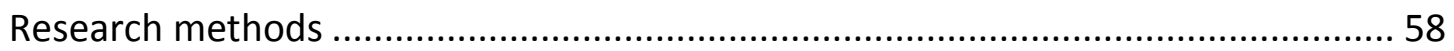

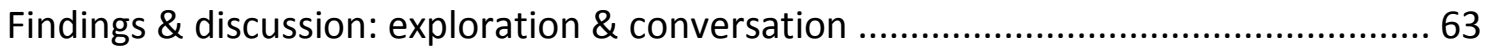

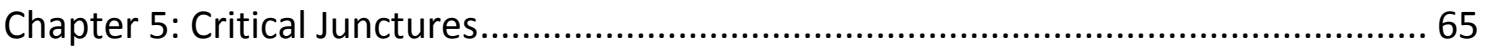

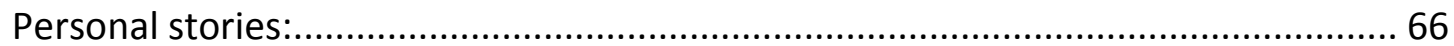

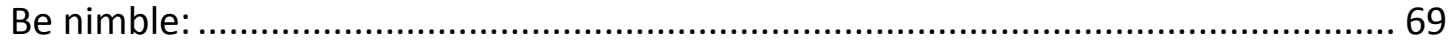

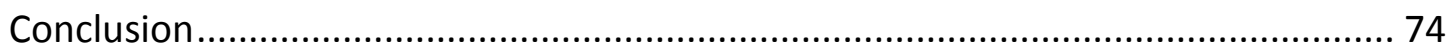

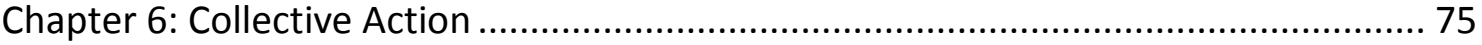

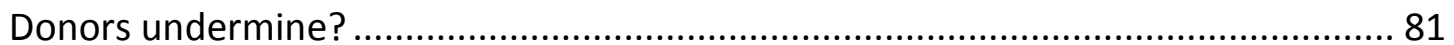

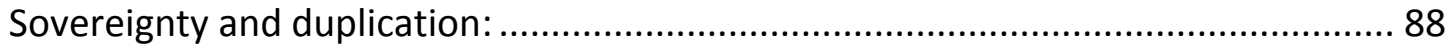

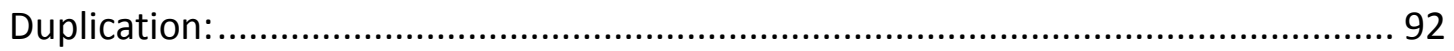

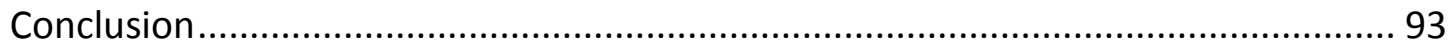

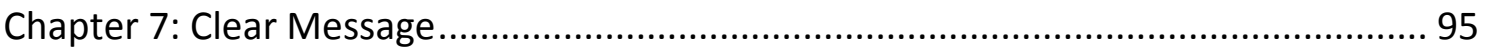

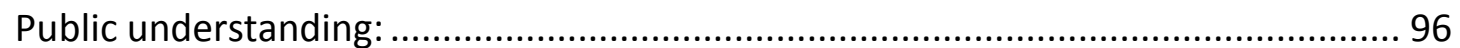

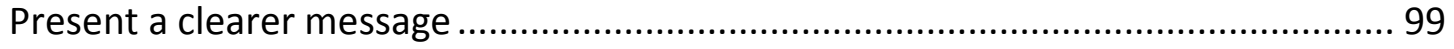

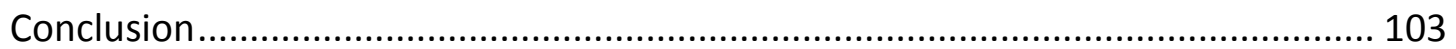

Chapter 8: Conclusion \& Recommendations............................................................ 105

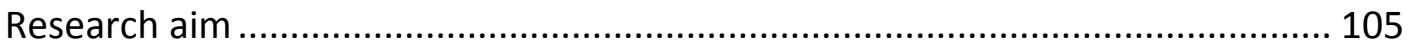

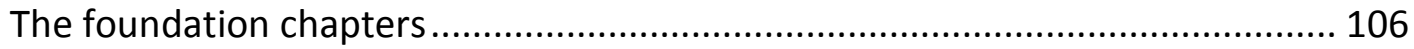

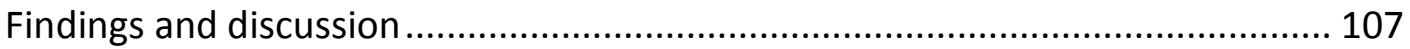

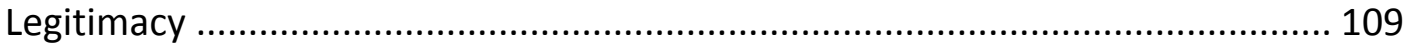




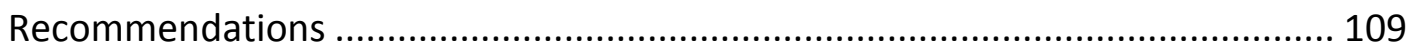

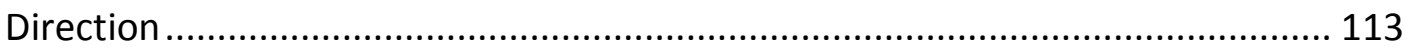

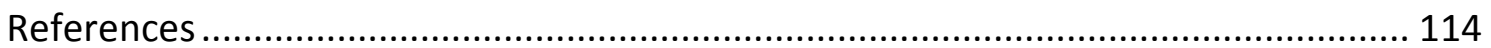

Appendix

Appendix 1: the Framework for Pacific Regionalism process ................................ 125

Appendix 2: Victoria University of Wellington Human Ethics Committee forms..... 126

\section{List of Figures}

1: Explanation of the elements of legitimacy............................................................. 14

2: Structure of the Pacific Islands Forum 45

Secretariat

3: Council of Regional Organisations in the Pacific (CROP)....................................... 46

4: Conceptual Framework..................................................................................... 59

5: Document analysis $\quad 60$

sample 


\section{Pacific Region Map}

(Secretariat of the Pacific Community c, 2011) 


\section{INTRODUCTION}

Context

The popularity of the idea of regional integration and cooperation has been growing over the past decades. The concept of independent sovereign states joining together to address global issues is not new, but with the experience of the European Union (EU) and Association of Southeast Asian Nations (ASEAN), other regions around the world are supporting further cooperation in pursuit of improved social and economic development (Chand, 2011: p. 2). Regionalism appears in varying forms, but typically refers to large institutions that work together to improve specific goals for nation states within close geographical proximity (Pacific Plan Review, 2013: p. 2). The foundation of this research project is focussed on how nation states join together to address capacity restraints and pool resources to support improved development through regional organisations and institutions.

In the Pacific, regionalism puts out a compelling argument for its existence. Throughout the region, small island developing states are spread across the world's largest ocean. Pacific Island states face many challenges, including: small economies, geographical disadvantages, vulnerability to climate change, varying availability to resources and a diverse range of cultures and languages. Pacific regionalism provides a chance for these small island developing states to influence world policy, build capacity in the region, promote good governance, maintain peaceful neighbourly relations, and create positive development outcomes. The Pacific region has ten major regional intergovernmental organisations, known as Council of Regional Organisations in the Pacific (CROP). These organisations serve different sectors and challenges in the region. The two key organisations among them are, the technical services agency, the Secretariat of the Pacific Community (SPC) and the political platform and organisation, 
the Pacific Islands Forum (and its accompanying secretariat) (Chand, 2011: p. 3) (Bryant-Tokalau \& Frazer, 2006, p. 1).

\section{Motivations for study}

The key motivator for this study was my experience as an intern at the Pacific Islands Forum Secretariat. While working on ocean policy, I was exposed to many of the successes and challenges of this form of development. I was given a unique insight into the internal processes of a regional organisation and was given the opportunity to witness high-level regional affairs. I have grown up around the Pacific region and formed a passion for the region, its complexities and development. Furthermore, a number of significant developments within Pacific regionalism have occurred in recent past. Both key organisations (i.e. PIFS and SPC) have new chief executives, the oncesuspended Fiji has been invited back in the Forum, and the Framework for Pacific Regionalism has been introduced to improve dialogue (Bola-Bari, 2015; Placek, 2014; Dornan \& Newton Cain, 2015). In international affairs, there has also been discussion about the effectiveness of multi-national organisations as a mode of development. There have been substantial conversations about the future of regionalism in the Pacific in academia and in the media. This thesis gives me the opportunity to use my unique insights and experience to explore some of the most challenging issues facing regionalism in the Pacific.

\section{Scope of research: questions}

Although regionalism has arguably found some success in the Pacific, in more recent years this alternative form of development has received substantial criticism and review. This research project aims to analyse the history of Pacific regionalism, particularly through CROP, and ask the question of whether this mode of development assistance and cooperation is a useful construct for Pacific Island countries, or if it is an out dated practice. This research project will focus on the Pacific Islands Forum Secretariat, with a secondary study on the Secretariat of the Pacific Community. Since their establishment, Pacific regionalism has faced many challenges, including issues of state sovereignty, legitimacy, unequal power relations, overly bureaucratic institutions, geographical isolation, collective action and conflicting interests (Asian Development Bank \& Commonwealth Secretariat, 2005: p xiii-xiv). Therefore this thesis aims to 
address the lack of in depth analysis of legitimacy in Pacific regionalism. It will look at what legitimacy means for regional organisations and apply it to the Pacific context. Legitimacy is vital in order for these organisations to be effective: without the on-going support of stakeholders and elected representatives, regional organisations will struggle to influence development. The research analyses legitimacy through three sub-themes: (1) critical junctures, (2) collective action and (3) a clear message. These three ideas will be explained and analysed in the findings and discussion chapters of this thesis. Each sub-theme has been developed from analysing Pacific documents (historical and recent) and relevant literature. (1) Critical junctures are moments in history that have sparked change within the region, and potentially heightened legitimacy the legitimacy of these organisations. (2) Collective action is defined as people coordinating together to enhance the response to regional issues and achieve a common objective to provide benefit to the region's wellbeing, and is the basis of regional cooperation. (3) A clear message concerns the regional organisation or platform's ability to convey and represent its work to all stakeholders in order to create ownership and encourage legitimacy.

Based on these sub-themes, the key research questions are:

- How can Pacific regionalism make a productive effort to encourage collective action? And furthermore, how can a balance be found between protecting state sovereignty while fostering collective action and legitimacy?

- What is the future of Pacific regionalism, and what is the best institutional framework to enhance and maintain ongoing legitimacy of regional organisations?

- How can Pacific regional organisations present a clearer message that Pacific people, at different levels, understand and feel ownership over?

- Do critical junctures support legitimacy? And if so, how can regional organisations be supported to position themselves to recognise and act on any critical juncture?

- How can the region ensure that the prominent role of donors does not undermine the legitimacy of Pacific regional organisations? 


\section{Significance and aim of research}

The key significance of this research derives from how it explores Pacific regional organisations from a new perspective, through legitimacy. Regional cooperation may provide a possible solution to some of the Pacific's most complex and pressing collection action issues, such as climate change. Since the establishment of the Pacific Islands Forum and the Pacific Community, many have questioned their role and have been sceptical about the use of multi-lateral development alternatives. Their legitimacy has been called into question by a number of members (e.g. Fiji) and external actors (e.g. China). However this research argues that the Pacific can manage their organisations well and give the region's citizens a sense of ownership. There is great potential for development success. Well-functioning states that can draw on a range of mechanisms to meet their citizens' needs are essential to the welfare and security of the entire region, including for donors. It is also becoming increasingly apparent that the smaller states of the Pacific will never be able to provide the full range of services associated with functioning states, both domestically and in the international arena. Therefore, it is vital that these regional organisations are seen, valued and engaged with as legitimate players in this complex mix. The Framework for Pacific Regionalism is in its first year of implementation and many are waiting to see if it is an effective solution (Placek, 2014). This thesis contributes to the debate at this important time, and brings to light whether these organisations have the authority to act, or are merely a historical anachronism left over from the geopolitics of the $20^{\text {th }}$ century.

The aim of this research project is to find practical solutions to adjust and legitimise the role of Pacific regional institutions to support future positive development. As well as seeks to contribute to changing understandings within the Pacific regional environment, in particular through the growth of the Framework for Pacific Regionalism. It is hoped that the conclusions of this research will promote dialogue around the importance of on-going legitimacy in these organisations, and encourage Pacific people to take hold of their regional affairs. 


\section{Chapter outline}

Following the introduction, the Literature Review provides an analysis of global literature and connects it with the Pacific context. This chapter also discusses other elements included in the findings and discussion, such as legitimacy and critical junctures. Chapter 3 provides a context of the regional organisations studied in this research, as well as some of the recent important events or documents that have shaped regional architecture. This is followed by the Methodology, the fourth chapter in thesis, which outlines research methods, epistemology, positionality, the conceptual framework, as well as reflections of the overall research process. In chapters 5-7, I explore and analyse the data collected. These three chapters are the findings and discussion of the research. They have been separated into three sub-themes of legitimacy: Chapter 5: Critical Junctures; Chapter 6: Collective Action; and Chapter 7: A Clear Message. The final chapter of this thesis is Chapter 8: Conclusion. This chapter provides recommendations for the application of Pacific regionalism, it reflects on the overall ideas of legitimacy in regional organisations and provides a summary of my overall findings. 



\section{FOUNDATIONS:}

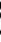

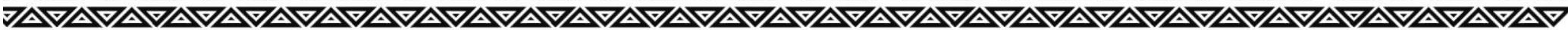

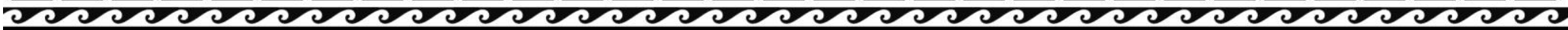

ORIGINS AND APPROACH 


\section{LITERATURE REVIEW: \\ GLOBAL TO ISLAND}

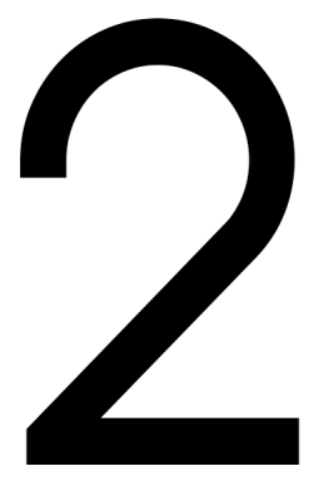



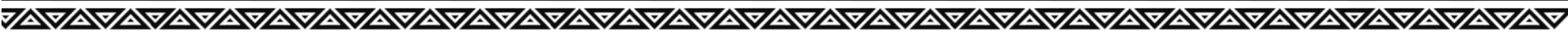

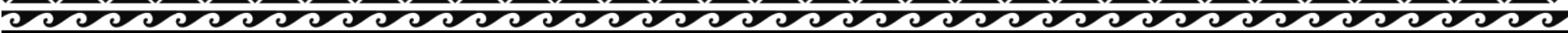

\section{Introduction}

The aim of this chapter is to position the research within the wider literature and arguments of regionalism. The foundation of this research is focussed on how nation states join together to address capacity restraints and pool resources to support improved development through regional organisations and institutions. This chapter will explore background concepts and provide a solid context in order to understand where the arguments have arisen. The concept of regionalism appears in many forms, the reasons for its existence in many parts of the world also widely vary, but upon studying the key literature it is evident that there are themes and trends that stretch across the globe. Due to the complex and differing nature of regionalism, it is difficult to define and even more challenging to find solutions to make it an effective form of transnational cooperation. This chapter is divided into two sections: a global context; and a Pacific context. The first section will explore definitions and theories of regionalism; the different waves in the popularity of regionalism over the past 75 years; and finally analyse the different debates on the benefits and challenges of modern regionalism. This section will explore popular literature and debates on regionalism, as well as provide a foundation to understand and interpret the Pacific context. The second section uses a very similar structure, and it will be organised as a mirror to the first section to compare and contrast the global and Pacific experience. It will explore the differences in Pacific regionalism and the contribution the global theories and events have made to the region. However, I will argue that gaps remain within the literature. In particular, there is a lack of discussion and analysis on the importance of political legitimacy of these organisations. This chapter will aim to ask questions about 
how legitimacy can be sought through regionalism, look at the power of collective action and transparency, and analyse how 'critical junctures' in history have been used to find acceptance and recognition of these institutions.

\section{Section 1: Global context}

\section{Definitions, types and theories of regionalism}

\section{Context}

The concept of regionalism or a regional community is not new (Hurrell, 1995, p. 41) (Fawcett, 1995, p. 10). For hundreds of years, populations have found commonalities and grouped together. The key difference in more recent times is that regionalism has become increasingly formalised (Fawcett \& Hurrell, 1995, p. 5). Regionalism appears in varying forms, but typically refers to large formalised institutions that work together to improve specific goals for neighbouring nation states (Pacific Plan Review, 2013: p. 2). Softer versions of regionalism or informal cooperation have existed, but in the past few decades, there has been a surge in institutions in the multilateral sphere (Hurrell, 1995, p. 39; Chand, 2011: p. 2). These institutions and mechanisms are targeted to collectively combat new kinds of challenges and non-traditional threats, particularly since so many have international or cross-border elements (Beattie, 2013, p. 7; Haas, 1992 in Beattie, 2013, p. 5). The new popularity in regionalism has also sparked an interest in academia, with more exciting and varied debates than ever before. In the literature there appear to be two key schools of thought: those concerned with economic welfare and the impact of the global market, and those concerned with political science and governance (who make up the majority of the literature) (Mansfield \& Solingen, 2010, p. 146; Nye, 1968; Buchanan \& Keohane, 2006). However, there still remains a body of literature that, despite the momentum, is sceptical of the use regional solutions in practical contexts and is more focussed on the strength of the nation-state (Crocombe, 1975, p. 1; Fawcett \& Hurrell, 1995, p. 5).

\section{Definitions}

One of the most contentious debates within academia and the practice of regionalism focuses on different all-encompassing definitions. Throughout the literature most authors suggest a definition for their specific argument or work and note that the term is quite ambiguous. In the most basic terms, most scholars seem to agree that 
regionalism means group-formation or collective coordination (Chand, 2011) (Hurrell, 1995, p. 38; Fawcett \& Hurrell, 1995, p. 5; Asian Development Bank-Commonwealth Secretariat, 2005, p. xv; Mansfield \& Solingen, 2010, p. 146); Russet, 1967 in Mansfield \& Solingen, 2010, p. 146). Regionalism currently is understood to involve cooperation or integration with sovereign states in close geographical proximity. This idea, however, is much debated among the academic world and is not always been the case in reality. The question then begs, what is a region? This is not a concept that can be defined scientifically, as scholars like Bruce Russett once tried (Hurrell, 1995, p. 38). The point where a region begins and ends is not always clear and, as Katzenstein (2005, p. 9) puts it, 'regions are politically made'. If it is not simply geographical, then as Hurrell (1995, p. 38) asserted, it is 'less than global'. It has also been related to the economic concept of 'club theory'; where the clubs must be self-sustaining and provide benefits for each of their members in order to be effective, for example military alliances, supranational organisations and cross boarder services (Asian Development BankCommonwealth Secretariat, 2005, p. xv; Chand, 2011). Scholars remark that it is more likely that a regional agreement or institution is based on social and cultural homogeneity, as well as common ideologies and economic status, on top of geographical proximity (Mansfield \& Solingen, 2010, p. 146; Russett, 1967; Hurrell, 1995 , p. 38). Perhaps the definition of regionalism is best left ambiguous, and understood like Mansfield and Soligen (2010, p.146) have argued, as the scope of a region is thus in the eyes of members of the dominant coalition.'

\section{Types and theories of regionalism}

Beyond searching for a basic definition, finding consensus on the type of regionalism and the governance has also proven to be widely complex and contested. As is evident in the literature, there is a lot of scepticism about the performance of multilateral agencies and this has called on more scholars and governments to question effective types of regionalism (Beattie, 2013, p. 7; Fawcett \& Hurrell, 1995). In order to be able to understand the role of governments, the private sector and civil society, as well as analyse trends of global fragmentation in the recent past, it is beneficial to analyse the reasons for regionalism and the different types (Mansfield \& Solingen, 2010, p. 159). Regionalism can range from cooperation between neighbours (i.e. diplomatic relations, 
collective action, etc.) to social or economic integration (i.e. trade agreements, shared services, common currency, etc.), and it can also include varying forms of the two. Regionalism can include trade agreements, like Preferential Trading Agreements (PTAs) where members are granted preferential access to other members' markets or Free Trade Areas (FTAs) (Mansfield \& Solingen, 2010, p. 147). In some instances regionalism is voluntary, whereas in others it is bound by international treaties. It can be formalised through institutions, secretariats or conferences, or be through informal dialogue (soft regionalism) between nation-states or groupings of people (Mansfield \& Solingen, 2010, p. 159; Nye, 1968). This research will largely focus on formalised regional organisations, as well as their effectiveness over history and in the modern day. Formalised regionalism is particularly interesting to analyse as the organisations have members who invest in their performance and there is a bigger drive for positive outcomes (Beattie, 2013, p. 2). The question of governance extends to who is making the decisions: the secretariat or institution employees, politicians or other elites, citizens of the region, or perhaps civil society and the private sector play a part in decision-making (Mansfield \& Solingen, 2010, p. 159). Cornforth (2005 in Beattie, 2013, p. 8) defines governance as the systems and processes concerned with ensuring the overall direction, effectiveness, supervision and accountability of an organisation'. The different types of regionalism and governance in formalised institutions varies between different contexts and regions of the world. However upon analysing the literature it is evident that there are clear trends.

A common theme in the literature is the complexity of legitimacy in these types of institutions. Although there is not a specific focus on regional organisations, there is significant literature on the legitimacy of global governance institutions. These institutions, such as the United Nations, the World Trade Organisation and the International Monetary Fund, present very similar challenges and benefits to regional institutions. They are usually voluntary, run by representatives and use coordination to tackle widespread issues (Buchanan \& Keohane, 2006; Heiskanen, 2001; Junne, 2001; Gupta, 2001; Karlssoon Schaffer, 2010).

Political legitimacy can be broadly defined as the acceptance or recognition of authority by the public. Specifically, in order for states to govern effectively, they need 
citizens to support their existence. This body of literature sits within the political science or sociology schools and most commonly is used to refer to a population's recognition of the government within a state (O'Neil, 2010, p. 35). One of the major thinkers within the literature, Max Weber wrote about bureaucracy, and how states become legitimate and the different types of legitimacy. He believed that there were three types of legitimacy that came out of the 'right to rule': traditional, based from custom and history; charismatic, built from the ideas and manner of a leader; and rational-legal, based on rules and procedures (Weber \& Parsons, 1947).

Many of these ideas can be, and have been, applied to global governance institutions. The most prominent authors in this field are Allen Buchanan and Robert $\mathrm{O}$. Keohane. Their work is often used as a framework for legitimacy and has been peer reviewed by many of the field's top academics (including Andrew Hurrell and Joesph S. Nye). Buchanan and Keohane (2006, p. 417) put forward a 'Complex Standard of Legitimacy' which is criteria which they believe include the basic elements for an international organisation to gain and maintain legitimacy. They use the basis of traditional state legitimacy from Weber to Enlightenment Philosophes, such as John Locke. This 'Standard' will provide the basis of this research, as it establishes a clear set of principles that can be readily applied to any context, is one of the leading papers in this field, and arguably reflects the ideas of the majority of other scholars and theorists. The criteria are as follows: (1) democratic values and consent, (2) three substantive conditions: moral accountability, comparative benefit and institutional integrity, and (3) accountability and transparency (see Figure 1). They argue that, with these elements, international institutions are able to maintain on-going legitimacy. 
Figure 1: Explanation of elements 'Complex Standard of Legitimacy':

\begin{tabular}{|c|c|c|}
\hline (1) & Democratic values and consent & $\begin{array}{l}\text { The concept that institutions can only remain } \\
\text { legitimate if they are created through state } \\
\text { consent. The legitimacy would be even easier } \\
\text { to achieve with a strong democratic } \\
\text { government due to the influence of public } \\
\text { perception and participation. }\end{array}$ \\
\hline \multicolumn{3}{|c|}{ (2) Substantive criteria: } \\
\hline & moral accountability & $\begin{array}{l}\text { the understanding that institutions behave in } \\
\text { accordance with human rights and refrain } \\
\text { from policies that promote serious injustice }\end{array}$ \\
\hline & comparative benefit & $\begin{array}{l}\text { the institution is the most feasible, } \\
\text { economically sound and best option to meet } \\
\text { the need and provide mutual benefit to } \\
\text { members }\end{array}$ \\
\hline & institutional integrity & $\begin{array}{l}\text { The practices of the institution must not } \\
\text { undermine its core goals that justify its } \\
\text { existence }\end{array}$ \\
\hline & Accountability and Transparency & $\begin{array}{l}\text { Accountability: The standards of the } \\
\text { institution and its employees that are } \\
\text { required to be met, the information } \\
\text { availability to accountability holders to } \\
\text { measure performance, and the accountability } \\
\text { holder's ability to impose sanctions } \\
\text { Transparency: The need for information is } \\
\text { essential to meet all of the elements of the } \\
\text { 'Standard', particularly the accountability }\end{array}$ \\
\hline
\end{tabular}

(Buchanan \& Keohane, 2006, p. 417)

The concept of legitimacy of an institution is normative, it is about whether it is perceived to be legitimate. Therefore for legitimacy to be an issue, there must be widespread normative disagreement, where there is a belief that the institution does not meet its standards in order for its members to enjoy mutual benefit. As Buchanan and Keohane (2006) have stated, many institutions have a recognisable need, but unless it is believed to be worthy of support, it will not be able to maintain its legitimacy and exert influence. However legitimacy is constantly changing, where 
'institutions often take on a life of their own, and create constraints and opportunities neither intended nor anticipated by their founding fathers' (Karlssoon Schaffer, 2010, p. 4). This is a common theme with many institutions, and the issue rises of whether the institutions change due to their political environment or whether they become too bureaucratic to create change and promote on-going legitimacy.

Another common theme in the literature is whether the institutions are held responsible to the general public or the representatives of the member states, and whether broad-based public support is essential for legitimacy (Buchanan \& Keohane, 2006; Karlssoon Schaffer, 2010; Heiskanen, 2001). Heiskanen (2001, p. 6) argued that, unlike in the national context, there is not a direct relationship between intergovernmental organisations and citizens of member states. As the institutions are controlled by their democratically elected representatives, ordinary people have no access to decision-making, and therefore become a unified group. In this case, the institution is accountable to the representatives, who are therefore, the decisionmakers of an institution's legitimacy. However, Buchanan and Keohane (2006) argue that in order to maintain on-going legitimacy, institutions must still remain legitimate to the general public. They highlight a fundamental issue in the public obtaining a valid perception: the lack of information available to outsiders. They state that many outsiders assume the worst if they do not have access to the vital information and details of the inner-workings of an institution. The general public are taxpayers that the government of day needs to be accountable to, and widespread legitimacy will promote positive perceptions for future issues. The concept of legitimacy is hugely challenging and difficult to define in the state or global governance institution context. There are however, basic tenets that most scholars have set out to define how such an intangible concept could perhaps be attained or enhanced. Legitimacy is essential for an institution to effectively coordinate benefits in order to be on-going and relevant. Given the benefits and challenges of modern international or regional institutions, arguably there need to be frameworks in place to ensure a constant process of scanning and recognition, in order to provide the best possible support and outcomes. 


\section{Waves of regionalism}

Throughout the literature on formalised regionalism it is apparent that key moments in history has had a very influential role in the approaches and types of institutions. Important points in global history have sparked fervent debate where governments seek to tackle issues from a collective and regional perspective (Fawcett \& Hurrell, 1995, p. 2). Since the age of imperialism in the 1500 s and the industrial revolution, economics and politics have come to operate on a global scale, namely in the context of globalisation (Fawcett \& Hurrell, 1995, p. 1). There are examples of informal and formal platforms of regionalism occurring all around the world in history, as 'international forces' prove often to be the most effective and efficient alternative (Fawcett \& Hurrell, 1995, p. 3).

\section{1) World War II}

At the end of World Wars, the globe was at a turning point. The two world wars had demonstrated the effective power of alliances and cooperation was key to the survival of individual states. States understood that they were stronger if they worked together to fight common international threats and challenges. Although both wars had disastrous effects on the globe, they were also periods of technological innovation and inter-state cooperation. The invention of the atomic bomb in WWII was also a major driver to form alliances that protected states against one another (Mayall, 1995, p. 173; Fawcett, 1995, p. 11). Beyond this, scholars argue that by forming alliances, countries are more likely to use negotiation and more peaceful approaches to problem solving (Mayall, 1995, p. 173; Hameiri, 2009, p. 348). The League of Nations is cited as an early example of formalised regionalism, where issues were debated at high-level gatherings, and each member's input and cooperation was necessary (Fawcett, 1995, p. 11). Following the Second World War, states had learned their lessons from past coordination efforts and established the United Nations (UN). Although set up as a

global cooperation platform, scholars have observed that the UN has been a trigger for collective action at the regional level (Mayall, 1995, p. 173; Fawcett, 1995, p. 19). Many states formed coalitions with other members of their region with common challenges and ideologies in order to have their views strongly demonstrated on the 
international stage (Mayall, 1995, p. 172). As Fawcett and Hurrell $(1995$, p. 3) stated, national policies began to shape the international economy and states were increasingly influencing each other. From the literature on international relations and development, World War II was a significant turning point in the world, when the role of the nation-state was questioned and the prominence of group formation began to expand (Murray \& Overton, 2014).

\section{2) Decolonisation}

The second wave of regionalism is usually cited to be the period of independence. Between the 1950s and 1980s, colonies all around the globe began the process of decolonisation from dependent territory to independent sovereign state. It is evident that throughout history, independence movements spread throughout Africa, the Caribbean, South East Asia and the Pacific and regional organisations soon formed their wake ${ }^{1}$ (Fawcett \& Hurrell, 1995, p. 4). For many of these states, without the support of their coloniser for national and international affairs, the process of selfgovernment proved to be difficult. Scholars describe decolonisation as a time for selfdetermination and independence, a period of history where states could choose their own alliances and political platforms. The literature emphasises the importance of how developing nations could join coalitions with like-minded states (Mayall, 1995, p. 175) (Kothari, 1974 in Fawcett, 1995, pp. 26-27. They could also even join groupings with more powerful states in order to become more influential in the international arena, for example Mexico's inclusion in the North America Free Trade Agreement (NAFTA). In addition, former-Soviet republics were able to form cooperative alliances after having spent so long under the power of Russia (Fawcett \& Hurrell, 1995, p. 4). These countries had similar cultures, political experiences and economic backgrounds, which is claimed to be a good foundation for effective regionalism. Rajni Kothari (1974 in Fawcett, 1995, pp. 26-27) stated that regionalism in developing countries is a sensible option. Regionalism is seen as a way to 'moderate the excesses' and mitigate the amount of burden on governments, particularly emerging and weaker states. This could, arguably, be linked to theories of dependency and nationalism.

\footnotetext{
${ }^{1}$ Established: African Union (AU) in 2002, Caribbean Community (CARICOM) in 1973, Association of Southeast Asian Nations (ASEAN) in 1967, and South Pacific Bureau/Pacific Islands Forum (PIF) in 1973/1991 (Ferris \& Petz, 2013).
} 
However, as many scholars have cited, the reality of regionalism in developing countries is unfortunately not as positive (Fawcett, 1995, p. 30; Fry, 2004, p. 1; Dornan \& Newton Cain, 2014, p. 1). Literature varies in terms of successes and failures, but a common theme is that there is 'a loss of faith in the post-colonial state' that has led many to question the role of good governance at the regional level (Fry, 2004, p. 1). Decolonisation is an important critical juncture for developing states, and also a time when nationalism proves to be a dominant force where dependence from other countries is less of a focus. As Fawcett stated (1995, pp. 26-27), in the third world, 'given its wide and growing diversity in terms of wealth and power -it is hardly surprising that truly collective action of any kind has been difficult to achieve'. Although there are evident challenges, decolonisation throughout history has proven to not only be a major driver for regionalism, but has also encouraged and helped build effective independent sovereign states.

\section{3) The end of the Cold War}

Arguably the most influential wave of regionalism was the end of the Cold War, where decentralisation led to multi-polarity (Buzan, p. 208 in Fawcett, 1995, p. 20; Fawcett \& Hurrell, 1995, p. 1). This period starting from the late 1980s, sparked a massive shift in the way that states interacted with each other and popular political ideologies. Academics consider that the end of the Cold War, did not just see the establishment of new regional initiatives, it also saw a resurgence in old regionalist institutions. 'Regionalism and the call for strengthened regionalist arrangements have been central to many of the debates about the nature of the post-cold War international order' (Fawcett \& Hurrell, 1995, p. 1). It saw the end of Cold War East-West alliances, and a chance for states outside of the superpowers to have a chance to voice their views on the international platform (Fawcett, 1995, p. 21). As globalisation became more widespread, regionalism followed. As Friedberg (in Fawcett \& Hurrell, 1995, p. 1) stated 'Recent rhetoric notwithstanding, the dominant trend in world politics today is towards regionalisation rather than globalisation, toward fragmentation rather than unification'. The end of the bipolar system saw new challenges and therefore new forms of international cooperation. In the past the two superpowers had represented 
strong and unified voices, and scholars argue that to 'overcome marginalisation' and vulnerability, regionalism allowed states to collaborate to increase economic growth and promote security. In the experience of the African, Caribbean and Pacific states, regional grouping provided a local point of view to mitigate their challenges (Fawcett, 1995, p. 22). Some authors argue that the wave of regionalism came out of the success of the UN during the Cold War, considering it to be 'a natural outgrowth' (Fawcett, 1995, p. 19).

\section{Modern day - benefits and challenges}

In more recent years, the modality of regionalism has been further pushed and tested. Many authors and theorists discuss the concept of a 'new regionalism' that is even more complex than the past with indistinguishable lines between economics, security and political challenges. Where one type of challenge is intertwined with another, economic regionalism is used as a mechanism "by which broader security and political goals can be pursued' (Fawcett \& Hurrell, 1995, p. 4; Nye, 1968). Moreover, prominent commentators state that 'the policy community now sells integration as a fashionable solution to the region's economic problems' (Powell, 2005, p. 218). Fawcett (1995, p. 13) argued that outside of the EU there have been very few tangible results from regionalism. The 2015 Greek Crisis in the European Union (EU) has been a real test for models of deeper integration (The Economist, 2015). This is just one example that has seen a push away from multilateralism in foreign policy making, particularly in the East Asia, North American and Europe - the three super regions (Wyatt-Walter, 1995, p. 75). In that case, has the Cold War model really ended and can smaller economies promote their own ideas? Superpowers do still exist and remain dominant on the international stage (Fawcett, 1995, p. 31). It has been argued that 'there seem to be more forces to make regionalism work than ever before', but conversely 'regionalism...can offer no miracle cure for the evils of the world, and very many objections can, and have been raised as to its value' (Fawcett, 1995, p. 30). The key challenge to regionalism seems to lie in the separation between sovereign and regional affairs; these different identities and goals make progress difficult. In many states in the world, it is difficult enough to form a national identity, let alone a regional one. Without the complete buy-in from all 
member states within a regional institution, it can be exceedingly challenging to create tangible results (Fawcett, 1995, pp. 32-33). Beyond that, it is even 'difficult to negotiate and design durable clubs for pooled service delivery when participation is voluntary', which is often the case (Dornan \& Newton Cain, 2014, p. 9).

However, it is still difficult to argue that regionalism, or some kind of geographical cooperation does not produce tangible benefits. After all why would policy makers even bother to consider the alternative if they could not see a chance of success? A common approach for scholars is to offer suggestions on how this model can be adapted into something more effective. Most of this literature analyses best practice examples and the lessons that have been learned throughout history (Dornan \& Newton Cain, 2014, p. 10; Fawcett, 1995, p. 10; Powell, 2005, p. 218). Club theory, in the forms of integration and cooperation, speaks of the potential to reduce government capacity restraints, raise trade gains, lower investment risk and production costs, shrink the amount of bureaucratic issues, and even help people concentrate more on the private sector (Powell, 2005, p. 218; Dornan \& Newton Cain, 2014, p. 10). Each member of the club needs positive net benefits, and each institution needs a specific mandate that works in areas where states are challenged, and it cannot intervene in sovereign affairs (Asian Development Bank-Commonwealth Secretariat, 2005, p. xvi; Mayall, 1995, pp. 170-171). Some authors have suggested that due to the complexity of modern day cooperation, 'this newer version [of regionalism] will have limited application and shelf life' (Fawcett, 1995, p. 9). It is evident that all these benefits do not come without constraints and challenges. Upon analysing the literature and history, there are strong themes linked to the critical junctures of World War II, decolonisation and the end of the Cold War. Around the globe there have been moments in history where these institutions have proven to be effective and been given a legitimate place in world politics. Perhaps unsurprisingly there are strong similarities among different regions, as well as lessons that can be learned from each other. 


\section{Section 2: Pacific context}

\section{Definitions, types and theories of regionalism}

\section{1) Context}

In the case of the Pacific, regionalism provides a unique experience for small island archipelagos spread across a huge stretch of ocean. However, each state varies greatly in terms of limited resources, population size, ethnicity, vulnerability to climate change and other issues, as well as fragile governance. Although the history of regional interaction in the Pacific has existed for hundreds of years, it was officially implemented after World War II with the formation of the technical services organisation, the South Pacific Commission (now known as the Secretariat of the Pacific Community or SPC), and later the South Pacific Bureau for Economic Cooperation (now known as Pacific Islands Forum with its accompanying secretariat) (Chand, 2011: p. 3). Over the past 60 years, regionalism has extended to nine major intergovernmental organisations, known as the Council of Regional Organisations in the Pacific (CROP) (see Figure 2 \& 3), as well as over 1000 non-government organisations targeting development issues from a regional perspective (BryantTokalau \& Frazer, 2006, p. 1; Australian Department of Foreign Affairs and Trade, 2013; Rapley, 2006, p. 2). This research will focus on the two largest regional organisations, SPC and PIFS. Since their establishment, Pacific regionalism has faced many challenges, including issues of state sovereignty, legitimacy, unequal power relations, overly bureaucratic institutions, geographical isolation, collective action and conflicting interests (Asian Development Bank-Commonwealth Secretariat, 2005: p xiii-xiv). Therefore this research aims to address the lack of in depth analysis of historical junctures and legitimacy in Pacific regionalism, as well as find solutions for clear decision-making and reform suggestions to make regionalism effective.

Most research focussed on regionalism in the Pacific clearly identifies the usefulness of member-run institutions and challenges to effective governance. Since the establishment of the key CROP agencies, the Pacific political and economic environment has changed, and whether the policy has adapted accordingly is hugely contested among scholars and politicians alike. There is a particular focus on the 
unequal power relations between member countries, the bureaucratic and expensive nature of the organisations, and conflicting interests with few strong pushes for collective action, as well as the balance between state sovereignty and the power of these organisations (Dornan \& Newton, 2014: p. 1; Beattie, 2013: p. 2; Bryant-Tokalau \& Frazer, 2006: p. 2-3). From the literature, it is evident that there is some potential, but it is also clear that future regionalism will be determined by leaders' abilities to streamline institutional efforts and dictate the major strategic objectives for Pacific Island states. To address this gap in the literature, this research aims to investigate whether current forms of regionalism are a feasible and effective way of managing economic and social development in the Pacific, or if it is a concept that should be abandoned and left to history. With the outcome documents from the latest Pacific Islands Forum leaders meetings in Port Moresby, and the first year of implementation of the Framework for Pacific Regionalism, as well as the relatively recent appointments of a new Director General of SPC and Secretary General of PIFS, the future of regionalism is at an interesting cusp and will be defined by whether they can continue to provide this legitimacy (Placek, 2014; Secretariat of the Pacific Community, 2014).

On the whole, the governments and regional institutions of the Pacific have embraced global ideas and policies. They have tried to use economic reform, globalisation and other international policy trends as tools to benefit the region. It has been argued that perhaps they had no choice or could not ignore, as with so many of the Pacific states dependent on global aid money, these policies become part of associated aid conditionality and modalities (Rapley, 2006, p. 2). Pacific leaders have adopted models and policies from global institutions, such as the World Bank, the World Trade Organisation (WTO) and the International Monetary Fund (IMF). Many argue that the Pacific is so far disconnected from these entities that implementing these ideas is strange, and arguably not appropriate in these contexts. For example at the 1997 Forum Economic Ministers' Meetings (FEMM), leaders committed to the neo-liberal concepts of 'deregulating economic life, minimising subsidies, privatising government enterprises, assisting foreign investment, improving public accountability, reducing tariffs and moving towards complete free trade' (Rapley, 2006, p. 2). The extent to which these policy prescriptions can apply in countries like Tuvalu with a 
total land area of 24 square kilometres and a population of 10,000 is questionable. Climate change and environmental protection are recurring themes in Pacific policy and in discussion in high-level regional meetings and clear examples of where a need for collective action has united members of regional organisations. With fears of sealevel rise, global warming and resource scarcity, these issues have been uniting factors for Pacific Islanders, as the Eminent Persons' Group (EPG) who reviewed the Pacific Islands Forum stated the Pacific has been threatened by modernisation and globalisation, but 'nevertheless we shall stand strong to preserve our region, our heritage and the best aspects of our traditions, and enhance them for the benefit of future generations' (Huffer, 2006, p. 43). There is no doubt that the influence of European colonisation and the settlement by outsiders has shaped the region. On the other hand, it has also been expressed that 'the impact of western colonisation has meant dramatic and sometimes traumatic changes in the character and life styles of our peoples' (Momis, 1975, p. 81).

A key driver for the use of cooperation and regional alternatives in the region was to give the Pacific Islands a louder voice in the international arena. Most states had permanent representatives in the UN, but due to the high cost of hosting a representative and the necessary advisors, it has always been difficult for small developing states to influence the discussion. Neighbouring countries, Australia and New Zealand, had assisted the Pacific Island countries in the past with big negotiations and challenges (Frazer \& Bryant-Tokalau, 2006, p. 7). Through the PIFS, the member states are able to use collective diplomacy in order to achieve their objectives (Dornan \& Newton Cain, 2014, pp. 7-8). It is certainly argued that some of the greatest successes in Pacific regionalism have been the moments where Pacific states have expressed their self-determination through the PIF (Fry, 1994, p. 139). One of the best examples of this is the establishment of the United Nations Convention of the Law of the Sea (UNCLOS) which helped establish Exclusive Economic Zones (EEZ) and began the journey of regional tuna and fisheries management. This Convention was very important to the Pacific as many states rely heavily on fisheries for their gross domestic product (GDP) and had been experiencing commercial fishing from overseas boats in their waters for many decades (Frazer \& Bryant-Tokalau, 2006, p. 7). Another 
victorious moment for collective diplomacy in the Pacific was the ban on nuclear testing. Member countries joined and fought for their rights through international platforms, the International Court of Justice and UN General Assembly to set up Nuclear Free Zones. Through the collective pressure of Pacific governments, the United Kingdom and the United States agreed to cease all nuclear testing in the region, and only France remained. In the 1980s, the Australian Government under Prime Minister Bob Hawke proposed a South Pacific Nuclear Free Zone, and it was later signed as 'the Treaty of Rarotonga' (SPNFZ), one of the first agreements of this kind. Through strong advocacy by the PIF, the UK, the US and France all signed the Treaty in 1996 (Frazer \& Bryant-Tokalau, 2006, p. 9). By the 1990s and into the 2000s, the popularity of multilateral institutions grew among politicians, academics and the general populous (Frazer \& Bryant-Tokalau, 2006, p. 9; Dornan \& Newton Cain, 2014, p. 1).

As Pacific academic Greg Fry (1994, p. 137) argued, South Pacific regional cooperation is not just about the Forum and its history, as could be said about South-East Asian cooperation through ASEAN or African cooperation with African Union (OAU) or Caribbean cooperation with Caribbean Community (CARICOM). It is about the relations between the organisations and networks: how the CROP agencies work together and other forms of regional cooperation. Although scholars (Fawcett \& Hurrell, 1995, p. 5; Fry, 2015, p. 5; Frazer \& Bryant-Tokalau, 2006, p. 4) are quick to point out the flaws in regional cooperation, very few provide practical reasons and solutions for how it can be reformed to become more effective. One of the key interests of this research will be to look specifically at critical junctures in history and how there have been the moments where these types of organisations have played a legitimate and successful role in tackling issues. Another component will be reviewing ways that meetings and decision-making processes can be designed more effectively to benefit all member states.

\section{2) Difference with the Rest of the World}

As stated in The Framework for Pacific Regionalism, Pacific Forum Leaders understand regionalism as: 
'The expression of a common sense of identity and purpose, leading progressively to the sharing of institutions, resources, and markets, with the purpose of complementing national efforts, overcoming common constraints, and enhancing sustainable and inclusive development within Pacific countries and territories and for the Pacific region as a whole' (Pacific Islands Forum Secretariat, 2014, p. 1)

The Pacific is a unique region. Although it adopts many of its policies and regionalism mechanisms from global experiences, the region has its own way of tackling issues (Frazer \& Bryant-Tokalau, 2006, p. 1; Fry, 2004, p. 5). To start with, the environment of the Pacific Islands make the challenges different. The Pacific Islands are clusters of small, isolated archipelagos spread across of hundreds of thousands of square kilometres of ocean. Of course political differences exist across the region, but due to such similar histories and colonial backgrounds, there are a lot of similarities that can be used to mediate debates. Scholars argue that unlike other parts of the world, such as Asia and Africa, the chances of conflict and tension between Pacific Islands is much rarer due to shared histories, in particular, their shared colonial experiences. The two key priorities of Pacific regionalism are respect of sovereignty and economic development (Frazer \& Bryant-Tokalau, 2006, p. 6). Differences are, instead, 'restricted to the issues at hand' (Fry, 1994, p. 144). A common theme among Pacific Islands is capacity constraints, namely public financial management, infrastructure maintenance, service delivery and isolation (Dornan \& Newton Cain, 2014, p. 2). Many Pacific Island governments are unable to perform the same functions as larger countries and these vary greatly from small economies such as Kiribati to larger economies such as Fiji. A classic example used in the literature is the idea that a full-time brain surgeon is unrealistic in Nauru (Dornan \& Newton Cain, 2014, p. 7). The popular argument in the literature is that regionalism is not just useful in the Pacific, but rather that there is a real need for cooperation in order to provide citizens with efficient and basic services (Dornan \& Newton Cain, 2014, p. 8). Hameiri (2009, p. 348) argues that these newer forms of regionalism in the Pacific are 'novel' as aspects of it do not look at the interstate, but rather the individual states. Much of this argument stems from the experience of Regional Assistance Mission to Solomon Islands (RAMSI) where Pacific Island governments united to help the government and people of the Solomon Islands. 
One of the most unique and complex attributes of Pacific regionalism is the inclusion of metropolitan states. As mentioned earlier, SPC includes colonising states, but the real difference is Australia and New Zealand's presence in PIFS. As Greg Fry argued, why include two colonial powers when the main goal of creating this new organisation was to promote self-determination and independence from colonial states? Other regions, such as the Caribbean and South East Asia, did exactly the opposite. It was seen as an 'unusual' decision, but necessary to preserve influence with the two most dominant powers in the region and key trade partners. The leaders argued that it was formed to serve developing countries, not developed (Fry, 1994, p. 140). However, the economic viability of the key regional institutions rests on the contributions from the metropolitan countries due to the limited resource base of smaller Pacific island members. (Fry, 1994, p. 149). This topic will be further discussed later in the chapter: in the Modern Day section.

Geographically the Pacific is made up of islands, however one cannot forget that it is one of the most culturally diverse regions in the world. Papua New Guinea alone has over 850 languages, Fiji is a bi-cultural society with its large Indian Fijian population, and there are very small, but very culturally distinct, states such as Kiribati, Tuvalu and Nauru (Fry, 2004, p. 6; Frazer \& Bryant-Tokalau, 2006, p. 12; Fry, 1994, p. 148). Beyond this, the Pacific also has three major ethnic groups: Polynesians ${ }^{2}$, Melanesians ${ }^{3}$ and Micronesians ${ }^{4}$. Melanesia is a sub-region of the Western Pacific with distinct cultural identities and traditions (Powell, 2005, p. 237). The classic model of Melanesia centres on the so-called Big-Man society, whereas Polynesia is focussed around hierarchical chiefly systems (see Sand, 2002). In 1986, in order to bring light to the sub-region's interests, the Melanesian Spearhead Group (MSG) was formed (Fry, 1994, pp. 146-147). Although MSG is the most dominant of the three sub-regional identity groups, the Polynesian Leaders' Group and the Micronesia Chief Executives' Summit also play active roles in highlighting their perspectives (Newton Cain, 2012). In 1985, the Forum

\footnotetext{
${ }^{2}$ Polynesia consists of Samoa, Tonga, the Cook Islands, Tuvalu, Tokelau, Niue, Wallis and Futuna and French Polynesia

${ }^{3}$ Melanesia consists of Vanuatu, Solomon Islands, Papua New Guinea and Fiji

${ }^{4}$ Micronesia consists of Kiribati, the Marshall Islands, the Federated States of Micronesia, Nauru, Palau
} 
Communiqué established the Committee of Small Island States ${ }^{5}$, stating that they 'deserve special attention' (Fry, 1994, p. 148). Each of the sovereign states and subregions has distinct features, but the regional agencies aim to provide a platform where technical and policy issues can be discussed and Pacific regional responses developed and implemented.

\section{Waves of regionalism}

\section{1) World War II}

As within the global context, regionalism is not new in the Pacific and its popularity has ebbed and flowed in waves (Dornan \& Newton Cain, 2014, p. 8). Pacific regionalism has also had three distinct waves followed by historical events: World War II, decolonisation and the end of the Cold War (Frazer \& Bryant-Tokalau, 2006, pp. 5-14; Dornan \& Newton Cain, 2014, p. 7). As mentioned above in the global section, the end of World War II was an important point in history for regionalism. The Pacific was heavily involved in the Japanese-United States conflict, and Pacific states were greatly affected by the devastation. The end of the war was a chance to change international relations, and Pacific countries 'were concerned to create a post-war regional order that suited their interests rather than leaving it to the new United Nations' (Fry, 1994, p. 136). Most scholars view the beginning of formalised Pacific regionalism after World War II in the colonial days (Dornan \& Newton Cain, 2014, p. 7). Initially known as the South Pacific Commission, SPC was set up as a strategic move where the administrative territories could continue the 'Pacific Alliance' through an institutionalised platform. Formalised regionalism gave colonisers a platform to negotiate their power over the Pacific, and allowed Pacific Island governments assistance to rebuild after the War (Frazer \& Bryant-Tokalau, 2006, p. 5). Members included Australia, France, New Zealand, the Netherlands, the United Kingdom and the United States of America. Although many of the members have changed over time ${ }^{6}$, the same principle remains for the institution: providing technical services to maintain stability across the region (see Context chapter for more information) (Secretariat of the Pacific Community $f$, 2011). What is evident from the literature, World War II catalysed a moment in history,

\footnotetext{
${ }^{5}$ Small Island states: Cooks, Kiribati, Tuvalu and Nauru

${ }^{6}$ The Netherlands exited the SPC in 1962, and the United Kingdom exited in 2004
} 
a critical juncture, where cooperation between states proved to be a good option to improve development outcomes.

\section{2) Decolonisation}

Pacific Island nations began the process of independence much later than other countries around the globe. However, the Pacific followed a very similar path of sovereignty to other regions, and created their own regional institutions. Upon independence of many Pacific Islands, leaders began to feel that they did not play a strong enough role in the decision-making at the SPC. In front of the UN General Assembly, the former Prime Minister of Fiji, Ratu Sir Kamisese Mara argued that there was a 'Pacific Way', stressing the identity of the region and the importance that Pacific leaders have control of their sovereignty and identity (Fry, 1994, p. 142; Mara, 1997, p. 170). Reflecting on the 'rebellion of the Commission' and the formation of the PIF, Ratu Mara stated:

'...the powers seemed incapable of realising that the winds of change had at last reached the South Pacific and that we peoples of the territories were no longer going to tolerate the domination of the Commission by the Metropolitan powers. We were sick of having little to say and no authority' (Mara, 1974, p. 2 cited in Fry, 2015, p. 4).

These arguments created structural changes within SPC and eventually pushed for the establishment of a Pacific-only institution, the South Pacific Bureau (now PIF), said to be based on self-determination and political affairs (Fry, 2004, p. 6). The ban on all political discussion in SPC, meant that very little changed in favour of the 'rebels' and they decided to form their own organisation (Fry, 1994, p. 139; Fry, 2004, p. 6; Mara, 1997, p. 168). 'They agreed that the new organisation should be built on egalitarianism (a rejection of the hierarchy of power in the colonial system)', and the PIF included only independent states and Australia and New Zealand, excluding dependent territories and other metropolitan states (Fry, 2015, p. 4; Fry, 2004, p. 6). The platform was a place where Pacific Islanders could control the agenda and speak of cooperation among the region (Momis, 1975, p. 81; Frazer \& Bryant-Tokalau, 2006, p. 6). It helped promote economic development and the political issues of newly independent states, 
maximising international diplomatic influence on issues that related to all members i.e. fishing and nuclear testing (Fry, 1994, p. 140; Fry, 2015, p. 4). The Forum also helped campaign for decolonisation in other Pacific states, such as the New Hebrides (now Vanuatu), New Caledonia (still not independent from France) and West Papua (still not independent from Indonesia) (Fry, 1994, p. 168).

Scholars have cited that Forum processes affected norms at the national level as well and helped with development coordination and new ideas of security (Fry, 1994, p. 171) (Fawcett \& Hurrell, 1995). Fry analysed that in the 1980s, during the Cold War, Australia and NZ did not dominate the outcomes of the Forums. They were formed, instead, through negotiation and 'were testimony to the legitimacy accorded to the understandings reached in 1971 about the principles of regional governance' (Fry, 2015, p. 5). At this point in history, scholars stated that the Australia and New Zealand governments 'recognised they had a partnership role to play, not the hegemonic role of the past' (Fry, 2015, p. 4; Frazer \& Bryant-Tokalau, 2006). In the first decade of the Forum an extensive decolonisation process saw the Forum double its member numbers as the number of independent states grew. This changed the climate and 'introduced new interests, priorities and identities'. Initially led by mainly Polynesians, Melanesian and Micronesian countries began to join (Fry, 1994, p. 142). Polynesia was the 'independent Pacific' for so long, but with the expansion of Melanesia, it was now important to talk about issues in terms of identity. The independence of PNG (1975) and the Solomon Islands (1978) triggered this change. The Melanesia states brought in new priorities and styles of negotiation, apparently more direct and uncompromising (Fry, 1994, p. 143) The Forum became the place where regionalism practices and norms were created, and this was reflected across the other regional organisations (Fry, 1994, pp. 144-145). This wave of regionalism demonstrated the importance of the sovereign state and was a chance for Pacific leaders to assert their self-determination and independence. 


\section{3) The End of the Cold War}

Coupled with the impact of the Cold War and the emergence of dominant global powers, the late 1980s and early 2000s saw a dramatic shift in regional ideas (Frazer \& Bryant-Tokalau, 2006, p. 13; Fry, 2015, p. 5). With so many new members a 'much more complex matrix of relationships' was created in the Pacific regional space. A major part of this was due to Australia and New Zealand's conservative governments. It has been suggested that after Tonga was offered assistance from the Soviet countries, they 'began to view the region through a Cold War lens' (Fry, 1994, pp. 144145). Regionalism became less significant to the metropolitan states. At the end of the Cold War, things began to change in terms of power and equality. The partnership that was the underlying foundation of the legitimacy of regional governance began to crumble and Australia and NZ adopted a more foreign policy driven approach: neoliberal and security focused. This was evident in both Australia and New Zealand through their domestic policies, but also extended to their bilateral and regional relationships (Fry, 2015, p. 5). Fry and other authors have stated that this was the point where Australia and New Zealand began to view themselves as the leaders of the region (Fry, 1994, pp. 145-145; Frazer \& Bryant-Tokalau, 2006, p. 13). The world saw an ideological shift toward realism, where the sovereign state was the most important and there was more focus on collective diplomacy (Fry, 1994, p. 146). The nature of regional security changed, and was no longer as important; it was not about war, but rather organised crime, drug trafficking, economics and the environment, namely nontraditional threats that could be addressed through regional means (Fry, 1994, p. 166). For example, a regional institution with the sole target of environmental protection was established: Secretariat of the Pacific Regional Environment Programme (SPREP) (Fry, 1994, p. 163). After September 11 2001, Australia began to view the region as more of a security and terrorist threat, the terms 'arc of instability' and 'failed state' began to appear in government policy. Regionalism took a more interventionist policy toward sovereign affairs, evident in RAMSI, the 1987 Fiji coup and Vanuatu's postindependence unrest (Frazer \& Bryant-Tokalau, 2006, p. 18; Dornan \& Newton Cain, 2014, pp. 7-8). This period also saw a major shift in the literature, with scholars changing their tone and beginning to argue against the dominance of Australia and 
New Zealand, and there are often suggestions to change the membership status of the two countries (Hughes 2005, p. 10 in Fry, 2015, pp. 5-6; Hameiri, 2009, p. 349).

\section{Modern day - benefits and challenges}

As noted in the sections above, a vast majority of literature on Pacific Regionalism focusses on its history. Reflecting on the modern day, much of the literature also discusses the concept of 'new regionalism'. This concept is occurring in other regions of the world, but with 'the Pacific Plan' and 'Framework for Pacific Regionalism', the Pacific is taking a very active role to become more effective in the modern age. The details of 'the Pacific Plan' and the 'Framework for Pacific Regionalism' will be discussed further in the context chapter of this research, but critique and criticism will be noted in the literature review. A common argument of Pacific Regionalism is that it has not changed much since the establishment of the two major institutions, in terms of the issues or the approaches. Some of the hottest debates still surround symbolism, sovereignty, economies of scale, and economic integration (Fry, 1994, p. 150). Other authors have asserted that 'regionalism is going through one of the most testing points in history' (Frazer \& Bryant-Tokalau, 2006, p. 5). Many scholars claim that this shift began with a change in leaders in Australia and New Zealand: both Kevin Rudd and Helen Clark expressed a desire for new approaches to Pacific relations (Huffer, 2006, p. 43; Frazer \& Bryant-Tokalau, 2006, p. 4). In 2007, Kevin Rudd spoke of a much softer diplomatic approach and wished to 'generate goodwill among Pacific leaders' (Hameiri, 2009 , p. 349). A common critique of 'new regionalism', particularly the Pacific Plan, is that it has a strong neo-liberal focus, with encouragement of free trade, the private sector, good (democratic) governance and a reduction in government burden and spending (Dornan \& Newton Cain, 2014, p. 8). One source suggested that this change in ideology was mainly dominated by Australian government policy, as they are the largest aid donor to the Pacific and have moved toward more controlled delivery (Frazer \& Bryant-Tokalau, 2006, p. 4). 


\section{1) Challenges}

The most common themes in the literature highlights the challenges and failures of Pacific Regionalism. There are a wide variety of challenges noted in the literature, but there are common themes and issues. For this literature review, four key challenges have been selected: the bureaucratic and management of the institutions; state sovereignty vs. regional power; economies of scale; and the dominance of Australia and New Zealand. In regard to the bureaucratic nature and management styles of the regional institutions, a reoccurring argument is that there is a lot of duplication among the institutions (Dornan \& Newton Cain, 2014, p. 15). This has been a common argument throughout the history of regionalism in the Pacific, and one of the reasons for the establishment of the CROP. Some authors (Dornan \& Newton Cain, 2014) have suggested that there should just be one major institution, i.e. a merger between SPC and PIFS. Others have suggested that the institutions need to focus on their differences and the demands to be most effective (Asian Development BankCommonwealth Secretariat, 2005, p. xviii; Fry, 1994, p. 137). Beyond the management, another common argument is that supranational organisations interfere and dominate sovereign affairs. Scholars have argued that by committing to the membership of supranational organisations, like PIFS or SPC, states lose their sovereign power, as they are pressured to agree and participate in policies and treaties. Arguably individual states have asserted that some challenges need to be tackled at the sovereign level and some through regional institutions. The question then begged is: which issues? (Frazer \& Bryant-Tokalau, 2006, p. 4; Fry, 1994, p. 155). It has also been noted that many states in the Pacific do not have a singular national identity or an internally shared view of 'state', this is especially evident in Melanesia (Powell, 2005, p. 237; Fry, 1994, p. 143). As Greg Fry (2004, p. 4) commented 'lacking coercive and socialising powers of the state, the regional political community [is] even more dependent on legitimacy as the basis of its political and moral authority'. The third theme is economies of scale. This argument is focussed on the fact that as each member state has different sized economies, and therefore the work of regionalism affects them in different ways. A prime example used in the literature is the arguably strong impact regionalism makes on Fiji. Based on its central location and transport options for the region, Fiji is often used as the hub. It hosts the headquarters for a number of regional 
institutions, including PIFS, SPC (regional headquarters), USP, as well as countless NGOs and international institutions. The needs of larger and smaller economies are very different, and therefore it is often difficult to create policies that evenly create benefits for all member states (Fry, 1994, p. 151; Frazer \& Bryant-Tokalau, 2006, p. 7). The final argument has been a common point of contention since the establishment of PIFS, i.e. the dominance of Australia and New Zealand. The establishment of PIFS was seen as a way to escape the colonial years and focus on Pacific matters (Fry, 2015, p. 3). As mentioned above, there were clear reasons for the inclusion of the two neighbouring metropolitan states (Fry, 1994, pp. 144-145). This argument extends to the dependency of the states to manage the institutions and their active role in decision-making, that has driven many scholars and politicians to suggest that the states need to take a 'step back' from the dialogue to encourage Pacific ownership (Fry, 2015, p. 10; Dornan \& Newton Cain, 2014, p. 12; Frazer \& Bryant-Tokalau, 2006, p. 3; Hameiri, 2009, p. 348). Dornan and Newton Cain (2014, p. 12) emphasised that as the development partners, i.e. Australia and New Zealand, are paying the majority of the costs to run the institutions, and are most likely doing so to pursue self-interest, as they want good value for money from their investment. In turn this means that Pacific members do not monitor the organisations and their performance, and this creates further issues of legitimacy.

\section{2) Benefits}

As noted the challenges of regionalism in the Pacific are vast, and very few scholars do not discuss them in the literature. Considering all of the challenges, one might wonder why there is still such a push to extend and improve these institutions. It could be argued that the answer to this question lies in the reason for the existence of regionalism itself. The Pacific Ocean contains thousands of small isolated islands, many of these are resource poor, and have capacity restraints throughout the public and private sector, as well as weak governance. Regionalism is used as a way to mitigate these constraints and use the similarities among the Pacific Islands to create positive pathways in development (Dornan \& Newton Cain, 2014, p. 1; Fry, 1994, p. 144). Ideally, regionalism could be used to create more choice, cheaper goods, more 
productive and healthier societies and more opportunities for citizens; this has often been canvassed in the literature (Asian Development Bank-Commonwealth Secretariat, 2005, p. xvii). One of the key arguments for Pacific Regionalism relates to Ratu Mara's concept of the 'Pacific Way' (Mara, 1997, p. 168). This concept believes that Pacific Islanders share a common sense of identity, and this 'cultural identity is a bond that brings Pacific Island countries and peoples together' (Huffer, 2006, p. 44). Beyond that, the concept is an argument against colonial rule, where Ratu Mara, Epeli Hau'ofa and many Pacific scholars believe in Pacific sovereignty and that Pacific Islanders need to stand up for their rights and take charge of their political systems (Mara, 1974, p. 2 in Fry, 2015, p. 4; Hau'ofa, 1994, p. 158). Hau'ofa, a former University of the South Pacific academic stated that 'although outsiders have had powerful influences on the Pacific, people have endured and been able to preserve tradition, identity and selfdetermination' quoted in (Momis, 1975, p. 81).

Another common argument for regionalism is that the Pacific Islands share strong commonalities, with not only similar histories, but challenges. Cooperation among states can allow the Pacific Islands to have access to technical assistance that would otherwise not be possible. The literature cites many good examples of this, including the University of the South Pacific that is an internationally recognised university that largely focusses on the Pacific context (Fry, 1994, p. 153). Collective diplomacy has also been a major benefit to help Pacific issues, a common example of this is the regional effort on ocean policy. Not only is ocean policy a transboundary issue, most of the Pacific shares a common stance and one unified Pacific voice has proven to be a lot stronger than one nation state (Frazer \& Bryant-Tokalau, 2006, p. 3). Conversely, a lot of the literature also points out that 'despite the fact that the Pacific is often classed as small and vulnerable, each state actually has varying economies and positions on international issues' (Fry, 1994, p. 168). Beyond these challenges, regionalism has the potential to strengthen individual states by providing them a louder voice, a platform for dialogue and the technical services to improve Pacific lives. 


\section{Section 3: The Gaps}

\section{Critical junctures, effective management, and legitimacy}

Finally in this section of the literature review, I will discuss the gaps in the literature and the scope of this research. One of the most interesting aspects of this topic is that constant discussion and analysis are required in order to make regionalism inclusive and truly effective. This thesis argues that although the literature covers a wide range of aspects and challenges to regionalism and its use in the Pacific, it does not focus enough on legitimacy. As stated in the global section, there is literature on the legitimacy of global governance institutions that explores very similar themes to challenges in regional institutions. In the literature on Pacific regionalism, Dornan and Newton Cain, Greg Fry, and Powell all mention the importance of legitimacy. Although these pieces of literature have different arguments to this research, they emphasise that a lack of legitimacy makes these institutions unsustainable and a considerable hurdle (Dornan \& Newton Cain, 2014, p. 15; Fry, 2015; Powell, 2005, p. 236). This research argues that these ideas correlate with regionalism, as without some form of legitimacy from Pacific people, Pacific regionalism cannot be effective or hold any power in decision-making. This absence of legitimacy creates a vicious cycle, where people do not trust the institutions, which in turn makes them more illegitimate and less effective.

This research will look at moments, or 'critical junctures' in history where Pacific states have banded together to alleviate challenges and find legitimacy in regionalism. Critical junctures are defined by Daron Acemoglu and James A. Robinson (2012, p. 101) as 'a major event or confluence of factors disrupting the existing economic or political balance in society'. In their book, Why Nations Fail Acemoglu and Robinson (2012) describe the way nations have formed and how institutions are developed over time. They use critical junctures as the reason why some nations have better conditions than others. They believe that this is because of institutions, and based on the moments in history where people have had the option to bargain for their rights and make their institutions more effective and less dependent, and therefore inclusive of real needs. Nations that have political and economic institutions that operate in the interest of the 
populous are more legitimate and people are more likely to claim ownership (Acemoglu \& Robinson, 2012). This area of literature has also been described further by the Development Leadership Program (2012) as a way to create effective coalitions. 'Coalitions are influenced by crises. Economic crisis can spur the creation of coalitions, though it may also serve as a catalyst for a coalition's demise. 'Critical junctures' or 'windows of opportunity' have often been seized to facilitate a reform initiative' (Development Leadership Program, 2012, p. 18). Analysing this idea in the Pacific regional context creates interesting parallels. Looking at moments of greatest unity (i.e. decolonisation, anti-nuclear testing, fishing policies, climate change, etc.) are when these institutions have been seen as the most effective (Fry, 1994, p. 160; Dornan \& Newton Cain, 2014, p. 13).

This research will suggest that a new form of legitimacy may be required. Drawing on Buchanan and Keohane's (2006) 'Complex Standard', the legitimacy of Pacific regional institutions will be analysed. Since the establishment of formalised regionalism in the Pacific, the nature of the game has changed. We are at a point in history where Pacific governments have more capacity to create change and form policy than ever before. With issues such as climate change drastically effecting Pacific islands, many Pacific leaders see this as an issue large powers need to address and not something that is associated with their national sovereignty (Fry, 1994, p. 160). With issues like this, that is where Pacific countries have come together with unified foreign policy agreement at the regional level. This research will claim that the issue of climate change has many parallels to the anti-nuclear Pacific movement from the 1970s. It is an issue that has been created by many of the region's allies (including one of its own members, Australia). Regionalism also is now being bombarded with new types of challenges and mechanisms, from Frank Bainimarama's Pacific Island Development Forum, the strong involvement of outsiders, such as the European Union, as well as sub-regionalism. Questions then arise: What does redefining legitimacy look like and how do we respond to these modern day challenges? One cannot deny that there have been great successes in Pacific regionalism, as mentioned earlier. But critical junctures cannot be made to order, just as legitimacy does not come from the simple existence or structure of a regional organisation. Regional organisations must be legitimate players in the 
regional and international arenas to achieve the success demanded of them. This thesis will examine how this legitimacy to be understood, derived, developed and strengthened in the current policy world.

CONTEXT:

THE BUREAUCRATIC DETAILS

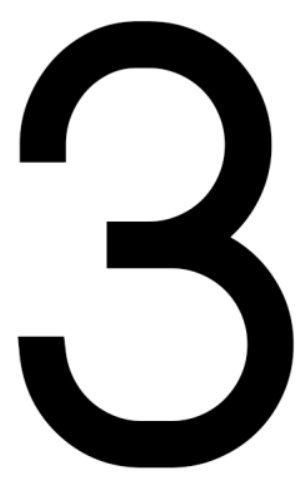


This short chapter aims to provide a foundation for the next chapters. It defines the two key institutions (SPC and PIFS) and highlights recent changes and events. This context will provide a deeper understanding of the way that these organisations operate and their purpose, as well as outline new strategies for more effective regionalism.

\section{Secretariat of the Pacific Community}

The original official regional institution in the Pacific was the South Pacific Commission. The purpose of this institution was set out in the very first meeting and formalised through the Canberra Agreement in 1947. This Agreement explains the priorities and business of the Commission. The participating members ${ }^{7}$ set out with the desire:

'...to encourage and strengthen international cooperation in promoting the economic and social welfare and advancement of the peoples of the non-selfgoverning territories in the South Pacific region administered by them...' Quoted in (Secretariat of the Pacific Community a, 2011, p. 1)

The basic purpose of the Commission was to provide a consultative and advisory body for Pacific Island states in order to promote positive development. It would provide the region with a technical services platform that would look at a range of issues affecting the Pacific. This included: agriculture, fisheries, communications, transport, forestry, industry, labour, marketing, production, trade and finance, public works, education, health, housing and social welfare. The Commission agreed to hold at least two regular sessions each year with the majority of participating governments, and a Conference every two years. The Agreement set out the location of the temporary Secretariat headquarters, funding arrangements, and its relationships with global institutions.

As the institution progressed and Pacific Island nations began to decolonise, the role of equal power between Pacific Island and metropolitan states came into question. In 1983, at the 23rd South Pacific Conference in Saipan, all Pacific Island nations were

\footnotetext{
${ }^{7}$ Participating members: American Samoa, Cook Islands, Federated States of Micronesia, Fiji, French Polynesia, Guam, Kiribati, Marshall Islands, Nauru, New Caledonia, Niue, Northern Mariana Islands, Palau, Papua New Guinea, Pitcairn Islands, Samoa, Solomon Islands, Tokelau, Tonga, Tuvalu, Vanuatu, and Wallis and Futuna, plus Australia, France, New Zealand and the United States of America. Former members: the Netherlands, the United Kingdom (Secretariat of the Pacific Community d, 2011) (Secretariat of the Pacific Community a, 2011)
} 
granted full voting rights to the Commission under the Saipan Decision. The original participating governments of the Commission changed over time as well, and now included many Pacific countries from the North and South of the region. In 1997 at the $50^{\text {th }}$ South Pacific Conference, the name of the institution was officially changed to the Secretariat of the Pacific Community (SPC).

The annual meeting is now known as The Committee of Representatives of Governments and Administrations (CRGA), and grants each participating member one vote in all proceedings. Every second year, the Conference is held, where ministers of the member states join to discuss regional issues. The institution brings together the Anglophone and Francophone sides of the Pacific, with both French and English used for meetings and documents (Secretariat of the Pacific Community a, 2011). The headquarters are based in Noumea, New Caledonia, with a regional office in Suva, Fiji (Secretariat of the Pacific Community b, 2011).

\section{Pacific Islands Forum Secretariat}

In the 1960s, many Pacific Island nations felt dominated by the colonial powers at the South Pacific Commission, as they did not have full voting status equal to the colonial countries. As the nation states became independent, leaders began to express their sovereignty and want a larger role in the region's decision making. The South Pacific Commission was a platform designed to target technical assistance, and did not have a focus on political issues. At the time, the French were conducting nuclear tests in the region and leaders were concerned about the potential hazards to the environment. It was however, not an issue that could be discussed openly and frankly at the South Pacific Commission, especially with France as a participating member.

As mentioned in the above, Prime Minister of Fiji Ratu Sir Kamasese Mara formed a new platform, the South Pacific Forum in 1971 (Frazer \& Bryant-Tokalau, 2006, p. 5). This new political body would concentrate on 'matters directly affecting the daily lives' of Pacific Islanders, and only include independent sovereign Pacific states (including Australia and New Zealand) (Pacific Islands Forum, 2005, p. 1 \& 4). The South Pacific Forum would operate alongside SPC and was not established to override their important work. The first Communiqué set out the priorities (trade, shipping, civil 
aviation, foreign investment and tourism, law of the sea, developments of oceanic resources, education, telecommunications, national parks, a regional disaster fund, joint diplomatic representation). It also outlined the prospect of an annual meeting of Leaders and set forward a premise for a 'frank and informal inter-change of views' (Pacific Islands Forum, 2005, pp. 1-4). Soon after the establishment, the meetings were formalised and an accompanying secretariat was created, the South Pacific Bureau for Economic Cooperation. In 1989, the name was officially changed to the Pacific Islands Forum and the Pacific Islands Forum Secretariat (Frazer \& Bryant-Tokalau, 2006, p. 6).

The two main priorities of the Forum were to respect national sovereignty and promote economic development. During this time the Forum entered into many trade agreements (e.g. the South Pacific Regional Trade and Economic Cooperation Agreement within the region and the Lomé Agreement between Europe and African, Caribbean and Pacific (ACP) counties). Many more regional bodies were established over this period, with the goal of 'functional cooperation', the key bodies eventually joined to make up the Council for Regional Organisations in the Pacific (CROP) (See Figure $2 \&$ Figure 3). These new bodies gave Pacific nations the opportunity to be involved in international affairs, particularly in regard to fisheries policy and nuclear testing (Frazer \& Bryant-Tokalau, 2006, p. 7).

Although the purpose of the Pacific Islands Forum has changed significantly over time, there is a current non-binding treaty between the member states. The 2005 Agreement Establishing the Pacific Islands Forum sets out the main goals for the body, outlines the business side of the meetings and the Secretariat (see Figure 2). The Forum Leaders' Meeting is the main conference that is held annually. The location for the meeting rotates each year to a different member country. The hosting country is also the chair of all Forum meetings until the next conference. The leaders usually also meet annually for a special meeting or Retreat to discuss the upcoming Forum and any other issues that have arisen over the year. There are also annual meetings for government ministers, for example the Forum Economic Ministers Meeting (FEMM), but also other sectors such as trade, education and foreign affairs (Peebles, 2005, p. 59). For all general policy decisions, the Pacific Islands Forum Officials' Committee (FOC) will meet at least once a year. This Committee is comprised of senior officials from 
each government and determine much of the daily business of the Secretariat (e.g. budget) and the agenda items for the Forum Leaders' Meetings. From my experience at PIFS, in practice, this meeting is now held twice a year: one pre-Forum, and one budget and work plan. As part of the Pacific Islands Forum Secretariat, the Secretary General plays the role as the Chief Executive Officer and reports directly to the Leaders (Pacific Islands Forum, 2005). The Secretary General holds the coordination role for the CROP agencies and working groups, the Secretariat also provides any additional support (Pacific Islands Forum Secretariat b, n.d.). The Secretariat itself is primarily responsible for implementing directives from the Leaders' Meetings, as well as policy advice and coordination (Pacific Islands Forum, 2005).

\section{Council of Regional Organisations in the Pacific (CROP) Agencies}

The Secretariat of the Pacific Community and the Pacific Islands Forum Secretariat are members of the CROP (see Figure $2 \& 3$ ). The main outcome of CROP is to ensure that there is harmonisation and mutual support through all regional initiatives. The CROP is a high-level advisory body made up of ten inter-governmental organisations focussed on varying Pacific regional challenges and sectors. Parts of the CROP meet regularly in working groups to cooperate on different issues, as well as regular CROP heads meetings where the chief executives meet (Pacific Islands Forum Secretariat b, n.d.).

\section{Pacific Plan}

In 2003 at the Pacific Islands Forum Special Leaders' Retreat in Auckland, Pacific Leaders came together to create a new vision for Pacific regionalism. This reevaluation of the role of the Pacific Islands Forum and Pacific regionalism was a reaction to new challenges impacting the region and the Forum's capability to meet them. The leaders adopted the Auckland Declaration in 2004 which set out a modern vision explaining the approach of the Forum and its role in the region. Most importantly, it outlined the development of a 'Pacific Plan'. This would involve a review of the Forum and its Secretariat, and a coordinated effort to make regionalism more effective and coordinated (Pacific Islands Forum, 2004) (Peebles, 2005, p. 5). The Eminent Persons Group (EPG) was set up and then spent six months at the Pacific Islands Forum Secretariat carrying out the review. They presented a report, 'Pacific 
Cooperation Voices of the Region', at the 2004 Leaders Meeting. In the coming months, four pillars were set up by the Forum: security, good governance, economic growth and sustainable development. The next steps involved the creation of a Pacific Plan that would put forward a framework to improve regional architecture and processes (Frazer \& Bryant-Tokalau, 2006, p. 21; Goff, 2006, p. 29; Pacific Islands Forum Secretariat, 2014, p. 11).

The Pacific Plan was drafted based on the four pillars. It outlined how the goals were interpreted by the leaders, as well as defined the concept of regionalism and its different types. This new Pacific regionalism would be inclusive and bring together member states, civil society, private sector and development partners. It outlined immediate implementation plans for each goal, and provided a thorough implementation plan for the next three years in the Attachment section at the end of the document. Most importantly, the Pacific Plan was designed to strengthen regional cooperation and improve Pacific lives (Pacific Islands Forum Secretariat, 2007).

Although the Pacific Plan created a lot of excitement within both politics and academia, there was much criticism. Most commonly, it was suggested that the Plan was too vague. Critics (for example: (Hughes, 2013; Dornan \& Newton Cain, 2014, p. 8; Dornan, 2014)) stated that the Plan lacked ownership and that the purpose required further clarity. The Pacific Plan covered a huge number of challenges, and this made the agreements very broad. Many believed that this was just another attempt to restructure the Secretariat, and was not going to create effective and coordinated results. As Seini O'Connor, the former Pacific Plan Adviser at the Pacific Islands Forum Secretariat, stated 'beyond the talking, though, people might rightly wonder: what work is being done? There are expectations that regionalism should bring not only resolutions, but new services and facilities visible on the ground' (O'Connor, 2014).

Concerns over a seeming 'lack of concrete outcomes' from this diffuse Plan and a recognition that you cannot have one development plan for the entire region, it was agreed in 2013 that a review of the Plan should be undertaken. The nature of the Pacific Plan meant that the Pacific Plan Review Team, headed by former Papua New Guinea Prime Minister Sir Mekere Morauta, would take criticisms on board to adopt an inclusive framework. In 2013, the Pacific Plan Team took in public submissions with 
suggestions on how the Plan could be improved. This resulted in the Pacific Plan Review 2013, a new approach to effective regional coordination. Instead of creating a long "wish list" of priorities to guide funding and overloading the Leaders with a huge range of priorities, the Review looked at creating a new public policy process to determine the most relevant agenda items for Leaders' consideration. Importantly, the new process aimed to strengthen the mandate of the other component parts of the regional architecture by requesting CROP agency governing bodies to make decisions on matters appropriate to their mandate rather than continually pushing all decisions to Leaders. Leaders need only consider the issues that required their political weight and power to unlock. This was decided to avoid duplication at the national level, as well as among other regional institutions. It also allowed for the leaders to look at a few most pressing issues more in depth, and ensure a more focused Forum agenda. However, 'in reality, it won't be the document that delivers: it will be the officials and decision-makers who use it guide their work' (O'Connor, 2014).

\section{Framework for Pacific Regionalism}

As a result of the Pacific Plan Review 2013, the Framework for Pacific Regionalism was created. It replaced the Pacific Plan and focussed on reducing the number of items on the agenda of the Forum Leaders' Meetings. Although matters arising from trade negotiations and ministerial meetings can make their way onto the agenda, the Framework ensures that a select number of priority issues (no more than five) are identified through an inclusive process (including private sector and civil society) and will be included on the agenda. It also aims to provide a more inclusive approach to regionalism and broaden the conversation to CROP agencies, the public, civil society, private sector, partners and academia. It also had a strong focus on emphasising the political nature of regionalism. The Framework sets out a timeline of operation for the Framework (see Appendix 1). The Secretariat made a call for public proposals on regional initiatives, these were assessed by the Specialist Sub-Committee on Regionalism (made up of a representative of the range of countries and stakeholders). The best proposals were selected by the Sub-Committee based on tests set out in the Framework and passed on to the FOC. The proposals were then commented on at FOC and placed on the agenda for the $46^{\text {th }}$ Pacific Islands Leaders' Meeting (Dornan \& 
Newton Cain, 2014). Although the Framework has flexible provisions, a similar process will be used every year to determine inclusive priority issues (Pacific Islands Forum Secretariat, 2014).

\section{Recent events}

In early 2014, the Forum Leaders appointed a new Secretary General (SG), Dame Meg Taylor of Papua New Guinea. Dame Meg Taylor has served as a Papua New Guinean diplomat in the past and also served 15 years as a Vice President and Compliance Advisor Ombudsman (CAO) of the World Bank Group (Pacific Islands Forum Secretariat c, n.d.). As the Framework for Pacific Regionalism was endorsed by Leaders at the beginning of her tenure, it has been the guiding vision of her leadership. The appointment of a new Secretary General at this time could be considered as an important critical juncture in the Forum's history (Dornan \& Newton Cain, 2014).

In September 2015, the $46^{\text {th }}$ Pacific Islands Leaders' Meeting was held in Port Moresby, Papua New Guinea. This was the first test for the implementation of the Framework for Pacific Regionalism. It brought forward many of the more complex issues of the region, such as climate change and concern for human rights violations in West Papua (Dornan \& Newton Cain, 2014). The Leaders endorsed the Hiri Declaration "Strengthening Connections to Enhance Pacific Regionalism" which replaces the Auckland Declaration. The Hiri Declaration is designed to be the guiding statement for the Forum that complements the Framework, and highlights the key challenges ahead (especially political) (Pacific Islands Forum b, 2015; Pacific Islands Forum a, 2015). There is much enthusiasm about the potential for regional cooperation. The next few years will play an interesting role in determining whether it will promote pathway for effective development, or see its high ideals 'lost in translation' - as one Leader lamented of its predecessor. 
Figure 2: Structure of the Pacific Islands Forum Secretariat

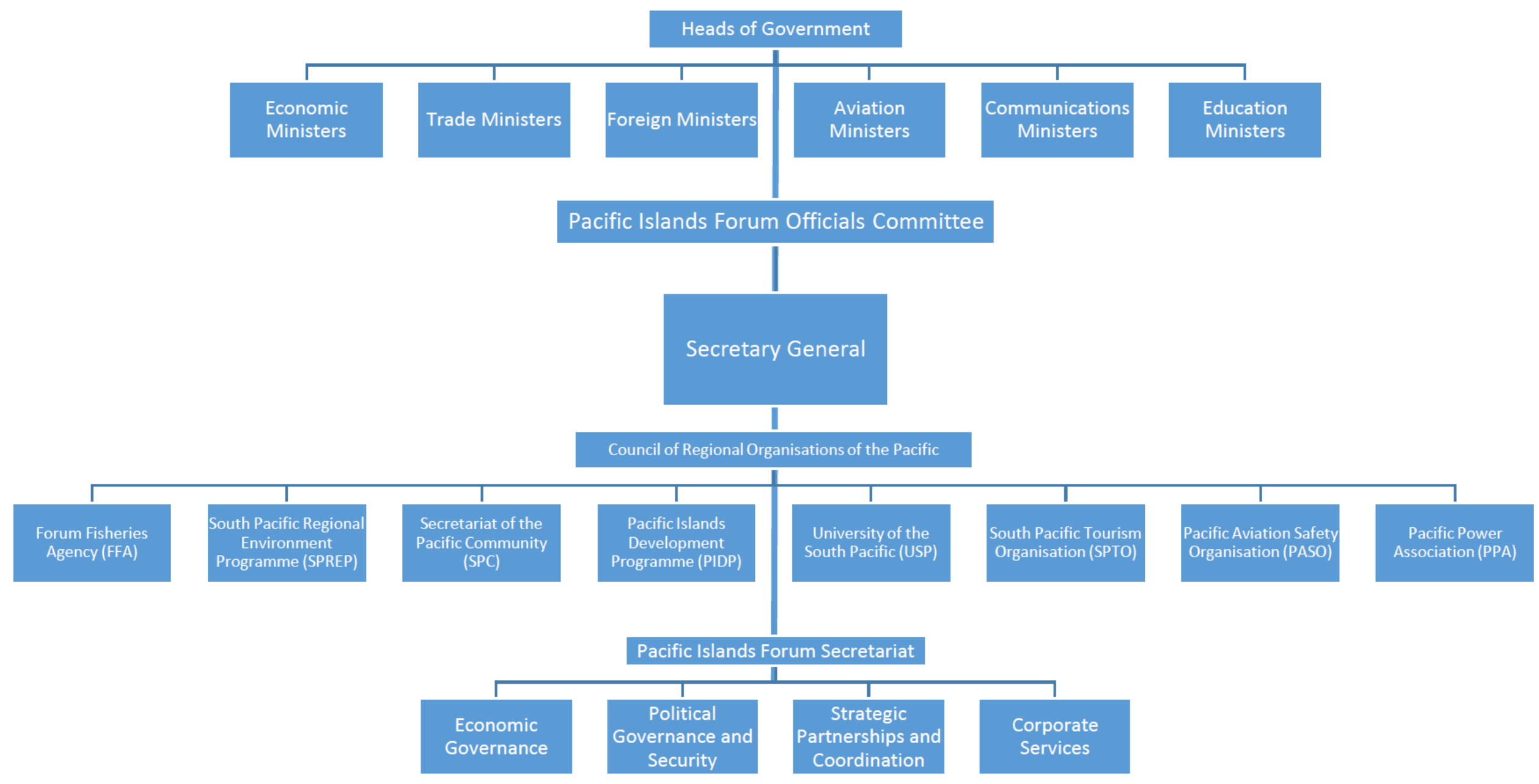

Source: Peebles, 2005, p. 61, Pacific Islands Forum Secretariat, n.d. 
Figure 3: Council of Regional Organisations in the Pacific (CROP) Agencies

\begin{tabular}{|c|c|c|c|c|}
\hline $\begin{array}{l}\text { Name of Regional } \\
\text { Institution }\end{array}$ & $\begin{array}{l}\text { Year } \\
\text { Established }\end{array}$ & Headquarters & Members & Function \\
\hline $\begin{array}{l}\text { Forum Fisheries } \text { Agency } \\
\text { (FFA) }\end{array}$ & 1979 & $\begin{array}{l}\text { Honiara, } \\
\text { Solomon } \\
\text { Islands }\end{array}$ & $\begin{array}{l}\text { Australia, Cook Islands, Federated States of } \\
\text { Micronesia, Fiji, Kiribati, Marshall Islands, } \\
\text { Nauru, New Zealand, Niue, Palau, Papua New } \\
\text { Guinea, Samoa, Solomon Islands, Tokelau, } \\
\text { Tonga, Tuvalu, and Vanuatu }\end{array}$ & $\begin{array}{l}\text { Helps manage, control and develop } \\
\text { Pacific fishery resources (particularly } \\
\text { tuna stock) (Pacific Islands Forum } \\
\text { Fisheries Agency, 2015). }\end{array}$ \\
\hline $\begin{array}{l}\text { Pacific Aviation Safety } \\
\text { Organisation (PASO) }\end{array}$ & 2005 & $\begin{array}{ll}\text { Port } & \text { Vila, } \\
\text { Vanuatu } & \end{array}$ & $\begin{array}{l}\text { Cook Islands, Kiribati, Niue, Nauru, Papua New } \\
\text { Guinea, Samoa, Solomon Islands, Tonga, } \\
\text { Tuvalu, and Vanuatu. } \\
\text { Countries which are also members of PASO, } \\
\text { but not Parties to the Pacific Islands Civil } \\
\text { Aviation Safety and Security Treaty (PICASST) } \\
\text { are: Australia, New Zealand and Fiji. }\end{array}$ & $\begin{array}{l}\text { Oversees aviation safety and } \\
\text { security in the Pacific in accordance } \\
\text { with the guidelines of the } \\
\text { International Civil Aviation } \\
\text { Organization (ICAO) (Pacific Aviation } \\
\text { Safety Office, 2014). }\end{array}$ \\
\hline $\begin{array}{lr}\text { Pacific } & \text { Islands } \\
\text { Development } & \text { Programme } \\
\text { (PIDP) } & \end{array}$ & 1980 & $\begin{array}{l}\text { Honolulu, } \\
\text { Hawai'i }\end{array}$ & $\begin{array}{l}\text { Pacific Island Conference members: American } \\
\text { Samoa, Cook Islands, Federated States of } \\
\text { Micronesia, Fiji Islands, French Polynesia, } \\
\text { Guam, Hawai'i, Kiribati, Marshall Islands, } \\
\text { Republic of the Nauru, New Caledonia, Niue, } \\
\text { Northern Mariana Islands, Commonwealth of } \\
\text { the } \\
\text { Palau, Papua New Guinea, Samoa, Solomon } \\
\text { Islands, Tonga, Tuvalu, and Vanuatu }\end{array}$ & $\begin{array}{l}\text { Assist Pacific Island leaders to } \\
\text { advance and sustain social and } \\
\text { economic development (East-West } \\
\text { Center, n.d.). }\end{array}$ \\
\hline $\begin{array}{l}\text { Pacific Islands Forum (PIF) } \\
\text { \& Pacific Islands Forum } \\
\text { Secretariat (PIFS) }\end{array}$ & $\begin{array}{l}1971 \quad \text { (as } \\
\text { South Pacific } \\
\text { Forum) }\end{array}$ & Suva, Fiji & $\begin{array}{l}\text { Australia, Cook Islands, Federated States of } \\
\text { Micronesia, Fiji, Kiribati, Nauru, New Zealand, } \\
\text { Niue, Palau, Papua New Guinea, Republic of } \\
\text { Marshall Islands, Samoa, Solomon Islands, } \\
\text { Tonga, Tuvalu and Vanuatu. } \\
\text { Associate Membership: New Caledonia and } \\
\text { French Polynesia. }\end{array}$ & $\begin{array}{l}\text { The region's principal policy } \\
\text { platform/meeting for leaders and } \\
\text { institution that establishes a } \\
\text { collective regional agenda (Pacific } \\
\text { Islands Forum Secretariat a, n.d.) }\end{array}$ \\
\hline
\end{tabular}




\begin{tabular}{|c|c|c|c|}
\hline & & $\begin{array}{l}\text { Current Forum Observers include: Wallis } \\
\text { and Futuna, the Commonwealth, the United } \\
\text { Nations, the Asian Development } \\
\text { Bank, Western and Central Pacific Fisheries } \\
\text { Commission, the World Bank, the ACP Group, } \\
\text { American Samoa, Guam and the } \\
\text { Commonwealth of the Northern Marianas, } \\
\text { and the International Organization for } \\
\text { Migration. } \\
\text { Special Observer: Timor Leste. }\end{array}$ & \\
\hline $\begin{array}{l}\text { Pacific Power Association } \\
\text { (PPA) }\end{array}$ & Suva, Fiji & $\begin{array}{l}\text { American Samoa Power Authority (American } \\
\text { Samoa), Chuuk Public Utility Corporation } \\
\text { (Chuuk State, Federated States of Micronesia), } \\
\text { Commonwealth Utilities Corporation } \\
\text { (Commonwealth of Northern Marianas), } \\
\text { Electric Power Corporation (Samoa), Électricité } \\
\text { de Tahiti (French Polynesia), Électricité et Eau } \\
\text { de Caledonie (New Caledonia), Électricité et } \\
\text { Eau deWallis et Futuna (Wallis \& Futuna), } \\
\text { Enercal (New Caledonia), Fiji Electricity } \\
\text { Authority (Fiji), Guam Power Authority } \\
\text { (Guam), Kosrae Utility Authority (Kosrae State, } \\
\text { Federated States of Micronesia), Kwajalein } \\
\text { Atoll Joint Utility Resource (Ebeye, Republic of } \\
\text { Marshall Islands), Marshalls Energy Company } \\
\text { (Republic of Marshall Islands), Niue Power } \\
\text { Corporation (Niue), Nauru Utilities Authority } \\
\text { (Nauru). Palau Public Utilities Corporation } \\
\text { (Palau). PNG Power Limited (Papua New } \\
\text { Guinea), Pohnpei Utility Corporation (Pohnpei } \\
\text { State, Federated States of Micronesia), Public } \\
\text { Utilities Board (Kiribati), Solomon Islands } \\
\text { Electricity Authority (Solomon Islands), Te }\end{array}$ & $\begin{array}{l}\text { 'Promotes the direct cooperation of } \\
\text { the Pacific island power utilities in } \\
\text { technical training, exchange of } \\
\text { information, sharing of senior } \\
\text { management and engineering } \\
\text { expertise' (Pacific } \\
\text { Association, 2012). Power }\end{array}$ \\
\hline
\end{tabular}




\begin{tabular}{|c|c|c|c|c|}
\hline & & & $\begin{array}{l}\text { Aponga Uira O Tumu-Te-Varovaro (Cook } \\
\text { Islands), Tonga Power Limited (Tonga), Tuvalu } \\
\text { Electricity Corporation (Tuvalu), UNELCO } \\
\text { Vanuatu Limited (Vanuatu), Yap State Public } \\
\text { Service Corporation (Yap State, Federated } \\
\text { States of Micronesia). }\end{array}$ & \\
\hline $\begin{array}{l}\text { Secretariat of the Pacific } \\
\text { Community (SPC) }\end{array}$ & $\begin{array}{|lr|}1947 \quad \text { (as } \\
\text { South } & \text { Pacific } \\
\text { Community) }\end{array}$ & $\begin{array}{l}\text { Noumea, New } \\
\text { Caledonia }\end{array}$ & $\begin{array}{l}\text { American Samoa, Cook Islands, Federated } \\
\text { States of Micronesia, Fiji, French Polynesia, } \\
\text { Guam, Kiribati, Marshall Islands, Nauru, New } \\
\text { Caledonia, Niue, Northern Mariana Islands, } \\
\text { Palau, Papua New Guinea, Pitcairn Islands, } \\
\text { Samoa, Solomon Islands, Tokelau, Tonga, } \\
\text { Tuvalu, Vanuatu, and Wallis and Futuna, plus } \\
\text { Australia, France, New Zealand and the United } \\
\text { States of America. }\end{array}$ & $\begin{array}{l}\text { A non-political organisation that } \\
\text { provides technical services, policy } \\
\text { advice, research and training to the } \\
\text { region. There are programmes in a } \\
\text { wide range of sectors, including } \\
\text { economic and social development, } \\
\text { public health, fisheries, land } \\
\text { resources, statistics, and geoscience } \\
\text { (Secretariat of the Pacific } \\
\text { Community a, 2011). }\end{array}$ \\
\hline 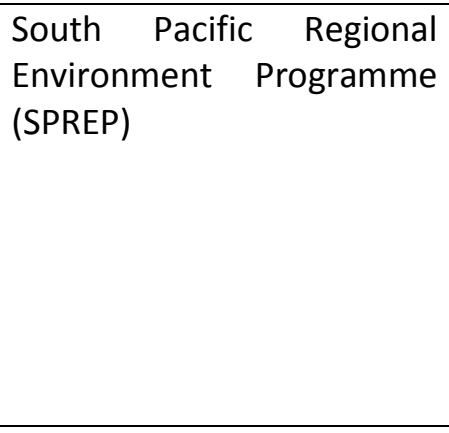 & $\begin{array}{l}1993 \\
\text { (autonomous } \\
\text { agency); } \\
1970 \text { s (as } \\
\text { part of SPC) }\end{array}$ & Apia, Samoa & $\begin{array}{l}\text { American Samoa, Australia, Commonwealth of } \\
\text { the Northern Mariana Islands, Cook Islands, } \\
\text { Federated States of Micronesia, Fiji, France, } \\
\text { French Polynesia, Guam, Kiribati, Marshall } \\
\text { Islands, Nauru, New Caledonia, New Zealand, } \\
\text { Niue, Palau, Papua New Guinea, Samoa, } \\
\text { Solomon Islands, Tokelau, Tonga, Tuvalu, } \\
\text { United Kingdom, United States of America, } \\
\text { Vanuatu and Wallis and Futuna. }\end{array}$ & $\begin{array}{l}\text { Promote regional cooperation in } \\
\text { environmental issues, with strategic } \\
\text { priorities in biodiversity and } \\
\text { ecosystem management, climate } \\
\text { change, environmental monitoring } \\
\text { and governance, and waste } \\
\text { management and pollution contro } \\
\text { (Secretariat of the Pacific Regiona } \\
\text { Environment Programme, 2014). }\end{array}$ \\
\hline $\begin{array}{l}\text { South Pacific } \\
\text { Organisation (SPTO) }\end{array}$ & 1983 & Suva, Fiji & $\begin{array}{l}\text { American Samoa, Cook Islands, Federated } \\
\text { States of Micronesia, Fiji, Kiribati, Marshall } \\
\text { Islands, Nauru, New Caledonia, Niue, Palau, } \\
\text { Papua New Guinea, Samoa, Solomon Islands, } \\
\text { Tahiti, Timor Leste, Tonga, Tuvalu, and } \\
\text { Vanuatu }\end{array}$ & $\begin{array}{l}\text { Intergovernmental body with the } \\
\text { mission to promote, market and } \\
\text { develop tourism in the Pacific (South } \\
\text { Pacific Tourism Organisation, n.d.). }\end{array}$ \\
\hline $\begin{array}{l}\text { University of the South } \\
\text { Pacific (USP) }\end{array}$ & 1968 & Suva, Fiji & $\begin{array}{l}\text { Cook Islands, Fiji, Kiribati, Marshall Islands, } \\
\text { Nauru, Niue, Solomon Islands, Tokelau, Tonga, }\end{array}$ & $\begin{array}{l}\text { Regional tertiary (undergraduate } \\
\text { and post graduate levels) institution }\end{array}$ \\
\hline
\end{tabular}




\begin{tabular}{|l|l|l|l|}
\hline & & Tuvalu, Vanuatu and Samoa & $\begin{array}{l}\text { in the Pacific with campuses in all } \\
\text { member countries. The university } \\
\text { has faculties in: Arts, Law and } \\
\text { Education; Business and Economics; } \\
\text { and Science, Technology and } \\
\text { Environment (University of the } \\
\text { South Pacific, 2013). }\end{array}$ \\
\hline
\end{tabular}


METHODOLOGY:

THE THEORIES AND THE WAYS

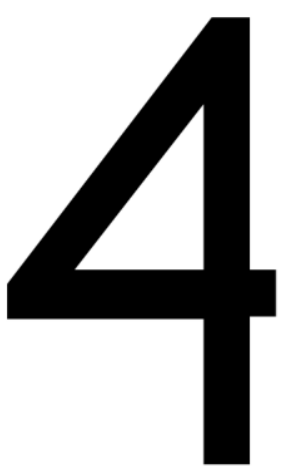

This chapter will discuss and analyse my methodology and methods. The aim of the chapter is to highlight my chosen framework, epistemology and methods of research. I will begin by discussing the inductive approach, then introduce my epistemology and positionality. Each of these will be analysed for their benefits and disadvantages, as well as their usefulness to the research project. I will then discuss my chosen methods and my choice to use qualitative data. Finally it will reflect on my experiences of the research project: power relations, limitations and other observations throughout the process.

\section{Inductive approach}

This research utilises an inductive approach, where the new information and data collected will be used to observe and build upon a new theory and evidence (see Figure 4). As there is no theory that completely fits into this project, it will be important to look at a broader approach outside of the Pacific, in order to be able to bring experience into the regional agenda. Unlike a deductive approach that aims to test hypothesises, this research project will use a range of methods in order to make observations and create new theories (Stewart-Withers, et al., 2014, p. 59). As Flick (2009, p. 12) wrote:

'rapid social change and the resulting diversification of life worlds are increasingly confronting social researchers with new social contexts and perspectives. These are so new for them that their traditional deductive methodologies... are failing due to the differentiation of objects. Thus, research is increasingly forced to make use of inductive strategies'. 
Upon reflection, Flick's statement aligns well with my research project, as it observes people, history and critical thought to produce findings. The inductive approach fits well with qualitative research methods, as it focusses on finding the nature of understanding' and observing local knowledge and practices (Bryman and Burgess, 1999 in Stewart-Withers, et al., 2014, p. 59) (Flick, 2009, p. 12). As Hoepfl (1997, p.13 in Stewart-Withers, et al., 2014, p. 59) stated, 'where quantitative researchers seek casual determination, predication, and generalisation of findings, qualitative researchers seek instead illumination, understanding, and extrapolation to similar situations'. I believe that keeping an open mind and allowing myself to explore different ideas created a more interesting research journey and outcome. However it must be noted that there are limitations to this approach and it is impossible to have a completely open mind. My interest in taking on this particular research project was sparked by the fact that I could not predict a possible outcome. Prior to conducting my research, I had experience with Pacific regional institutions and I began writing my literature review at the start of the research process. The concept of my personal bias is discussed further in my positionality section.

\section{Epistemology: social constructivism}

This research project claims that knowledge is constructed and socially contingent. It uses the epistemology of social constructivism to interpret how people make change and legitimise Pacific regionalism. Social constructivism takes the view that meanings are varied and complex, and that it is too difficult to create one truth of reality. This epistemology assumes that 'realities exist in the form of multiple mental constructions, socially and experientially based, local and specific, dependent for their form and content on the persons who hold them' (Lincoln, et al., 2011, p. 102). Each person has a different world view and experiences, and these shape our decisions and relationships. This epistemology aligns well with my research as it is people who are the decision-makers and shakers of Pacific regional policy. It is their experience and bias that shapes the political environment, and has the potential to create change. As it takes the view that as the researcher I will be observing informants' socially constructed meanings and therefore have aimed to create a theory through an inductive approach (Creswell, 2003, pp. 8-9). As this epistemology relies so heavily on 
people's views, open-ended and semi-structured interviews will be used so that the informants can construct their own meanings (Creswell, 2003, p. 8). Furthermore it recognises the role of the researcher, and as Flax stated 'we cannot know the real without recognising our own role as knowers' (Flax, 1990). Through the inductive approach, this research project has aimed to take an open-minded approach and therefore it is important that I understand my role in the research. Not only was it important for me to observe the knowledge of the informants and literature, but to be reflexive about my own biases and influence over ideas. Considering my own positionality - my world view, experiences, culture, demographics, etc. - is a vital part of my epistemology (Creswell, 2003, p. 9) (Lincoln, et al., 2011, p. 104).

\section{Positionality}

I recognise that my role in this research has shaped outcomes and perspectives. I believe that by identifying my role, being explicit about my positionality, as well as through constant reflexivity, this mitigates some of the limitations of being completely open-minded. This openness gives the reader a chance to consider my perspective and the way that I have approached the research. It would be unrealistic to state that I am a completely unbiased observer with no influence over this research project. Prior to starting my master's degree at the Victoria University of Wellington (VUW), I held an internship at the Pacific Islands Forum Secretariat, one of the key organisations analysed in this research project. I only recently finished an eight month internship with the New Zealand Ministry of Foreign Affairs and Trade in the New Zealand Aid Programme, during which time I worked with the Kiribati, Samoa and Vanuatu programme teams in the Pacific Development Division. Beyond this, my father is a retired senior development practitioner for the Australian Aid Program and up until recently was based in Suva, Fiji. His last position as Minister Counsellor was responsible for bilateral aid programmes in the majority of the Pacific, as well as Australia's role in regional organisations. He often sat in the chair as the Australian representative at large regional meetings and has sat on recent interview panels for high-level regional positions. As a result of my father's work I grew up predominantly in the Pacific: in Fiji, Papua New Guinea and Tonga, as well as Australia and the United States. In the context of social class, due to my father's reputation and position, as well 
as having been an expatriate living in the Pacific, I am most likely to be considered part of the upper-middle class. My life has constantly been surrounded by development work and I believe that in many ways my experience has been hugely beneficial to my research topic. Within the interview process, the connections that I have formed through my previous experiences were crucial to getting in contact with the relevant informants. Perhaps the interviews would not have been at all possible without my personal connections and experiences. I do, however, understand the role my bias, particularly as an Australian, has played in the research process. Furthermore it may also be worth noting that I am a Caucasian female in her early twenties with a Bachelor of Arts in International Studies (majors in Spanish Language, and Politics and Government). It also could be said that by using an inductive socially constructed approach I am creating a research project that is too dependent on my own experience. Furthermore my history, skills and creativity could all be considered limiting factors of this research project. Through the recognition of my biases, my positionality is part of what separates this research topic from other literature and makes it unique. It allows my own insight into the topic and uses my experiences to develop ideas and world view (Stewart-Withers, et al., 2014, p. 59). I recognise myself as a learner and observer, and not an expert or someone who is quick to judge. My awareness of my role and how my actions influenced the research is vital (Stewart-Withers, et al., 2014, p. 61).

\section{Methods: qualitative data}

For this research project, I have used a qualitative research methodology. Qualitative research was chosen as it allows for flexibility and gives the participants and researcher the opportunity to shape the responses to their own social construction. It produces unique results and unexpected insights. It aligns well with my epistemology, as it analyses social processes, history and relationships (Barbour, 2008). Furthermore, as the inductive approach is being utilised, it helps generate answers from an open mind; it is not tied to a 'fixed hypothesis' (Stewart-Withers, et al., 2014, p. 61). Regional policy is made through the decision-making of people, and their ideas are diverse. It looks at the different relationships between people and context to create 'rich, thick descriptions' (Stewart-Withers, et al., 2014, p. 61). As mentioned in the conceptual framework (Figure 4), this research project has used three types of 
qualitative data to generate findings, these are: interviews; exploration of historical documents; analysis of literature.

\section{Interviews}

The research used in-depth interviews with key informants as the central method. The style of interviews used were semi-structured and conversational. This allowed for the participant to choose their own focus and elaborate on components they found important. Upon selecting who to interview, I decided that I wanted to speak with high-level officials from Pacific Regional organisations (SPC and PIFS). In order to get a more diverse range of participants, I also included other stakeholders involved in decision-making, such as civil society, sceptics, academics and former decision-makers. I ensured that my sample had a mix of Pacific Islanders and other stakeholders, and there was a balance among the gender of participants. The resulting eight interviews asked questions about the usefulness of Pacific Regional organisations, how they form their legitimacy, how collective action is encouraged, as well target some of the key critiques within the literature. These interviews were conducted via audio-visual, telephone or by email response, due to constraints of remoteness in the Pacific region and research budget. The option of email was offered as many of the participants are busy people in very important positions. In some cases, the email responses required further clarification and follow up emails were sent. The process of recruiting participants was via email. The emails included six questions, VUW human ethics forms and information about my research project (see Appendix 2).

List of participants:

- Alan Morris, former senior Australia public servant, consultant, worked on policy at SPC and PIFS

- Dame Meg Taylor, Secretary General of the Pacific Islands Forum Secretariat

- Dr Matthew Dornan, academic at the Australian National University

- Dr Tess Newton Cain, consultant, Dev Policy Blog writer on Pacific regional affairs

- Greg Fry, academic at the University of the South Pacific 
- Peter Bazeley, consultant, worked on Pacific Plan Review team, and policy of SPC and PIFS

- Soli Middleby, former Australian aid official, worked on Pacific regionalism

- One other participant who chose to remain anonymous.

Within academia, a small amount of research has been completed on the methodological challenges of interviewing elites. The term elites is static, but is usually understood to mean people who hold strategic positions or are key informants in the field. It is often difficult to gain access to these elites, let alone secure an interview (Dexter, 1970; McDowell 1998; Ostrander, 1993 in Harvey, 2010, p. 203). William S. Harvey stated that 'researchers should try and pursue as many avenues as possible, including their own social networks' (Harvey, 2010, p. 203). He believes that the researcher's positionality and affiliations 'may affect their ability to gain access to elite members'. Securing interviews with elites can be quite difficult, but it also is an efficient and effective way to gain insights into the internal affairs of organisations.

\section{Historical documents and literature}

The other form of research I analysed involved historical documents and literature. In the case of historical documents, this method was chosen in order to examine the foundations of Pacific regional institutions and their present aims and outcomes. They provide an analysis of policy documents over the past 70 years and will relate to the broad political and economic context. These documents included: Pacific Plan papers, communiqués from past SPC and PIFS conferences, the organisations' annual reports, foundation papers, as well as news articles and academic commentaries. The other method was an analysis of literature and the broader context based on regionalism, legitimacy and sovereignty. This particular outlook was chosen as global trends have strongly influenced the Pacific regional experience, and give an interesting insight to determine if successes of other regions is transferable to Oceania. The literature also provides recounts of critical junctures and challenges over time, as well as an academic view of when regionalism has proven to be most legitimate in the Pacific. These methods were chosen as an alternative way bring light to why these organisations were originally established, the changing social constructions over time and its 
relevance in the modern day. They were chosen to compliment the interviews, but also provide analysis from a more diverse range of responses. My method of analysing the available documents started with reading prominent literature on regionalism and any available literature on Pacific regionalism. This process helped build my literature review and create themes that I would explore through more thorough document analysis and interviews. It helped me generate themes and key questions that I could keep in mind throughout my research. I chose the process of content analysis in order to review and include relevant quotes or passages in my findings. See Figure 5 for the Document Analysis Sample.

\section{Reflection}

As part of my social constructivist epistemology, it is important for me to provide reflections of the research project and explain some of the key limitations. Research rarely goes exactly according to plan, and there were many different hurdles along the way. Although there are limitations to this research project, many still have positive or interesting outcomes.

\section{Power relations}

Power relations between myself as the researcher and my interview participants as regional elites was a concern to my work. It was difficult to get in contact with some of the people I wished to interview, or others were not interested in investing in a master's thesis. Although my father did not directly help me recruit participants, in almost all of the interviews his name and work was mentioned. I think that in many ways this was actually a benefit because people understood that I had the background knowledge, and through our social connection were more willing to provide frank and open responses. I was not able to recruit many participants with a background at the Pacific Community, so the research project is much more focussed on the Forum. I did think this was a limitation at first, but I think that as the Framework for Pacific Regionalism being centred on the Forum and the Secretariat, much of the dialogue also has this focus. Another limitation was the lack of Pacific Island voices in my interviews. This was partly due to the participants who agreed to take part in the research, as not everyone I contacted responded. Originally I made a concerted effort 
to ensure that my sample would be balanced. I think the imbalance was also due to my connections and networks as an expatriate. The sample that I interviewed were also key informants, with very extensive experience working within the Pacific region. Although I recognise this as a limitation, many of the participants have spent large periods of their career living and working in the Pacific region.

\section{Research methods}

The interviews worked really well, especially since I already knew most of my participants. In choosing to do phone, audio-visual and email interviews, there was a sense that I had selected the second best option. On reflection though, I do not think that interviewing people in person would have made much of a difference. By using this method, I was able to talk to people from all over the region, and the world (Fiji, Vanuatu, Australia, and the United Kingdom). Instead of selecting people who were all in one place (i.e. Suva) I was able to get a more diverse sample and select the top participants in the field. I think that by providing participants with a guide to the questions beforehand made the process much easier to discuss over the phone. Participants were able to get a good idea of my research project and prepare their responses beforehand. There could also be limitations found in my sample size which was very small (eight). However, each participants was carefully chosen in order to ensure that they would provide a wide variety of responses and experiences. Also by using my literature review and document analysis as secondary methods, I was able to achieve a broader response. Another limitation could be the questions that I chose, and how they were worded. This was mitigated by letting all participants know that the interviews were flexible, and by allowing them to make additional comments at the end of the interview if something was not mentioned or highlighted. The flexibility also meant that participants had the option to respond via phone or email. This meant that the length of the responses varied. As all of the interview respondents were very busy people, I think that if I had not made this flexibility available, I would not have received any responses. Participants were encouraged to respond as briefly or in depth as they wished. 
There are a number of advantages and reasons to using content analysis to review historical documents and literature, in particular it was a way to track the change and development of Pacific regionalism, and also as way to enhance the credibility of my findings. However it would naïve to believe that this method did not have flaws. As Glen A. Bowen (2009) highlights, the key disadvantages to this method are the availability of documents and the 'biased selectivity' of the documents. The former, the majority of vital documents are available on the internet for the public. Lack of availability however is something that is discussed in the finding chapters, with clear links between legitimacy and transparency of the institutions. In comparison to the Pacific Islands Forum Secretariat, the Secretariat of the Pacific Community did not have an extensive historical library available online. This did effect the balance among the documents. However, as most of the selected documents are from the Forum Leaders meetings, many of the same participants would have attended the Secretariat of the Pacific Community Conference of the Pacific Community and Committee of Representatives of Governments and Administrations (CRGA) conferences and other major regional meetings. In regard to the latter, there was a clear method to my selectivity: I chose documents from the key moments in history identified in the literature, as they represented times of strong legitimacy and often explained current/past challenges. These are: World War II (establishment of the South Pacific Community), French nuclear testing in the Pacific and decolonisation (establishment of the South Pacific Bureau), the Cold War, the Pacific Plan and the Framework for Pacific Regionalism.

All research was granted permission by the Victoria University of Wellington Human Ethics Committee. Each participant was emailed a Participant Consent form and a Participant Information form prior to the interviews (see Appendix 2). Participants were also given the option to remain anonymous, asked if they would like a summary of the findings and if telephone interviews could be recorded. All stages of this research acted in accordance with the guidelines of the Human Ethics Committee.

Figure 4: Conceptual Framework 


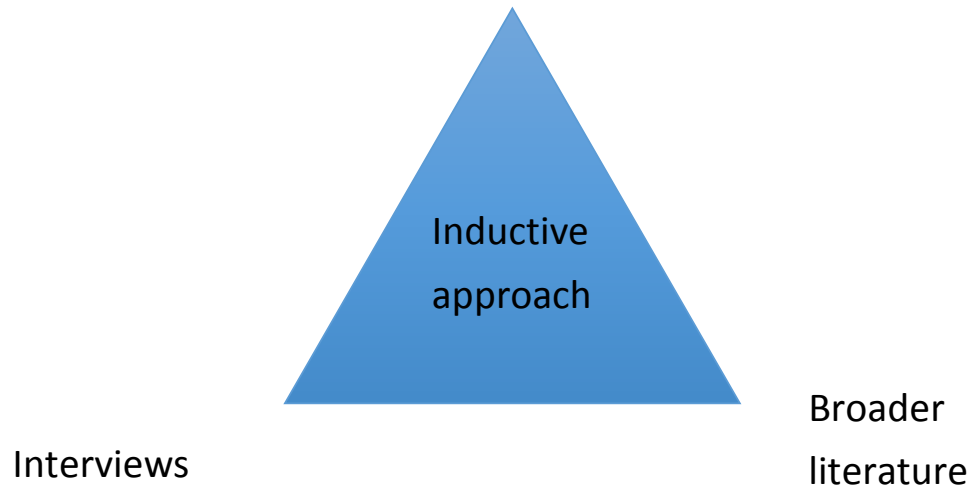

Figure 5: Document Analysis Sample:

\begin{tabular}{|c|c|c|}
\hline Document Selected & Institution/author & Data Analysed \\
\hline $\begin{array}{l}\text { Canberra Agreement } \\
\text { (South Pacific } \\
\text { Commission, 1947) }\end{array}$ & $\begin{array}{l}\text { Participating governments: } \\
\text { Australia, France, the } \\
\text { Netherlands, New Zealand, } \\
\text { the United Kingdom and } \\
\text { the United States of } \\
\text { America. }\end{array}$ & $\begin{array}{l}\text { Document establishing the } \\
\text { agreement of the South } \\
\text { Pacific Commission. } \\
\text { Establishes original } \\
\text { intentions of the } \\
\text { Commission. }\end{array}$ \\
\hline $\begin{array}{l}\text { South Pacific Forum } \\
\text { Communiqué } 1971 \text { (South } \\
\text { Pacific Forum, 1971) }\end{array}$ & $\begin{array}{l}\text { Leaders: Nauru, Samoa, } \\
\text { Tonga, Fiji, Cook Islands, } \\
\text { Australia and New Zealand }\end{array}$ & $\begin{array}{l}\text { Document exploring } \\
\text { establishment of the } \\
\text { South Pacific Forum. } \\
\text { Brings to attention key } \\
\text { challenges in regionalism } \\
\text { at the time and is the first } \\
\text { Communiqué of the } \\
\text { Forum. }\end{array}$ \\
\hline $\begin{array}{l}\text { Auckland Declaration } \\
\text { (Pacific Islands Forum, } \\
\text { 2004) }\end{array}$ & $\begin{array}{l}\text { Pacific Islands Forum } \\
(2004)\end{array}$ & $\begin{array}{l}\text { Document requesting and } \\
\text { outlining challenges/the } \\
\text { call for a review of Pacific } \\
\text { regionalism: the Eminent } \\
\text { Persons' Group and the } \\
\text { Pacific Plan. }\end{array}$ \\
\hline $\begin{array}{l}\text { Agreement Establishing } \\
\text { the Pacific Islands Forum } \\
\text { (Pacific Islands Forum, } \\
\text { 2005) }\end{array}$ & $\begin{array}{l}\text { Pacific Islands Forum } \\
(2005)\end{array}$ & $\begin{array}{l}\text { Treaty currently enforce } \\
\text { establishing the mission } \\
\text { and purpose of the Pacific } \\
\text { Islands Forum and } \\
\text { accompanying secretariat. }\end{array}$ \\
\hline The Pacific Plan: revised & Endorsed by Leaders of & Outlines improvements \\
\hline
\end{tabular}




\begin{tabular}{|c|c|c|}
\hline $\begin{array}{l}2007 \text { version (Pacific } \\
\text { Islands Forum Secretariat, } \\
2007 \text { ) }\end{array}$ & the Pacific Islands Forum & $\begin{array}{l}\text { for Pacific regionalism, } \\
\text { defines key concepts and } \\
\text { priorities and sets forth an } \\
\text { implementation plan. }\end{array}$ \\
\hline $\begin{array}{l}\text { The Pacific Plan Review } \\
2013 \text { (Pacific Plan Review, } \\
\text { 2013) }\end{array}$ & $\begin{array}{l}\text { Pacific Plan Review Team } \\
\text { on behalf of Pacific Islands } \\
\text { Forum }\end{array}$ & $\begin{array}{l}\text { A review of the progress } \\
\text { of the Pacific Plan and } \\
\text { challenges of Pacific } \\
\text { regionalism. It provided } \\
\text { processes for condensing } \\
\text { the priorities discussed at } \\
\text { Forum Leaders' Meetings. }\end{array}$ \\
\hline $\begin{array}{l}\text { The Framework for } \\
\text { Pacific Regionalism } \\
\text { (Pacific Islands Forum } \\
\text { Secretariat, 2014) }\end{array}$ & $\begin{array}{l}\text { Endorsed by Leaders of } \\
\text { the Pacific Islands Forum }\end{array}$ & $\begin{array}{l}\text { New regional policy } \\
\text { process to enhance } \\
\text { coordination. }\end{array}$ \\
\hline $\begin{array}{l}46^{\text {th }} \text { Pacific Islands Forum } \\
\text { Communiqué (Pacific } \\
\text { Islands Forum a, 2015) }\end{array}$ & $\begin{array}{l}\text { Pacific Islands Forum } \\
\text { (2015) }\end{array}$ & $\begin{array}{l}\text { Most recent Communiqué } \\
\text { from the } 2015 \text { Forum } \\
\text { Leaders' Meeting. } \\
\text { Provides a basis for } \\
\text { current issues and process } \\
\text { within Pacific Regionalism }\end{array}$ \\
\hline $\begin{array}{l}13^{\text {th }} \text { South Pacific Forum } \\
\text { Communiqué (South } \\
\text { Pacific Forum, 1982) }\end{array}$ & South Pacific Forum (1982) & $\begin{array}{l}\text { Forum Leaders' Meeting } \\
\text { with a focus on fisheries } \\
\text { and the Law of the Sea } \\
\text { Convention. }\end{array}$ \\
\hline $\begin{array}{l}\text { South Pacific Forum } \\
\text { Meeting on Law of the } \\
\text { Sea Communiqué (South } \\
\text { Pacific Forum, 1976) }\end{array}$ & $\begin{array}{l}\text { South Pacific Forum, } \\
\text { special meeting on Law of } \\
\text { the Sea (1976) }\end{array}$ & $\begin{array}{l}\text { Review of the } \\
\text { development of the Law } \\
\text { of the Sea Conference. }\end{array}$ \\
\hline $\begin{array}{l}5^{\text {th }} \text { South Pacific Forum } \\
\text { Communiqué (South } \\
\text { Pacific Forum, 1974) }\end{array}$ & South Pacific Forum (1982) & $\begin{array}{l}\text { Forum Leaders' Meeting } \\
\text { with a focus on nuclear } \\
\text { testing, as well as Law of } \\
\text { the Sea and fishing policy. }\end{array}$ \\
\hline $\begin{array}{l}\text { South Pacific Nuclear- } \\
\text { Free Zone (Treaty of } \\
\text { Rarotonga) (South Pacific } \\
\text { Bureau for Economic } \\
\text { Cooperation, 1985) }\end{array}$ & $\begin{array}{l}\text { Endorsed by Australia, } \\
\text { Cook Islands, Fiji, Kiribati, } \\
\text { Nauru, New Zealand, Niue, } \\
\text { Papua New Guinea, } \\
\text { Samoa, Solomon Islands, } \\
\text { Tonga, Tuvalu, Vanuatu }\end{array}$ & $\begin{array}{l}\text { Treaty endorsing a nuclear } \\
\text { free Pacific. An important } \\
\text { milestone in the region, } \\
\text { and considered one of the } \\
\text { biggest successes of } \\
\text { regionalism. }\end{array}$ \\
\hline $\begin{array}{l}\text { Secretariat of the Pacific } \\
\text { Community website - } \\
\text { history and about page } \\
\text { (Secretariat of the Pacific } \\
\text { Community a, 2011; } \\
\text { Secretariat of the Pacific } \\
\text { Community a, 2011) }\end{array}$ & $\begin{array}{l}\text { Secretariat of the Pacific } \\
\text { Community website }\end{array}$ & $\begin{array}{l}\text { The organisation's } \\
\text { website: public face and } \\
\text { explanation of role in } \\
\text { regional affairs }\end{array}$ \\
\hline Pacific Islands Forum & Pacific Islands Forum & The organisation's \\
\hline
\end{tabular}




\begin{tabular}{|l|l|l|}
\hline $\begin{array}{l}\text { Secretariat website - } \\
\text { About Us (Pacific Islands } \\
\text { Forum Secretariat a, n.d.) }\end{array}$ & Secretariat website & $\begin{array}{l}\text { website: public face and } \\
\text { explanation of role in } \\
\text { regional affairs }\end{array}$ \\
\hline $\begin{array}{l}\text { Dame Meg Taylor Speech } \\
\text { at VUW (Taylor, 2015) }\end{array}$ & $\begin{array}{l}\text { Dame Meg Taylor, Pacific } \\
\text { Islands Forum Secretariat } \\
(2015)\end{array}$ & $\begin{array}{l}\text { Future of Pacific } \\
\text { regionalism and the } \\
\text { Framework }\end{array}$ \\
\hline
\end{tabular}




\section{FINDINGS AND DISCUSSION:}

\section{EXPLORATION AND CONVERSATION}


Critical junctures are defined in the Literature Review as a major event or moment that has sparked change within a society. Critical junctures are moments in history that can prompt momentum and provide an opportunity for political, social or economic bargaining. The authors Acemoglu and Robinson (2012, p. 101) believe that if institutions or organisations operate in the interests of the public, critical junctures provide important moments for people to campaign for their rights and create change. They argue that this process enhances legitimacy, as people are more likely to feel ownership over the organisations. Based on historical documents, there are clearly points in Pacific history that have sparked members to become more interested or involved in regional organisations ${ }^{8}$. Some of the key examples are French nuclear testing, decolonisation, the UNCLOS, the Cold War and the Pacific Plan. This is evident from new members joining, stronger language in documentation and more coverage of particular issues. A specific example is the 1974 South Pacific Forum Communiqué which used stern language toward the French who were, at that time, continuing with nuclear testing. The leaders 'deplored the fact that despite the declaration, France has since carried out further tests' and was 'concerned about the health of people and the environment' (South Pacific Forum, 1974). This Communiqué expressed the feelings around the Pacific region at that time, and took charge collectively to find a solution. Arguably, these were moments where the regional organisations were much more on the agendas of Pacific people's minds, there was a clear purpose for why it was necessary to address the issues regionally and the successes prompted people to be proud to be a Pacific Islander. This chapter will aim to discover if it is critical junctures that legitimise regional organisations, and if so, how can the organisations be positioned to ensure that they make the most of these opportunities when they arise.

\section{Personal stories:}

In order to explore whether critical junctures played an important role in the Pacific, and to divulge further into the ideas of my document analysis, I asked interview participants at what point in their careers did they decide or consider regionalisation

\footnotetext{
${ }^{8}$ Sources: (South Pacific Commission, 1947; South Pacific Forum, 1971; Pacific Islands Forum, 2005; Pacific Islands Forum Secretariat, 2007; Pacific Plan Review, 2013; Pacific Islands Forum Secretariat, 2014; Pacific Islands Forum a, 2015; South Pacific Forum, 1982; South Pacific Forum, 1974; South Pacific Bureau for Economic Cooperation, 1985)
} 
to be an effective approach to the Pacific. The idea of this question was to get a personal account of when many of the interview participants thought of regionalism to be a legitimate approach to work towards and support. Many of the participants have devoted years, or the larger extent of their careers, to this form of development. As it is people who shape policy and change, their opinions on when regionalism appeared to be an effective approach provides an interesting insight into motives and legitimacy. Participants' responses varied hugely, but there was a common theme that aligned with my document analysis. Critical junctures throughout history have played an important role in legitimising regional organisations. Examples mentioned were: French nuclear testing, Ratu Mara and Michael Somare's influence on the region, decolonisation, the negotiations of UNCLOS and drift-net fishing (Anonymous; Dame Meg Taylor; Alan Morris). This finding was not particularly surprising based on the frequency and prioritisation of these moments in my analysis of historical documents. It is evident that for many people, regionalism becomes more exciting when there is a clear opportunity for great change. It is worth noting that these moments affected most or all of the Pacific Island nations involved, which is most likely why they have been established as regional critical junctures, not national historical moments. Some participants mentioned that there is a need to define regionalism, in order to decide if it is effective, as some approaches have proven more successful than others (Dr Tess Newton Cain, Alan Morris, Peter Bazeley, Greg Fry). For example, Greg Fry stated that regional integration is not an effective approach for the Pacific, but 'regionalism can be highly effective if defined as joint diplomacy'.

Another common finding was that participants' early introduction to regionalism was not something they viewed as very important. In the case of Peter Bazeley, who was based in Vanuatu, and Dame Meg Taylor, once based in Papua New Guinea, during the early days of decolonisation and self-government both were much more concerned with domestic affairs than the wider Pacific. As Dame Meg Taylor stated: 'There were so many exciting things going on in our own country - which was huge - we were all so absorbed in that, that we almost seemed to be self-sufficient in our own dialogue with our development partners ${ }^{\prime 9}$. Both participants noted that times have changed and due

\footnotetext{
${ }^{9}$ All interview quotes will be presented in italics
} 
to geopolitics the Pacific is now more connected. Peter Bazeley noted that there was always a need or potential for 'trade, common norms and standards, [and] movement of people'. Dame Meg Taylor noted the more prominent role of Papua New Guinea in regionalism and there is 'a greater sense of importance for the country itself as it looks beyond from ... [itself] ... in terms of the region. That it [PNG] can play a role in the region'. Furthermore, that the politics of the region have proven that these relationships are important and regionalism can make an impact.

However, most participants also expressed some doubt in the effectiveness of regionalism (Dr Tess Newton Cain, Dr Matthew Dornan, Alan Morris, Peter Bazeley, Dame Meg Taylor). As Dr Tess Newton Cain stated:

I have to be realistic, and there have been some serious challenges that haven't necessarily been overcome, there have been some successes, and that's really what I try and spend my time trying to work out. How can we mitigate the risks and promote the opportunities for it to work better in the future if it is the way that Pacific Island countries want to come?

There was support for the future of regionalism in the Pacific, however many participants were wary that to many regionalism is the 'default approach' (Dr Matthew Dornan; Dr Tess Newton Cain) for donors and members, or that: 'the Forum Secretariat has drifted a bit over the years, and a lot of its activity has become what I think they call themselves 'legacy issues' ... [where] you can trawl back through all the old declarations and find them' (Alan Morris).

In the case of people taking time to prioritise regionalism, I think that this is positive. It would not be realistic to expect that someone would immediately grasp the importance of these governing agencies with all of their complexities. It also means that these people have taken time to consider and analyse how and why regionalism could potentially be effective. Furthermore, it means that they understand the difficulty of converting from a national-perspective to one that also includes regionalism. These thoughts express that they understand the power of critical junctures, and the ability these moments have to prompt bargaining and create change. It also signifies that need for on-going change and shifting, that organisations 
cannot 'rest on their laurels' or successes in order to remain relevant players. Overall, it is evident that participants took a long-term view of regionalism, and their personal 'revelation' of regionalism, as an effective approach, was more of a gradual realisation, rather than a sudden change spurred from one successful critical juncture.

Optimism and potential were commonly expressed, especially with the momentum of the Framework for Pacific Regionalism. However, there was consensus that the Framework needs to grow in order to be truly game changing (Dr Tess Newton Cain; Dame Meg Taylor, Peter Bazeley; Anonymous; Alan Morris). This was a common finding and one that validated the theory of critical junctures: Participants stated that there are times in history where the different member states have interest in regional organisations, and it was not until an event or issues occurred that united the region, that all members were involved and interested (Dame Meg Taylor; Alan Morris; Peter Bazeley).

Be nimble:

The theory of critical junctures was more or less supported by all participants. However, as many stated, it is much more complex and does not necessarily provide a solution to maintaining on-going legitimacy in regional organisations. As Alan Morris said: 'If you could manufacture a string of critical junctures at regular intervals then you wouldn't have a problem ... It's in the laps of the gods'. In a similar vein, the Pacific Plan Review 2013 stated that there are 'comparatively few - long-standing examples of Pacific regionalism have diverse origins. They cannot be said to be the result of regular, purposeful, institutionalised, contemporary political processes and dialogues about the future of the region' (Pacific Plan Review, 2013). If the theory is that critical junctures are moments in history that have sparked change and enhanced legitimacy of these organisations, then how can regional organisations be supported to position themselves to recognise and act at any critical juncture? The most common answer to this question was serious and frank dialogue between members. Most participants attributed this to being a vital role of the Framework process (Dr Tess Netwon Cain, Dr Matthew Dornan, Peter Bazeley, Dame Meg Taylor, Alan Morris, Soli Middleby). Dr Tess Newton Cain emphasised that: 'the Framework does allow the Pacific Islands Forum to have access to a wider range of inputs that may help in terms of identifying 
critical junctures'. Alan Morris also reflected that many of the organisations are tied down by 'legacy issues' or agenda items that have been a part of the Forum Leaders Meetings for a long time, he stated 'you can trawl back through all the old declarations and find them. I think a lot of people don't understand why or have asked why they are still important'. The hope from participants was that the Framework would create the necessary change. As mentioned earlier, the findings suggest that further discussion will be essential to reshape Pacific regionalism and its key focuses. Furthermore, Peter Bazeley stated:

'if there were a serious political dialogue about what we want the region to look like and what are the big game changing issues that we need to address, with real political leadership that PNG are providing at the moment, then I think there is an opportunity...that PIFS and then the others following will suddenly realise that there is a really important role for them which they failed to deserve up until now'

In a similar line of thought, Soli Middleby indicated that identifying critical junctures comes down to the organisations:

'being well governed and managed - both in terms of broad governance that furthers legitimacy at the national level, and just basic management within the organisations so that should an opportunity arise, the organisation can adapt to get behind something new. By being proactive with policy thinking and advice scanning the context and environment for such junctures'

The Framework for Pacific Regionalism is one of the most common themes for optimism and critique throughout the findings. In the case of the Framework, much of discussion that arises is about how it will grow and develop over time. This means that it is vital that regional organisations, especially the Pacific Islands Forum Secretariat take a lead to ensure that the Framework remains a matter of interest for Pacific people. Based on research of critical junctures through the documents, it is evident that the Framework could represent one of the next critical junctures for the Pacific. It fits in with much of the basic criteria, in that it is: a significant shift; encourages the public to engage; and Pacific ownership is at the forefront. Through the Specialist Sub- 
Committee, the Framework gives the Pacific the opportunity to work on issues that interest the Pacific; old issues can be put aside and the organisations can focus on acting 'more nimbly' (Dr Tess Newton Cain) and reactively to the changing environment. However, if the Framework is to drive change, officials must be held to account in the implementation of Leaders' decisions. This role must and has fallen to the Forum Secretariat. If open and frank dialogue can continue, and Pacific leaders and officials make the most of the flexible nature of the Framework, there is huge potential for an exciting shift in the legitimacy and management of regional organisations.

Other participants mentioned very similar management ideas, and in particular the importance of strong leadership and attracting staff who have adaptive skills (Soli Middleby, Alan Morris, Peter Bazeley, Anonymous). Pacific regional organisations often struggle to recruit and retain qualified staff members. Effective management has proven difficult in the Pacific. The region already suffers from capacity constraints, and as evidenced by participants this is also an issue within regional organisations. (Soli Middleby, Peter Bazeley, Alan Morris). From my experience many of the best staff move to the United Nations agencies, or a similar organisation based in Suva, when their passion for regionalism peters out. The question of how to interest the Pacific's best new leaders into these roles is also difficult when regional organisations cannot offer the same benefits, salaries or prestige as international institutions. From the participants' personal stories it could be deduced that critical junctures also could play a vital role in recruiting strong leadership and talented policy makers (Anonymous, Dame Meg Taylor, Alan Morris, Peter Bazeley, Soli Middleby).

Another common theme mentioned in regard to this question were new critical junctures and how they have been identified. This correlated with comments about strong leadership, as some participants outlined the 2014 appointment of the new Secretary General at the Pacific Islands Forum Secretariat, Dame Meg Taylor as a critical juncture. As Alan Morris stated 'personalities among the organisations help cooperation', and this is evident based on findings that suggest the work of former Pacific leaders and champions of regionalism prompted interest. Ratu Mara and Michael Somare. Peter Bazeley went on further to say, 'I think Dame Meg has done a 
seriously good job at upping the game at PIFS. She is having much more serious, substantive and relevant political discussions with the Pacific leaders'. It is also evident through the media that Dame Meg Taylor's position as Secretary General has sparked some momentum and excitement in the regional sphere (Placek, 2014).

Participants put emphasis on the recent work at the 2015 Paris Climate Change Conference COP21. The challenge of climate change has been a major focus on regional agendas for over a decade, and as Soli Middleby stated, 'climate change, as an adverse threat, is delivering a more reactive, but no less relevant version of regionalism and will continue to do so - other external forces, particular environmental ones that threaten livelihoods, also have potential to lead to greater regionalism'. Dame Meg Taylor who had recently come back from the Paris Conference indicated that COP21 was:

'one issue where I thought, the only way we are going to get a good result is if we stick together... and every statement that a Pacific leader made, there was a thread on what the priorities were in terms of climate and climate finance. That showed that there are issues that, yes you've got your own island issues or your own state issues, but for the good of the region, we are all impacted by this, nobody is not going to be impacted.'

The anonymous participant furthered this comment of climate change as a critical juncture, and explained that, 'despite differing positions in some areas, the region's cooperation in the build up to COP21 and during the negotiations at COP21 is a very recent example of what regional coordination and advocacy can achieve'.

The question here lies, how can these issues be made into critical junctures that will unite and create positive change in the Pacific? Conversely $\mathrm{Dr}$ Tess Newton Cain pointed out: 'One of my concerns with critical junctures is...they are much easier to identify in hindsight...than to prepare organisational structures to be ready'. Often it is only after an issue has found a solution or an agreement has been made by all members, that the issue is considered to have united the region. 
In this way, Dr Tess Newton Cain puts forward a valid point about identifying critical junctures. However, perhaps if the institutional framework was adapted to be more receptive to the concept of the critical juncture, then it may be easier to identify them earlier on. Climate change has certainly created a big impact in the region, and as participants stated, it has helped in replicating similar momentum to historical critical junctures. Alan Morris explained:

'[most of the time] really not a lot happens, unless there is an issue that unites them all in a way that draws on the concerns they have for their own national circumstances as well as regional, for example nuclear testing. On today's agenda it might be something like freedom of movement around the Pacific, for example, visas, labour mobility. Labour mobility... [is]... not yet registered as a critical juncture'

Further to this, Alan Morris stated that many issues need to be recognised as critical junctures. He suggested that issues, such as labour mobility or development statistics, where 'you would hardly call that a critical juncture, but it is a critical issue'. He further established:

'There are non-sexy things that really are important for the growth of the region as a whole. That if somehow they could be made sexy enough so that people are actually paying attention to them in a way that they give attention [to other critical junctures]. It's very hard to get political leaders interested in things like statistics'

Creating interest on issues or initiatives that do not have the same kind of public interest, but are still essential for development, is much more difficult to attain. Many of these issues are quite niche or technical; they require much more focus and are not always something that a member government wants to highly prioritise. This is why regional organisations need to include specialist advisors who can articulate the importance of critical issues in order for people to appreciate their existence. Regional organisations cannot always be supporting glamorous or highly pressing issues, sometimes their use can be found in more practical, less exciting fields. I think in this 
case, it is something that the organisations and leaders need to take a stand on, and with their support, change can hopefully be accomplished.

\section{Conclusion}

This chapter has analysed the theory that critical junctures promote legitimacy in international or regional organisations. Firstly it looked people's introductions to Pacific regional organisations as an effective form of delivering positive development outcomes. People's responses varied, but there some did align with the findings of the document analysis, i.e. that significant moments in history helped legitimise Pacific regionalism. However, there was some pragmatism and scepticism that critical junctures have the power to be game-changing, particularly when these events cannot be manufactured at regular intervals throughout history. There is also the fact that many essential developments for the region, like statistics or migration, have trouble gaining leader support as they are often not considered to be exciting. From the findings, it is evident that critical junctures are opportunities for wider engagement of regionalism. However, they do not seem to affect the commitment of key players, who underline the issue of how to keep regionalism alive on a continual basis. This chapter analysed all these issues and discussed them through the 'Complex Standard' (Buchanan \& Keohane, 2006). Critical junctures demonstrated that they heighten institutional integrity and provide comparative benefit. They are moments where the organisations appear to be more valuable, needed and worthy of support. If organisations can position themselves to be more nimble and work more proactively to identify opportunities, they may not be able to fabricate critical junctures, but they can make the most of the ones that organically appear. 


\section{COLLECTIVE ACTION}

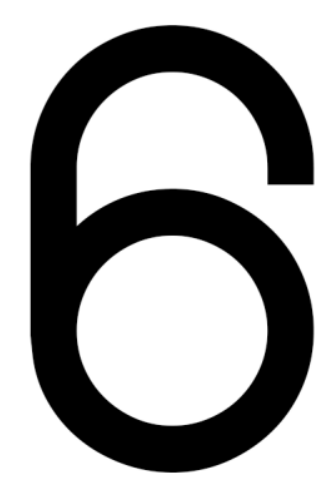

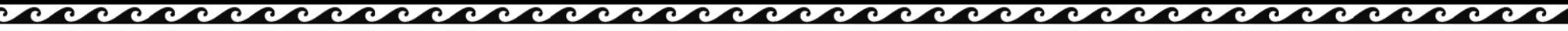

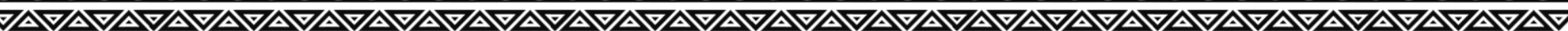

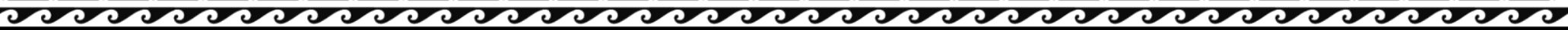

This research defines collective action as people of the Pacific coordinating together to enhance the response to regional issues and achieve a common objective to provide benefit to the region's wellbeing. Collective action is one of the key goals of regionalism because if people do not feel as though they are part of a community, it is very difficult to encourage effective and cohesive development. Dame Meg Taylor talked of an ideal regionalism in an address at the Victoria University of Wellington in 2015: 'A regionalism that would acknowledge and recognise our shared challenges, draw on our many shared strengthens, build the political will to act collectively, and devise and carry out effective, collective solutions and challenges - whether through technical or political means' (Taylor, 2015). A quick scan of organisational documents finds that some of most common phrases in Pacific regional literature are words like: coordination; together; Pacific people; collectively; cooperation; united and community $^{10}$. Collective action is key to the success of these organisations, and arguably one of the key steps toward legitimacy. In the 'Standard' criteria, some of the key elements legitimacy are based on: democratic consent; comparative benefit; and institutional integrity; all of which are difficult to achieve without a sense of unity. In the Framework for Pacific Regionalism, it was stated that leaders 'strive for effective, open and honest relationships and inclusive and enduring partnerships - based on mutual accountability and respect - with each other, within our sub-regions, within our region and beyond' (Pacific Islands Forum Secretariat, 2014, p. 3). This chapter asks how Pacific regionalism can make a productive effort to encourage collective action.

\footnotetext{
${ }^{10}$ Sources: (South Pacific Commission, 1947; South Pacific Forum, 1971; Pacific Islands Forum, 2005; Pacific Islands Forum Secretariat, 2007; Pacific Plan Review, 2013; Pacific Islands Forum Secretariat, 2014; Pacific Islands Forum a, 2015; South Pacific Forum, 1982; South Pacific Forum, 1974; South Pacific Bureau for Economic Cooperation, 1985; Pacific Islands Forum, 2004; Pacific Islands Forum Secretariat a, n.d.; Secretariat of the Pacific Community a, 2011; Taylor, 2015)
} 
The chapter looks at some of the major threats to collective action, like the dominance of donors and regional geopolitics. It also discusses the complex balancing act between protecting state sovereignty and nationalism, while fostering collective action and the legitimacy of regionalism.

When answering questions about collective action, and how a productive effort can be made in order to enhance legitimacy, most participants looked at the future of regionalism in the Pacific. In addition to this, I asked participants to discuss what they believed to be the future of Pacific regionalism, and how on-going legitimacy could be maintained. The responses to these questions varied widely, and on reflection are probably a good indication of the many differing opinions of the future direction of Pacific regional organisations. When considering collective action, many participants looked at the current political climate in the Pacific, in particular the changes in diplomatic relations and power shifts (Dr Tess Newton Cain, Dr Matthew Dornan, Dame Meg Taylor, Soli Middleby). Papua New Guinea is playing a much larger role in the region than ever before and their economic power is creating change. As $\mathrm{Dr}$ Tess Newton Cain stated the tensions between the Pacific and the rest of the world will never rival the tensions between Pacific Island countries because it is just too complex and too historical'. Soli Middleby suggested that the complexities of the region need to be understood more clearly:

'the political economy of the Pacific at present does not encourage genuine commitment to the types of political settlements that could truly be 'game changing' for this region; aid is a significant part of the problem i.e. countries do not have the incentives to work together to address their challenges and remain highly dependent of aid - with a view they always will'

Current geopolitics are shaping the region's dynamic and the way issues are approached. With a Papua New Guinean Secretary General at PIFS and the 2015 Leaders Meeting in Port Moresby, PNG is taking a much more active role in the regional affairs. The country is also hosting the 2018 Asia-Pacific Economic Cooperation (APEC) conference demonstrating a real desire to be a part of regional dialogue and flex its muscles as a strong sovereign state (Callick, 2013). PNG's power and new found support for the region is arguably encouraging Pacific people to take a 
second look at the organisations. There is also Fiji who has been invited back into the Forum, but is hesitant to commit to a platform that they believe is heavily dominated by the metropolitan powers (Bola-Bari, 2015). Dame Meg Taylor mentioned in her interview that in the early days of formalised regionalism, it was the Polynesians who held control of the affairs. It could be said that now the tables are turning and more balance can be found on Pacific regional platforms.

However these sentiments did not lead participants to think that there will not be a future of Pacific regionalism. As cited in the literature review, many believe that collective diplomacy is one of the greatest successes of Pacific regional history, as well as providing hope for the future. As Soli Middleby said, 'the Pacific can play a very powerful role, in particular over the stewardship of the Pacific Ocean, or the fact they are 6\% if the UN General Assembly if countries can work collectively'. The power of the collective Pacific has in the international arena was a common response from participants, and many believed that it will remain an important part of Pacific foreign policy. Dr Matthew Dornan expressed similar sentiments, but also believed that there will never be a 'clean Pacific regionalism' where there is one organisation that coordinates all issues: 'I think that is too much to hope for. Instead we will have the current situation which is lots of different Pacific regional organisations, some coordination between them, some disagreement, some of them being supported by different powers for geopolitical reasons'.

Whether one organisation would be the best result for the region is worth disputing. In particular, the roles of the Pacific Community and the Forum are very different, although not always in practice. Once again, this highlights the need for the organisations to produce clearer mandates and maintain cooperative relationships built on trust. This could help ensure that the two major organisations worked seamlessly together, in the region and on international platforms. However, some disagreement will always be necessary in order to create positive and robust dialogue. If one organisation is what critics desire then possibly two harmonised organisations is the more realistic dream.

The Framework for Pacific Regionalism has a key focus on the future of Pacific regionalism and the complexities of collective action (Pacific Islands Forum Secretariat, 
2014). Throughout the interviews, the work of the Framework gave many a sense of optimism for the future. As Soli Middleby stated: 'the Framework for Pacific Regionalism probably is going to encourage greater collective action if it is implemented as intended'. No one was quick to say that the Framework was a complete success, many expressed excitement but also the need for patience and time to ensure the process could settle into the region's architecture. This sentiment was discussed by Dame Meg Taylor, who discussed the complexity of the process:

'Now that gives the voice to people in the Pacific, then you have ministerial [level] and they have their priorities for the region, and then it is for the leaders to act on what are the priorities for this region, so that we have a development paradigm that shifts to ensure that the leaders of the Pacific are the ones deciding what happens'

The Framework is demonstrating that it can influence people to think more about the region collectively. Even if it is early days in the process, it is the first time that Pacific people, from all levels, have been able to have a direct role in regional decision-making and the highlighting of issues.

There was also a fair amount of scepticism about the Framework. Peter Bazeley, Greg Fry and Alan Morris all stated that the Framework has been misunderstood or reinterpreted by the Pacific Islands Forum Secretariat. Peter Bazeley stated that his vision was for the Framework to be 'the whole purpose of PIFS, beyond the subcommittee. Providing a much higher base for evidence, game changing, political dialogue that would really shape the economic efficiency of the region'. Alan Morris suggested that at the Forum Secretariat: 'there is a strong school of thought that it [the Framework] is a clip-on to what they have always been doing, rather than fundamental to what they $d o^{\prime}$. Perhaps suggesting that the Specialist Sub-Committee for Pacific Regionalism is a tokenistic reform, in order to ensure change does not happen. Alan Morris believes the last Forum meeting in Port Moresby was 'a little bit disappointing' and the Communiqué and accompanying documents 'basically picked up most of the issues that the sub-committee and the Forum Secretariat settled on, but they sort of just tacked them on to the end of the same old same old Communiqué. You know what it's like, you could almost write it in your sleep'. 
Perhaps the argument of the misunderstanding of the Framework is part of a slower rolling out of the process. This was the first year of the Framework, and in many ways, a test-run for the region. The organisations will likely be open to criticism and the flexibility of the Framework means that it can be reinterpreted to fit in with the current regional architecture. There was a strong sense that the Communiqué for the $46^{\text {th }}$ Pacific Islands Forum was very similar to past communiqués, however unlike many of the past, Pacific people did have a chance to voice their concerns.

The year 2015 was the first year of the Specialist Sub-Committee and the first time the Framework had come into play. Participants expressed that with improved understanding of the processes (within the organisations and the rest of the region) there is hope for improvement. Understanding the reality of the Framework and the intentions of the Review Team, regional bureaucrats and Pacific Leaders will take time to embrace and implement required change. As stated earlier, many participants consider the Framework to be a critical juncture: an important moment that has the potential to create great change. Soli Middleby suggested that if implemented as planned by the Review Team, the Framework will mean:

'Focusing on fewer, bigger issues, and ensuring genuine political commitment is essential. Genuine developmental leadership and commitment across the region, both within countries and regional institutions, reformed financing arrangements and the according shift in the 'development paradigm' away from donor control to country control are all essential should a more 'proactive' version of Pacific regionalism deliver more collective action'

In the Literature Review one of the sub-themes discussed is the varieties in different types of regionalism. This is an on-going debate in the Pacific and one of the main findings of the influential Asian Development Bank document Toward a New Pacific Regionalism (Asian Development Bank-Commonwealth Secretariat, 2005). The document discussed three different types of regionalism: cooperation, pooled service delivery and integration. This document was discussed by a number of participants in regard to encouraging collective action. Dr Matthew Dornan discussed the scope for economic integration in the Pacific, but believed that the biggest gains would most likely happen with metropolitan powers, rather than just between Pacific countries. 
Peter Bazeley had some doubts that economic integration would ever be a viable option for the Pacific. He stated: 'I don't think politically there is a particular appetite for much but there are some kind of headline things, but I don't think from a political, social or culture perspective there is much to get to be holding your breath in excitement about it in terms of regionalism'. Dr Tess Newton Cain pointed out that one of the reasons why pooled service delivery or closer integration fails is because 'by the time they get around to doing it regionally some of the countries are already doing it anyway and there is no real incentive for them to join the regional thing'. She cited this as a common problem within the region, where some countries have more advanced technology or more capacity than others. Some examples were Information Communications Technology (ICT) or national universities competing with the University of the South Pacific (USP). Dr Tess Newton Cain questioned why member states would want to join a regional initiative if there was no need for them to join. Regional organisations need to provide benefits for all member states, or at least provide incentives to keep everyone involved in the dialogue.

In the case of USP, this issue, arguably, could be presented as an opportunity to choose to work with or against national universities. In many cases already, it works with national universities to supplement lesser resourced campuses. More universities in the Pacific would not necessarily be a negative settlement. USP could position itself to focus more on research and post-graduate education while it supports national universities in the process. For the future of Pacific development, regional initiatives need to avoid 'knee-jerk' criticism in relation to sub-regional or national level actions and not see them as a threat, but instead as a chance to build capacity. This is a naturally occurring process in an evolving and maturing region. It is essential that the capacity of all Pacific regional organisations to similarly evolve and mature that will, most likely, define their success or failure.

She suggested the possibility of growing the Recognised Seasonal Employer (RSE) scheme which would increase labour mobility within the region. Leaving Papua New Guinea out of the picture, who already have the job capacity, Dr Tess Newton Cain expressed that labour mobility would provide 'something for everybody', and would not be 'seen to be promoting one country over another...because they all have tourism, 
they all have coffee, they all have labour, there is very little differentiation once you take resources out of it' and could provide some much needed capacity, as well as upskilling for Pacific people. Dr Matthew Dornan agreed with Dr Tess Newton Cain's sentiments, stating that 'Pacific trade and investment has been quite successful because it has balanced national priorities against regional priorities, and I think you could expand its mandate to include labour'.

Further integration is a common theme in the literature and could mean many different initiatives for the region. Due to economies of scale, the benefits are not always there for each member state. It is very difficult to get small economies to sign up to initiatives that do not have obvious or large incentives. The size of the Papua New Guinean or Fijian economy, in comparison to some of the Micronesian states is very different, and they also have varying levels of development and unique challenges. Finding critical junctures or initiatives that are new or vital to the entire region is not something that can be fabricated on a regular basis. There will always be countries that are behind or ahead of others. As Dr Matthew Dornan stated, this is why the metropolitan powers have an important role in the Pacific region. Their place on the table may be contentious, but the opportunities they can provide for trade, investment and up skilling offer a very good argument for their seat. Regional organisation need to accept their role in an evolving region, and be open to the idea of umbrella initiatives in circumstances where sub-regionalism makes the most sense, and countries have different demands and aspirations.

\section{Donors undermine?}

One of the most controversial elements of Pacific regional organisations is the role of development partners as members of the organisations. The role of metropolitan states within regional organisations is a unique complexity of the Pacific region, and without careful management can cause power imbalances on the agenda. Participants were asked if the role of donors undermines the legitimacy of regional organisations. Most participants firstly spoke about the incentives for donors to use regional organisations as a mode of development. As Dr Tess Newton Cain expressed: delivering funds through regional organisations is 'cost-effective from their point of view in theory because it minimises their transaction costs and their management costs' 
(similarly expressed by $\operatorname{Dr}$ Matthew Dornan). Soli Middleby, who worked for the Australian Aid Program for many years criticised earlier approaches to regional aid delivery, stating: 'often they took a cookie-cutter approach and therefore were not context specific and lacked ownership and buy in necessary for sustainability'. Although significant steps have been put forward to ensure that regional programmes are about Pacific cooperation, there is still a lot of criticism about the dominant role donors play in these regional organisations.

As Peter Bazeley reflected:

'what a shame it is that whenever the Pacific says we want to do something to change it is automatically assumed that that change will be brought about by an aid project. Not through political dialogue, by changing the rules of the game, if you like, about how the Pacific governs itself and its region and relates to external parties'

He further argued that this changes how Pacific people and outsiders understand development in the region. Where many people view influence coming from the 'financial benevolence or the interests' of donors, and this also shapes the ownership of the regional organisations. Alan Morris, who has attended numerous SPC and PIF conferences remarked that 'The minute Australia speaks...my sense is the rest of the room hears them as a dominant financer of the organisation' as opposed to another member with equal power at the table. He further expressed about how Australia 'has flexed its financial muscle' within the region as the largest contributor to the organisation, and one that has 'carried the day in the Communiqué decisions against the wishes and aspirations of the overwhelming majority of members'. The donors also have the capacity to invest a lot of time and resource into the large regional meetings, unlike Pacific leaders and officials who probably 'read the [four inch] briefing notes on the plane on the way over' (Alan Morris).

Further to this, Alan Morris believes that the Abbott government added additional complexities into an already confusing role. New Zealand was also mentioned by participants as the other metropolitan state within the PIF. However, most seemed to suggest that Australia played a much more influential role of dominance and suggested 
that New Zealand saw itself more as part of the Pacific region (Alan Morris, Peter Bazeley). Soli Middleby argued that donors undermine legitimate regionalism and collective cooperation:

'through the role they play at the national level, as it creates less incentive for countries to have to work together, but also at the regional level as they can support regional public goods that may not be optimal as those paying for them are not those benefiting from them'

The influence that the two major donor members have over the region does arguably affect the ownership of the organisations. Fijian Prime Minister, Frank Bainimarama, has quite publicly highlighted this issue, and set up his own Pacific-led regional organisation very similar to the PIF that does not include metropolitan powers (Radio New Zealand, 2015). Greg Fry argued that Pacific leadership and collective diplomacy is much more effective without Australia and New Zealand's involvement. He cited COP21 as an example of Island leaders were able to collectively recognise their influence in global affairs without donor interference. The Pacific Plan Review 2013 explained the complexity of the donor-member relationship, where:

'On one hand, accusations abound that donors ultimately control, through the 'power of the purse', the programme of an otherwise sovereign membership organisation and, on the other hand, that anything less than a hands-on approach by donor agencies will not suffice in terms of meeting legitimate accountability requirements to their tax payers' (Pacific Plan Review, 2013, p. 20)

As evident from the literature review, the inclusion of Australia and New Zealand in the Forum has been contested ever since the first gathering with Ratu Mara. Throughout history though, there are arguably many successes the region has gained due to the support of the two member donors, for example French Nuclear Testing or the UNCLOS (South Pacific Bureau for Economic Cooperation, 1985; South Pacific Forum, 1971; South Pacific Forum, 1974). It is also worth noting that it is probably quite easy to blame Australia and New Zealand for many of the outcomes of these 
meetings. As only a select few are present during the meetings, it is difficult to pin point what actually occurred and which member states supported different outcomes.

Beyond the dominance of Australia, or New Zealand, the European Union (EU) is currently the Pacific Community's largest project funder and also has projects within PIFS. As stated in the Pacific Plan Review 2013, 'donor financing of international membership organisations invariably brings with it tensions and frustrations' (Pacific Plan Review, 2013, p. 21). Alan Morris argued that the EU 'funds what it wants done and it won't fund what it doesn't want done, so there you have the agenda totally skewed'. France and the United States are also member states of SPC, Alan Morris argues that although their contributions are quite 'insignificant', in comparison to some of the other larger donors, they too 'try to exercise a lot more influence than their contribution would warrant'. Peter Bazeley argued that this style of regional affairs 'disempowers the real [Pacific] governing bodies who...feel that there is no real point, we have no particular function here...besides going to cocktail parties, but also that these organisations are about implementing donor projects'.

Participants stated that this undermined the legitimacy of these organisations because due to the financial architecture of these organisations, they heavily depend on project funding (Alan Morris, Dame Meg Taylor, Peter Bazeley). Dame Meg Taylor strongly articulated that people lose interest if there is no financial capital within an organisation, and that it is an important aspect of legitimacy in an organisation. According to Alan Morris and Peter Bazeley, this is something that goes beyond the articulated priorities of the leaders of member countries, it is about the relationships with the middle managers of the donor community and the regional organisations who discuss 'about the allocation of donor funds and continuation of donor projects' (Peter Bazeley).

One of the major issues with the funding and power of these outside organisations is that they do not have an obligation to align with the vision, mantra or agenda of the organisations. Unlike Australia and New Zealand, who are members and must prescribe initiatives that work within the boundaries of what the organisations want, the EU has enough funds to be able to influence the organisations from their own perspective. Further from this the EU also has very comprehensive monitoring and 
evaluation frameworks, as well as a deeply bureaucratic system based on the other side of the world in Brussels. As participants have noted, the organisations need these projects in order to run, but they also require strong donor coordination and capacity in order to maintain their will.

Throughout this research there has been discussion about the successful role of collective diplomacy in the Pacific, particularly through the United Nations. Although many positive outcomes and some of the best examples of collective action have come out of these milestones, there has also been some frustration of the power of the United Nations. As mentioned in the Literature Review, one of the motivating factors that led to establishment of formalised regional organisations was Pacific's desire to take control of their own affairs. Even though they are not donors, Dame Meg Taylor pointed out that dominance is still an issue, where the UN 'set the pace for the region and we should be setting, the leaders should be setting the pace for the Pacific, not by what is driven out of international affairs'. Dame Meg Taylor explained that issues become important at the UN level, and then Pacific missions get involved, the UN agencies, which in turn drive issues and decision making, and then 'there is not the attention paid to what comes out of...the Pacific Islands Forum Leaders Meetings'. Dame Meg Taylor argued that this process comes out of the inclination that if a nation is small, that external bodies and the UN set the agenda. She asserts that, 'to me, so fundamental in the way that regional organisations work and that the work should be done in the region, alongside what the leaders decide plus what their governing councils decide and what the international organisations decide'.

The influence the UN has on Pacific regional organisations is complicated. For many, the UN has much more legitimacy than the smaller supra-national organisations of the Pacific. There are obvious reasons why the UN and particularly PIFS need to remain in close dialogue. The two organisations have strong history and together they are hugely influential to the region. I do not think it would be possible to stop issues or decisionmaking arising from New York, but member countries need to ensure that they keep close ties with the Forum Secretariat, as well as their own national governments. History has demonstrated that the power that the Leaders' meetings can have on 
collective action and change through the UN, and perhaps officials need to be reminded of that.

From the research it is evident that donors are undermining legitimacy, and in turn shaping the public's perception of region and desire to work collectively. Although this dominance is apparent, optimism remains a common theme and many of the participants believed that there were ways to ensure Pacific Islanders had ownership of their organisations. Soli Middleby stated that it can be a challenge for the organisations and other member states, but believes that the relationship can be managed through discussion with Australia and New Zealand. She concluded: 'having two industrialised nations part of the region's major political grouping is on balance more useful than not in my opinion, however it needs to be managed differently'. Alan Morris admitted that it is a difficult 'balancing act', but believes that as a member and a donor, Australia and New Zealand need to play a 'skilful role' to ensure that their government's instructions are delivered while maintaining Pacific ownership.

This role arguably depends on the people who are sitting in the chairs and advising on behalf of the metropolitan states. Firstly, they must believe that Pacific regionalism is an effective or potentially effective way to deliver development outcomes. They also need to understand the importance of the voices of Pacific Islanders in order to ensure that they also have a chance to speak. From my own experience attending these meetings, donor members had a strong responsibility to ensure that they did not dominate the discussion, or intimidate smaller Pacific Island countries into not speaking because they could not offer the same financial backing. This respect needs to come from the Australian Department and New Zealand Ministry of Foreign Affairs and Trade, their ministers and the leaders.

Another suggestion was to strengthen leadership within organisations, or to create incentives for people with excellent leadership capabilities to want to promote regionalism. The anonymous participant argued that 'strong leadership would mean that donors were not allowed to decide the regional priorities and divide and rule regional organisations' Furthermore that 'prominence should also be given to the decisions of the independent island countries'. Dame Meg Taylor stated that the way the budget at the Forum Secretariat is managed ensures that 'certain obligations' are separated from the 
primary budget. That way, the organisation knows 'exactly what is required under our donor funded exercise, that is, say project related, or the implementation components'. Dame Meg Taylor believes that the Framework provides processes to ensure that donors do not undermine the core vision of the organisation, she states:

'the real driver of what we do is not being influenced by or work being skewed by donors...if it doesn't fit in[to our agenda], we have to ask ourselves, where does this fit into the leaders' priorities and the objectives of the organisation. I think it's the biggest challenge of the region'

As discussed earlier, strong leadership benefits the organisations in a multitude of ways. As Max Weber (Weber \& Parsons, 1947) believed, a charismatic and strong leader is one way to seek legitimacy. Strong leadership and support for regionalism would only strengthen management and give the organisations more authority to act on their terms.

Much of the discussion about donors talked about changing the way funds are managed. Currently the large portion of extra funds are mainly given through shortterm projects, and many participants this is a major problem. Participants believed that if donors let 'go the reins and saying look we believe these organisations are fundamentally important for the supra-national governance of the region and so they need a certain amount of funding to exist so we will provide' (Peter Bazeley). Soli Middleby made similar statements suggesting that all donors should move to longterm core funding and 'provide more assistance (such as governance programs that develop regional public policy at a national then regional level) to countries to engage in regionalism'. Donors and members need to be involved in more collective dialogue to discuss the role of organisations and how 'it needs to really serve the regional, supra-national interests of wider member states' to positively influence each other's practices, and also ensure accountability and transparency for all (Peter Bazeley). Furthermore donors should take more steps to harmonise their approaches, as 'there are not that many donors in the pacific but approaches are different and this fragmentation is both harmful at the regional and national level' (Soli Middleby). Peter Bazeley and Soli Middleby both argued that 'donors need to fund projects in a slightly 
smarter way that rewarded that kind of conversation, outcome, impact' (Peter Bazeley), as 'the way regionalism is financed in the pacific does not create the right incentives for it to perform optimally or the 'regional architecture' to work with a common purpose' (Soli Middleby). Soli Middleby argued that countries need to incorporate regional affairs into their national development plans. She believes that 'much more focus is needed at the national level on establishing and agreeing on the level of interest and engagement in regionalism in terms of development and foreign policy'.

The ways that funding is managed are complicated. Dame Meg Taylor noted that the Pacific Islands Forum Secretariat has quite a significant deficit that she is attempting to manage. This track record makes it difficult for donors not to see the risk in long-term budget support or another modality with less control. However, I think that if Pacific people saw that organisations took control of their own finances, they would see regionalism as a more legitimate force. The road to enhancing legitimacy and attracting an adequate amount of financing is difficult. Donors are often sceptical of multi-lateral institutions, and much of the work of Pacific organisations is hard to quantify in value for money terms. As per advice in the Pacific Plan Review 2013, steps have been taken to ensure the Australia and New Zealand directly fund the work plans and core funding of PIFS and SPC. These work plans have been agreed upon by all members and mark a great change in the financing of the organisations (Australian Department of Foreign Affairs and Trade, 2014; New Zealand Aid Programme, 2015). However, there is work to be done and I think that a significant amount of research would need to be carried out in order for all donors to have good incentives to be trustful and adjust to this funding model.

In order to enhance legitimacy for these organisations and provide them with the authority to be able to act, Island members must have ownership over these organisations, and see themselves, not donors, as the power behind the organisations. They need to see their roles as collective decision makers, and not just pursue their national priorities.

\section{Sovereignty and duplication:}

One of the challenges that appears to prevent collective action is state sovereignty. Throughout Pacific regional Communiqués it is made very clear that the organisations 
want to promote state sovereignty. For example, in the Pacific Plan, it states that regional initiatives will not 'replace any national programmes' (Pacific Islands Forum Secretariat, 2007, p. 3). However, how can state sovereignty be protected while fostering collective action and legitimacy?

One of the most common responses to this quandary was that there is a distinct niche for regionalism. Participants noted that there are some issues best dealt with at the regional level, especially with some of the Pacific's capacity restraints (Dame Meg Taylor, Peter Bazeley). However, there is also the issue that member governments are mainly focussed on their national needs, or more their political survival depends on how well they address domestic priorities. Many prioritise national interests over regional affairs, and there is also the issue of the regular turnover of leaders which can challenge ownership of the organisation or particular regional policy decisions or agenda items (Anonymous, Alan Morris). Although the Leaders' Meetings can be quite costly for member governments and organisations, Sir Ratu Kamisese Mara reflected that having the meetings in a different member country each year is extremely beneficial. He argues that it helps promote collective action and gives leaders a chance to understand other nations' challenges (Mara, 1997). Many leaders prioritise their own national pursuits when interacting with regional bodies, instead of collective regional policy and organisational management. This can, arguably, undermine the legitimacy of regional organisations. If leaders are not supporting collective action, then this affects the clarity of the role of organisations, and can undermine the strategic focus. The anonymous participant argued that 'encouraging collective action requires leadership and vision of the benefits of regionalism, sometimes making sacrifices and ceding some sovereignty for the greater good and those who need the assistance most'. Alan Morris supported this statement and noted that at Leaders meetings they 'express lofty ideals about regional issues and regional actions, but by in large, when they go back to their countries they are quite understandably overwhelmed by domestic issues'. Peter Bazeley argued that many of the CROP agencies do not see their role as a supra-national institution, but rather organisations that support national capacity. He believes that this is 'a fundamental issue... [and] surprising because the demand of these organisations is actually on the provision of 
free goods or the subsidisation of services to national governments'. Alan Morris believes that the best way to mitigate this balancing is creating clearer views on how regional organisations:

'cooperate and work with nation states better, work towards greater harmonisation, rather than fragmentation and competition and out of that might come out a concept of regionalism that would complement and marry the purity of the idea of regionalism with the pragmatic demands of a very diverse, fragmented and under resourced group of countries'

As any international relations realist might argue, the nation state is order, while the rest is chaos. Regional organisations present this chaos as their boundaries are not as defined, their power is voluntary, and for many, they have no knowledge or involvement in the decision-making. Yet beyond the chaos, there is a need for their platforms (Milner, 1991, p. 1). It is difficult for leaders and officials to look beyond and be incentivised by what is important for the greater good, or another leader's citizens. Member states must grow to understand that they too will also be more stable if they are willing to support their region. Especially in terms of trade, investment and labour mobility, there are some real opportunities for all members to enhance their national development through a regional mind-set. Pacific countries are different, but there are a lot of similar challenges and environments.

Inclusion

One of the key outcomes of the Framework for Pacific Regionalism has been the inclusion of civil society, the private sector and academia (Pacific Islands Forum Secretariat, 2014). There has been quite a lot of discussion about how this plays out, and who specifically will sit on the table to represent these parties. One participant stated that these groups play a vital role in the region as they have an important role as advocates for regionalism in their communities. They benefit the region by providing a community perspective to what Pacific people want, and help to promote a feeling of ownership (Anonymous). As Dame Meg Taylor stated (at an address at Victoria University in 2015), the inclusion of these groups 'marks a fundamental shift 
away from previous practice, whereby priorities were largely determined by officials or regional agencies ... [and] the opening up of this process has been largely welcomed'. However, other participants were more critical of the process. Soli Middleby acknowledged that these groups need a seat at the table, but argued that if [they are] not focused on specific issues this becomes tokenistic and a waste of time'. Alan Morris was also sceptical of the role, he believes that the concept is 'fine in principle', but argued that:

'while some political leaders are parochial, civil society groups are even more so. In that they have narrow agendas and effective policy making... decision making has to come from a wide view across the whole of society, while civil society organisations pursue very worthy objectives and the worth is more than just about what they think is important. [This] skews what the organisation is doing sectorally rather than corporately'.

Further to the inclusion of the aforementioned groups, sub-regional organisations are also other important players in the regional agenda. Alan Morris believes that many countries are not absolutely committed to regionalism, and this is where subregionalism fits into the agenda. The idea that sub-regional groupings are competing against regional organisations is a common argument. Sub-regional groupings, such as the Melanesia Spearhead Group (MSG), play an important role in shaping the regional political climate, as Dr Tess Newton Cain stated, 'there are all these moving spheres and I think we are going to see a fairly muddled landscape of them merging and forming and alliances separating'. Dame Meg Taylor acknowledged that, just as some issues best handled at the regional or national level, some challenges should be addressed at the sub-regional level. As mentioned in the literature review, there are three specific regions in the Pacific, and throughout history there has been some fragmentation between the sub-regions. Dame Meg Taylor believes that if the end goal is to improve the lives the people of the Pacific, then there needs to be flexibility, 'so it all comes back to in the end, where the benefit is and how the country can implement'.

Civil society, the private sector and academia all play extremely vital roles within the community. To let them voice their opinions and be a part of regional dialogue means 
that more people can be exposed to regionalism and vice versa. Member states will always have the final say when it comes to decision-making, but without the inclusion of these groups, the Pacific region will struggle to be truly collective. As with subregional organisations, it is not useful to see them as a threat to regional organisations. Instead a more logical approach is to accept their existence and expertise, and work together toward a common goal.

\section{Duplication:}

Although sub-regionalism plays an important role in regional affairs, it was acknowledged that there is some duplication between the different organisations (Dame Meg Taylor). Although Dame Meg Taylor believes that this is not necessarily a negative aspect, many other participants expressed different opinions. Anonymous stated that the institutional framework of the region needs to be streamlined in order to ensure that 'there is no mandate overlap and competition for funds both with each other and members'. Peter Bazeley, who has experience with ASEAN, compared the South East Asian regional organisation to the Pacific, stating that it is more complex and covers a broader range of counties, but is about the same size as the Forum Secretariat. There is also the on-going argument about 'who is the alpha male' between the Pacific Islands Forum and the Pacific Community, as they both are getting involved with policy (Alan Morris, also expressed by Peter Bazeley). Alan Morris argued that 'the resources of the Pacific and the capacity restraints should not go to duplication, but in the real world PIFS and SPC cannot always get on'.

Perhaps one of the best solutions to improving issues of duplication is accepting that sometimes it is necessary and not always harmful. The different regional organisations have varying views about issues and different specialisations. This goes back to earlier discussion about the possibility of joining the CROP agencies into one organisation; some disagreement and duplication can help promote robust dialogue. However, communication between agencies and cooperation to assist others or provide different perspectives is probably the best possible outcome. Rather than investing a lot of money into similar projects, there needs to be more communication between agencies. This does not necessarily have to mean another expensive workshop or 
conference, but regular email or phone correspondence. Agencies need plan and share their results, outcomes and future projects with one another.

\section{Conclusion}

This chapter has identified collective action as one of the essential components to enhanced legitimacy. Without the support of each member state, donor, organisation and stakeholder, ownership, and in turn legitimacy, cannot be enhanced. The findings suggested that geopolitics is one of the most important drivers for collective action. Current power and tension within the region are what drive stakeholders together or apart. As Soli Middleby stated 'it is a patchwork and always will be, but there is a desperate need for an honest discussion about its effective and relevance in the 21st century'. This complex 'patchwork' is made up of conflicting ideals and power relations. The discussions between these stakeholders can be messy, but open and frank dialogue is essential to ensure harmonisation and development effectiveness. Democratic consent, one of the tenets of the 'Complex Standard' plays an important role in the legitimacy of these organisations, where Pacific people vote for their governments and in turn vote for the leaders of Pacific regional organisations. This democratic process links all Islanders to regionalism, and provides legitimacy that the organisations will be 'accountable and transparent'. Through improved dialogue, Pacific regional organisations can find opportunities of 'mutual acceptability' and 'comparative benefit' to give the organisations the credibility to act (Buchanan \& Keohane, 2006). 


\section{CLEAR MESSAGE}

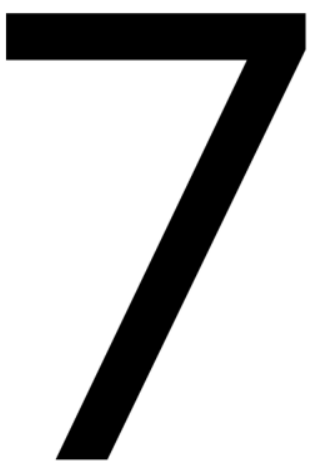

In Dame Meg Taylor's address at the Victoria University of Wellington in 2015, she stated that at the Pacific Islands Forum Secretariat it is 'our role and the role of those who work in regional institutions...to ensure that regionalism remains relevant, and that it delivers tangible benefits to the people of the Pacific'. These types of statements are very common among historical documents, conference minutes and Communiqués, where, for example, leaders have agreed that the organisations need 'fuller dissemination of regional news as a means of increasing mutual knowledge and awareness about development in member countries (South Pacific Forum, 1974, p. 3). However, people are very critical about the access to information in these organisations. And furthermore, it could be argued that unclear mandates cause confusion and duplication across regional organisations, and affect the organisations' individual authority to act conclusively. This chapter questions if Pacific people, from all levels of society, understand the role of regional organisations. It further analyses how Pacific regional organisations can present a clearer message that Pacific people can understand and take ownership over.

On analysis of key documents, the language used is very high-level, full of unexplained jargon, and vague on priorities. The Communiqués are also just written records of these meetings and do not provide thorough accounts of what actually happens behind closed doors. As the 'Standard' argues (Buchanan \& Keohane, 2006), accountability and transparency are key to an organisation's legitimacy. The websites for the Pacific Islands Forum Secretariat use very specific language to the Forum, such as 'Communiqué', 'forum observer' and 'associate membership' without any explanation (Pacific Islands Forum Secretariat a, n.d.). It is very focussed on history and does not clearly explain the role of the organisation in language that people can easily 
understand. The SPC website has a much clearer 'about' or 'mission and vision' page that uses simple language, lists straight forward goals and has regular news updated onto the website. However this is probably partly due to the nature of the organisation and perhaps is an oversimplified account of the actual running of the Pacific Community (Secretariat of the Pacific Community e, 2011) .

\section{Public understanding:}

From my personal experience of working in a Pacific regional organisation, I often struggled to explain exactly what my work entailed, and I found this a common thread when speaking with colleagues. Many people would describe the Pacific Islands Forum Secretariat as the United Nations for the Pacific. The inability to explain what your work entails also extends further to your effectiveness, without clear results that you hope to achieve, it is difficult to track successes and challenges, as well as prioritise your commitments. Working in the Public Affairs Unit for a few months really helped me understand the potential role that public relations and communications play in enhancing legitimacy.

As part of the research process, I read through many communiqués, meeting minutes and publications. As noted above, there were some areas that were more effective at explaining the role of these organisations. It could be argued that one of the essential capabilities of a regional organisation must have to be effective is an ability to demonstrate its relevance to different stakeholders, i.e. its legitimacy. As Peter Bazeley stated 'One thing that came out of the review was that the citizens of the Pacific felt that their voices were not being heard by the political processes effecting the region'.

Firstly, I wanted to ask interview participants whether my own experience with regional organisations was common. However, I felt that all my research of regionalism came through the internet or official publications, i.e. from a position of privilege that could not be easily accessed by all. I then extended it to whether Pacific people at different levels of society also understood it. The overwhelming finding that participants expressed was that 'largely I don't think people understand at all' (Soli Middleby, similarly expressed by Dame Meg Taylor, Alan Morris, Greg Fry, Peter Bazeley). Dame Meg Taylor stated: 
'I think that we can't say that all countries don't understand, I think there are pockets of, where more countries are just much more aware of it, but I also think they are much more aware of what the UN initiatives are compared to the regional initiatives.'

Further from my perception that my knowledge of regionalism comes from my privilege, some participants did mention that many Australians do not understand the role of Pacific regional organisations (Soli Middleby, Dr Matthew Dornan). Dr Matthew Dornan pointed out that many Australians do not understand the role of larger regional platforms or organisations, for example Asia-Pacific Economic Cooperation (APEC). He also suggested that citizens' knowledge of regionalism might not be that important for its legitimacy.

Researcher and critic, Dr Tess Newton Cain expressed some frustration over the lack of information on the inner-workings of the organisations. However, she said that through networks and connections she has created a solid evidence base to be able to understand regional news. She noted that regional organisations are often willing to give out information, but as not many people are asking for it, they probably feel as though it is not necessary unless requested.

However, perhaps the support and interest of people is required for the survival of these organisations. If the public are not interested in regionalism, then will the next generation of leaders care to continue this work? Would it not be better if they could at least give an informed decision, or have access to information in order to be able to make an informed decision? Perhaps it is not important for the public to understand every detail, but transparency is a vital part of legitimacy. In order for people to elect their governments, they need to have information to gain a basic understanding of what they support. The region is huge and many people do not have access to the Internet or forms of media in order to be able to attain this information. Those who do have access struggle to grasp the basic concepts or understand the daily work of the organisations. Even if people are not asking for it, at least if the information is available, people are able to research and learn. Most people do not have the privilege of a wellconnected network that is able to correspond with regional officials or donors to seek out additional information. By educating children of the work of regional organisations, 
they can grow to make informed decisions, think from a regional perspective and understand where the potential benefits are for their sovereign nation.

Alan Morris explained that besides public understanding during the occasional critical juncture: 'I think you would struggle to have a lengthy conversation with most Pacific Island leaders about what regionalism is and why they would support it and what they are prepared to do for them and they for it'.

One of the most common elements that participants argued within this question, was that it is not that the organisations do not convey their role, it is that regionalism means very different things to different parties, i.e. donors, members, policy makers, dialogue members, civil society, or the general public (Alan Morris, Dame Meg Taylor, Dr Tess Newton Cain, Dr Matthew Dornan). As Tess Newton Cain stated: 'It's not a very easy thing to pin down and that sort of conceptual problem is one of the biggest problems/challenges to effectiveness because when you say regionalism or regional approach, it means different things to different people'.

There was also consensus that regional organisations struggled with their own role, as technical institutions or policy makers. Anonymous stated:

'There is probably more understanding of the role of technical agencies given their delivery of technical assistance on the ground. Having said that, technical agencies need to focus on providing technical assistance, the reason for their establishment - so that small states do not have to provide for these specialist technical skills'

Throughout my personal research process, I have struggled to explain to people what regionalism means. I think it is something that each organisation needs to clearly identify on their websites; so that the public can understand the way that regionalism has been understood. However it is difficult because of the changing regional environment, organisations also need to be flexible in their interpretation of the approach. It has been explored thoroughly by the Pacific Plan, the Pacific Plan Review and the Framework for Pacific Regionalism (Pacific Islands Forum Secretariat, 2014; Pacific Plan Review, 2013; Pacific Islands Forum Secretariat, 2007). However, perhaps it needs to be more accessible for people who do not want to read through reports and 
just want a quick overview. Without this very basic understanding, how will people gain ownership over regional affairs and then see these organisations as legitimate?

As mentioned in the literature review, Heiskanen (2001, p. 6) stated that it is not necessary for the general public to have an understanding of these organisations. Alternatively, it is the role of the representatives to be able to understand and communicate regional initiatives to the general public. Or perhaps, the role of representatives to take care of regional affairs and be trusted that they will democratically represent their interests. There is also the issue that there are already too many voices and opinions about regional affairs in the Pacific, so if the general public had too much access to information, the organisations would be overwhelmed and not be as effective. It is clear that the Framework for Pacific Regionalism has definitely made an impact in creating a formalised and methodical approach to public submissions, but would the organisations have the capacity to handle even more submissions if the general public was exposed to their inner workings? How can a balance be found between transparency and accountability, two aspects of the 'Standard' on legitimacy, and managing the capacity of the organisations, while keeping the people of the Pacific informed and happy?

\section{Present a clearer message}

From the findings, it is evident that many people in the Pacific do not understand regional organisations or regionalism. Although there are clear arguments for why it is not necessary for public understanding, all of the regional organisations have mandates to Pacific people and are accountable to its member states. The question then arises, how can these organisations present a clearer message of their roles and responsibilities to all Pacific people, so they can understand and take ownership over Pacific regional affairs?

This argument starts with the very essence of what these organisations aim to pursue: what is regionalism in the Pacific context? This question has been heavily debated in the literature and defined in the Pacific Plan and the Framework for Pacific Regionalism (Pacific Islands Forum Secretariat, 2014; Pacific Plan Review, 2013; Pacific Islands Forum Secretariat, 2007). It is, however, an on-going debate that, as Dr Tess Newton Cain stated it 'means very different things to different people in different 
contexts'. Alan Morris discussed the idea of pure regionalism, and questioned how regionalism plays out in the real world '- especially with diversity of the Pacific - how do regional organisations fit into this?'. He discussed how pure regionalism should be, and the balance between sovereignty and pure regionalism. Furthermore, he argued that regionalism in its purest form has no relevance, and a looser interpretation of the word means that organisation subsidise national capacity. Peter Bazeley argued that there is a need for greater clarity in order for member states and citizens to understand where regional organisations fit into the political agenda (similarly expressed by Soli Middleby, Alan Morris).

In the case of the SPC, Alan Morris stated: 'countries did not really know what SPC was doing. Individual agencies knew, but the information was not provided to members in a comprehensive way, so there was no way of knowing without going to great effort themselves'. However, he did express that steps were needed to improve transparency and communication in the organisation. Participants (Anonymous, Dame Meg Taylor) expressed that SPC is much more straightforward than PIFS because it is a technical services agency, Alan Morris described it as a 'consulting organisation'. Additionally he discussed that SPC aligns its work with the national development plans of its member states, and that is a very loose interpretation of regionalism, and although it is understandable, it is much more like bilateral development. From his work in reviewing SPC, Alan Morris sees the organisation as 'a loose confederation of warring tribes, it is seven programme areas that basically do their own thing...No coherence, no focus in establishing with members countries at higher levels which priorities areas in should be pursuing'.

It is also important to look into the role of the organisations themselves, and how they convey a clear message to their stakeholders. As Alan Morris explained in the case of one of the organisations: 'you have to drill down and consider what exactly the Forum Secretariat thinks that means, and what the leaders of the Pacific think that means'. The organisations have a central role to play in communicating regional messages and their responsibilities, but as evident in the document analysis, this has been difficult. As Soli Middleby stated: 'I think the organisations need to focus on issues that are relevant to people. Tangible things people understand, clear case studies that show, 
through the work of these institutions. No more photos of people in workshops, bula shirts, meetings, etc.' One of the most common findings was that organisations need to use tools, such as social media, to communicate simple messages and have improved communication strategies within the organisations (Anonymous, Dame Meg Taylor). Dame Meg Taylor explained that the Pacific Islands Forum Secretariat has put a lot of work into creating a larger social media presence, especially through Twitter and Facebook, to keep people in engaged. Greg Fry expressed that the other CROP agencies have also "lifted their game [with social media and producing a clear message] over the last three years', suggesting that it may be 'spurred by competition on the participation question with the PIDF'. Anonymous explained that the organisations need to be 'more inclusive including with civil society and the private sector and using them to advocate for us in communities. We also need to deliver results so that Pacific people understand the benefits of regionalism/regional organisations and feel ownership'

However, as Dame Meg Taylor pointed out, member countries of the organisations have 'their own domestic priorities over their regional priorities, their own citizens are much more caught up with what happens at a national level'. Further to this, Dame Meg Taylor established: 'I take it for granted that if a country is a member, it is committed'. However, she argued that as representatives, leaders need to take initiative in communicating the role of regionalism to their citizens and other stakeholders.

Soli Middleby expressed that:

'if regional institutions focused more on evidence based decisions and communicating evidence of what works and what doesn't you could have a better conversation. At present there is not much of a conversation about what regionalism can or should do outside the regional institutions. The institutions should be trying to start that conversation - giving people the history, the potential and the limitations'

Alan Morris emphasised the fragmentation of the Pacific countries 'and operating the way they [Pacific regional organisations] do, doesn't help that fragmentation. There 
needs to be a much stronger and high level relationship between the organisations and their member countries, which would enable robust discussion and debate'

In the case of the Pacific Islands Forum Secretariat, Dame Meg Taylor has established a new system called 'Key Results Areas or KRA' with outcomes as the focus:

'We are working in teams to figure out what our priorities are and the budget is aligned to our key results areas, and it's a much more transparent and open way of working. It's the first time at FOC where countries have said 'this is our institution and we will support it and we want to be behind it'

A strong evidence base that can be easily communicated to the public, leaders, donors, and civil society, as well as other CROP agencies and stakeholders. It would be a huge step toward encouraging legitimacy. Pacific people would understand where their taxpayer money was being spent, and be more engaged with the work of the organisations. Leaders could consider providing more core funding to the organisations and take a more active role in the outputs and results. If donors could see that the organisations represented value for money and presented clear data that regionalism was promoting development, they might be more willing to provide long-term core funding without so many conditions. Other stakeholders would be able to communicate regional approaches to their networks, and get more people involved in these issues. The KRAs of the PIFS are just the first step in creating this vision.

Dame Meg Taylor concluded that this is a big step in reforming the Secretariat and cutting the organisation's financial deficit. She believes it will take time to implement, but there will be quarterly reviews and member states have asked to be involved in the process. Presenting a clear message is about ownership. When people feel that they understand, respect and identify with an organisation, they are more likely to be interested and engaged. This message needs to be presented collectively and requires constant dialogue and reassessment. As Dame Meg Taylor explained: 'The element of legitimacy is when the countries, the member states, take ownership of some of the real challenges that our institutions have to face'. 


\section{Conclusion}

This chapter has discussed and analysed the importance of presenting a clear message. It has explored the idea that without transparency and accountability, it is difficult for stakeholders to understand the work and feel ownership of the organisations. It is a common critique that these organisations do not have clear mandates and it is difficult for those not involved to understand the internal processes (Buchanan \& Keohane, 2006). The chapter questioned whether Pacific people understood regional organisations, and if it was necessary for them to be engaged. Although it may be the responsibility of elected representatives to understand legitimacy, it was discussed that people from all levels of society should have the access to information, and that it would be important for legitimacy in future generations. Participants suggested and analysed how clearer messages could be presented, and there was a common finding of improved dialogue and a larger evidence base. It was concluded that advocacy of these organisations is incredibly important to ensure that Pacific people understand and have ownership over their region. A clear message helps legitimacy as it promotes discussion, helps planning, keeps people more engaged and produces more effective and well managed institutions. The lack of a strong evidence base, and the resulting inability of the general populous to become informed and involved, has led to the predominance of the technical and business elite within these regional institutions. This concentration of technocratic representation may explain why regional organisations have struggled to keep with changing geopolitics. 


\section{CONCLUSION AND RECOMMENDATIONS}

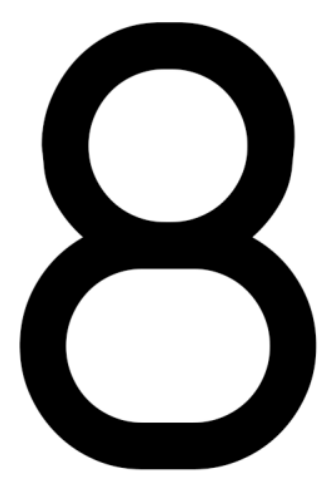

This thesis has explored the complexity of the issue of legitimacy in regional organisations. It has provided context for the importance of legitimacy for these organisations and discussed why this is relevant for the Pacific region. The study attempted to define what legitimacy means for these organisations, and sought to test different elements of the Complex Standard of Legitimacy in the Pacific. The Pacific needs to create effective, inclusive, transparent and member-driver organisations. These ideas have been analysed throughout this research, and a conclusion has been reached that legitimacy is essential if regional organisations want the 'right to rule' (Weber \& Parsons, 1947), and the power to create positive development and influence in the Pacific. This study focussed on the Pacific Islands Forum Secretariat, with a secondary study of the Secretariat of the Pacific Community. These two organisations have differing responsibilities, work across a diverse range of issues in the Pacific, and are both challenged by issues of legitimacy. This chapter will provide an overview of the study, it will: summarise the overall context and motivations of the research; discusses limitations and methods; links back to the theoretical framework; makes final conclusions and suggests recommendations; and introduces future direction for this research.

\section{Research aim}

The key motivation behind this research was my experience as an intern at the Pacific Islands Forum Secretariat. This experience exposed me to the inner-workings of a Pacific regional organisation and gave me insight into the unique challenges of this work. Over this time, I grew to appreciate the often-overlooked concept of legitimacy. The way stakeholders perceived the organisations correlated with the relevance and effectiveness of the work. The aim of this study was to highlight and question the issue 
of legitimacy. It has sought to explore the common themes affecting legitimacy and find practical solutions to enhance the relevance of these organisations to Pacific people. This thesis aimed to contribute to the on-going debate about the future of Pacific regionalism, and question whether these organisations are a relic of the past or a guide to positive development. It has concluded that regional organisations can play a very important role in the Pacific region. There are specific challenges that are best addressed collectively, and therefore members and donors need to cooperate to ensure the effective performance of these organisations.

\section{The foundation chapters}

The literature review looked at global examples of regional organisations, and their legitimacy, while relating this to the Pacific Island context. It demonstrated that in many ways Pacific Island states have adopted regional practices and norms, but the organisations also have their own challenges and contexts. The literature review played an important role in positioning the research and identifying common themes and arguments. There is a lot of history behind the establishment of Pacific regional organisations and, although it was difficult to include all components, the literature review provided a solid foundation in the early stages of this research. The literature review helped discover an important gap in the research, namely the issue of legitimacy, and assisted with highlighting key moments and arguments used to guide the methodology

This research used the qualitative methods of document analysis and semi-structured interviews. Document analysis was used to build the groundwork for the key arguments. Common themes were taken out of the key literature and important documents covered the history of formalised regionalism in the Pacific. The literature helped develop the key interests for document analysis (i.e. critical junctures), and highlight key arguments in the Pacific region for the interview questions. Eight indepth qualitative interviews of key informants were carried out via Skype audio-visual link, telephone and email to further question legitimacy in regional organisations and explore some of the wider debates and experiences. This process of building layers of ideas to create the final method and to achieve the findings was all part of the 
inductive approach: the conceptual framework (see Figure 4). The conceptual framework brought together different aspects of the literature, analysis of historical documents and semi-structured interviews in order to be able to build a picture and create theory. The study used the epistemology of social constructivism, which claims that multiple realities exist and are dependent on how each individual experiences and interprets them. For this reason, the research had a strong focus on human agency and different people's views on the Pacific regional context.

Although steps were taken to mitigate issues and ensure transparency, there were limitations to this research process. Firstly, by selecting an inductive approach there is the assumption that there is no personal bias. However, this is not the case and therefore my positionality was clearly identified in the methodology chapter. Furthermore, by using the epistemology of social constructivism, my role and bias are both important and recognised parts of the research. Secondly, I used contextual analysis for the historical documents. I chose to do this system instead of a more methodical approach as I wanted to research the influence of critical junctures and they are at specific, and not random, moments. Thirdly, I recognise that my interview sample of eight was small. This was a choice I made based on time and the scope of my research. However, each participant was carefully chosen in order to get differing and interesting perspectives. I made an active choice to select key informants in this field; people who were engaged with the subject matter and could provide honest critique. Perhaps future research could expand this work, by interviewing a wider range and larger sample of people (the public, politicians, more decision-makers, etc.). Finally, an important point to note is that due to the social constructivist epistemology of the research, people's views are based on their own experience and their worldview, and therefore there are differing realities (Lincoln, et al., 2011, p. 102).

\section{Findings and discussion}

The findings and discussion chapters used three sub-themes to explore the challenges of legitimacy. These were: critical junctures; collective action; and a clear message. Each of these themes were linked with the overall concept of legitimacy. The subthemes were created out of the findings from the document analysis and literature, 
and discussed different aspects of the Complex Standard of Legitimacy (Buchanan \& Keohane, 2006). These sub-themes were chosen in order to analyse Pacific regionalism in a way that was both in-depth and logical.

Critical junctures is based on a theory discussed in the literature review (Acemoglu \& Robinson, 2012; Development Leadership Program, 2012). This theory suggests that there are moments in history that provide key opportunities for bargaining, and in turn, change. From the literature and document analysis, it was evident that there were clear moments in Pacific regional history where the organisations demonstrated success. Although interview participants believed in this concept of critical junctures, the findings provided a much more complex view. Critical junctures did not occur at regular intervals, could not be fabricated, and are often only clear in hindsight. Furthermore, critical junctures were important at the institutional level, in moments when regional organisations could make their mark and further their roles, but less so at the individual level, where key people seemed to have a more long-term view of the value of regionalism.

Collective action is the most basic form of regionalism. People joining together to work toward a common cause is the basis of cooperation producing effective results. However, as highlighted in the findings and discussion, there are many challenges to achieving this goal. These include: different stages of development, inclusion and exclusion of certain groups, geopolitics and the dominance of some members. A particularly notable finding was the challenge to encourage members to balance regional initiatives with their national priorities, particularly when a leader's national level political survival is at stake. The key findings suggested that in order to encourage collective action, there needs to be more open communication between all stakeholders and improved leadership. Pacific people need to understand the positive role of regionalism in order to work collectively with their neighbours. Without collective action, legitimacy is weak - and vice versa.

Creating a clear message that people can understand and support is an important step toward gaining legitimacy. Without this understanding, organisations can lack transparency and accountability, and this can create an absence of trust. Throughout 
the findings, it was evident that the organisations struggled to communicate clear ideas and thereby gain strong mandates. Furthermore, it was difficult to find and understand the language in many of the conference proceedings and other official documents. Interview participants expressed their support for the need for clearer mandates, as well as a larger evidence base and more accessible information for all Pacific people.

\section{Legitimacy}

The three sub-themes all link back to the overall concept of legitimacy. In this thesis the concept of legitimacy has been argued through the lens of Buchanan and Keohane's (2006) Complex Standard of Legitimacy. Legitimacy is usually defined within the borders of a sovereign state. In the case of a democratic state, the voice of the people and their support are vital to the government's existence and 'right to rule' (Weber \& Parsons, 1947). This can also be related in the scope of global governance institutions, and has clear links with classic state legitimacy definitions. The Complex Standard states that in order for an organisation to be legitimate, it must have: democratic consent; comparative benefit; moral accountability; institutional integrity; accountability; and transparency. These tenets are at the core of this thesis and have been used as a framework for understanding legitimacy and how it can be enhanced in the context of Pacific regional organisations. Overall, these tenets have correlated well with the research and the region. The Pacific is complicated and that is why regional organisations exist and seek the authority to act on these issues. Regionalism creates an important niche to help target some of the world's most difficult challenges. Legitimacy could be achieved if Pacific people could understand their relevance, have the opportunity to be involved in processes, and have access to a clear evidence base for the organisations' value. Then perhaps they would not just understand the need for these organisations, but the need to support them.

\section{Recommendations}

The key findings of this thesis are presented through recommendations. Pacific regionalism is practical, so although there is a theoretical element to this work, feasible policy solutions are arguably the best way to present findings. Many of these recommendations correlate and expand on the Pacific Plan Review (2013). Firstly, one 
of the most common themes throughout the research was the need for a larger evidence base. Steps have been taken in both organisations to create rigorous and objective policy changes, for example through Key Results Areas (KRAs) at PIFS. However, as evident in the findings, this is a process that needs to be improved further. A larger and more consistent evidence base would have a wide range of benefits. Most importantly, this includes improved trust from member countries, donors, civil society and Pacific people. It would ensure that the organisations could track their performance and work to become more effective. If all stakeholders had more trust in the capacity of these organisations, they would be able to see whether there is value for money, and perhaps, donors could take further steps to relax some of their tightly controlled development projects. Secondly, clearer mandates and more communication would be a valuable step toward achieving legitimacy. It would benefit the CROP agencies if they could publish more accessible information that different stakeholders could understand in order to ensure more effective cooperation and harmonisation between issues. CROP agencies could extend the Forum Compact Peer Review (Pacific Islands Forum Secretariat, 2009) process to examine the extent donor and member government actions contributed to a deeper regionalism, e.g. how have donors adapted their funding models; and how have Pacific Island members' governments put in place processes to establish what is best handled at the national level as opposed to the regional level in their countries? This could be done by more effective and inclusive national level debate about development priorities through national level consultative processes. Most countries have a history of national level consultation in putting together development plans, and this could involve all relevant voices were at the table, including civil society and private sector.

From the findings it is evident that Pacific people have little to no idea how they benefit from regional organisations, or how their governments engage with and perform in the various governing bodies, and hence the question their legitimacy. Steps need to be taken to ensure that there is more transparency within regional organisations, so perhaps some type of 'transparency charter' could be adopted by all CROP agencies. They could undertake to make information available on their websites, including all documents and outcome statements from all regional meetings within a 
set time, e.g. seven days. This would enable more accountability of the Regional organisations and would hold national level officials, who represent their countries on governing bodies, to account. Further to this, if regional organisations and governments could work toward more disaggregation of outputs from regional activity at the national level, e.g. what did Tuvalu get from being a part of the SPC tuberculous programme? Pacific people need more information targeting at them that is readily available for all levels of society. For example, a regional news section in local newspapers and magazine. There needs to be more focus through USP to engage young Pacific Island scholars, future leaders and public policy makers. USP is where the region's leaders are being shaped, so perhaps a number of sponsored regional public policy scholarships could be created, or a lecture series on regional organisations.

The third recommendation is to promote the value of strong leadership. Leadership is one of the most basic ideas of legitimacy, and the 'authority to act' and the 'right to rule' are essential to legitimacy. Legitimacy through leadership comes in many forms, whether it is fairly and democratically elected or through the charisma of the leaders' personality (Weber \& Parsons, 1947). However, in the case of Pacific regional organisations, the findings demonstrated that it is difficult to create incentives for good leaders to want to be employed. These organisations do not have the funds to pay salaries similar to the large governments and aid agencies, and therefore it often poses a challenge to staff retention rates. Perhaps there is space to make these organisations more prestigious in order to create incentives for staff. Further from the first and second recommendation, if people could understand the importance of the work and the see the specific value of each Pacific regional organisation, then perhaps the legitimacy would motivate strong and adaptive employees to apply. From my personal experience, an internship programme could be a positive way to introduce young Pacific Islanders to this work, as well as help strengthen capacity within the organisations. If the two key organisations could set up an intern programme with the University of the South Pacific (a fellow CROP agency), then it could help promote legitimacy for the future of Pacific regionalism and expose students to practical work. It could be a completely free option for the organisations with students working a few days a week without pay for a short period of time, or a longer-term programme with 
a small wage paid to students. Alternatively, donors could fund a regional organisation scholarship focussed on regional public policy issues that could include time spent in a donor country university, USP and a relevant CROP agency.

The final recommendation calls for adjusting the role of the secretariats, and correlates with Recommendation 6 of the Pacific Plan Review (2013) ${ }^{11}$. As some participants mentioned in their interviews, they believed that the Framework for Pacific Regionalism needed to be higher-level (not just the Sub-Committee), and be the basis of all work within the organisations. If the secretariats could position themselves to be more strategic and be constantly scanning for critical junctures, and critical issues, then they would be able to provide and facilitate stronger decision-making. Their role would be to maintain their relevance, work on issues that Pacific people were engaged with and provide high-quality advice for leaders. In order to ensure that the Framework can be effective, Leaders, officials and stakeholders need to take ownership over its systems and allow the process to develop. The Pacific Islands Forum Secretariat could establish a review process for the Framework and its component (e.g. the Sub-committee). In order to measure what extent they contributing to a deeper regionalism and integration. It would need to be long term, but a series of intermediate, process level indicators could be implemented immediately, with more complex indicators developed as the process matures. Finally, with issues such as climate change and ocean protection, the Pacific is facing some of the world's most difficult challenges. A positive move for Pacific regional organisations could be to consult and possibly form partnerships with global think-tanks. However, this would need to be done with strong ownership from the organisations to ensure that the work was completed from a Pacific perspective. This option would allow Pacific regional organisations to discuss issues with the most qualified people, and it would mean that the region was engaging in global affairs. If it were managed correctly, engaging with these expert think-tanks could further legitimise Pacific regional organisations by demonstrating to Pacific people their power to make positive change and be leaders in incredibly complex world issues.

\footnotetext{
${ }^{11}$ Recommendation 6 of Pacific Plan Review: PIFS works with PICs (Pacific Island countries and multilateral development agencies to develop uniquely Pacific indicators of both poverty and progress.
} 
Overall, steps need to be taken to encourage all members and donors to buy into the strategies (i.e. Strategic Plans/work programmes). They should all be funding, supporting and monitoring those strategies. Furthermore, members themselves need to understand their roles as members of the board of these organisations and act accordingly. If members and donors can understand the value of the organisations, they will be more likely to prioritise regional approaches (when appropriate), rather than pursue national or bilateral agendas. Being part of a regional membership should mean that members understand they are there to pursue collective regional issues, and in turn make their regional organisations as strong as possible to support these issues. Although, findings suggest that deeper regional integration will be complex and long-term, in order to move towards this there needs to be more buy-in from leaders and more holding of officials to account.

\section{Direction}

This thesis has explored legitimacy in Pacific regional organisations. It has discussed the relevance of regional organisations in the Pacific region, and questioned whether it is an effective form of development. Overall it has adopted a largely positive view of the work and future potential for these organisations. It has, however, focussed on a very small part of the argument concerning Pacific regionalism, namely the issue of legitimacy within two organisations. This research has debated some of the key challenges of regionalism, it has highlighted issues from key informants and provided policy recommendations in order to create strategies for more effective and legitimate organisations. There is definitely scope and need for more extensive research in this field, particularly into the value for money of regional organisations. The financial side of these organisations contributes to stakeholders' overall perceptions, and therefore this type of evidence base would help promote change. This thesis has contributed to an on-going debate about regionalism, however it has given the work a new focus: through the lens of legitimacy. This lens will hopefully have a strong influence on dialogue within regional organisations, academia and civil society. The issue of legitimacy needs to be critically engaged with by both scholars and practitioners if regionalism is to contribute to the positive development of the Pacific Islands region in the future. 


\section{References}

Acemoglu, D. \& Robinson, J. A., 2012. Why Nations Fail: The Origins of Power,

Prosperity and Poverty. 1st ed. London: Profile Books Ltd.

Asian Development Bank-Commonwealth Secretariat, 2005. Towards a new Pacific Regionalism, Manila: Asian Development Bank.

Australian Department of Foreign Affairs and Trade, 2013. Pacific Islands regional organisations. [Online]

Available at: http://dfat.gov.au/international-relations/regional-architecture/pacificislands/Pages/council-of-regional-organisations-in-the-pacific-crop.aspx [Accessed 30 March 2015].

Australian Department of Foreign Affairs and Trade, 2014. Partnership between the Government of Australia (GOA) and the Pacific Islands Forum Secretariat (PIFS) 20142019. [Online]

Available at: http://dfat.gov.au/international-relations/regional-architecture/pacificislands/Pages/partnership-between-the-government-of-australia-and-the-pacificislands-forum-secretariat-2014-2019.aspx

[Accessed 28 January 2016].

Barbour, R., 2008. Introducing Qualitative Research. 1st ed. London: SAGE Publications Ltd.

Beattie, A., 2013. The Governance of Priorities, Financing and Perfromance in the Delivery of Public Goods by International and Regional Membership Organisations. Suva, Independent Review of the Pacific Plan.

Bola-Bari, V., 2015. Fiji returns to PIFS - Fiji Times Online. [Online]

Available at: http://www.fijitimes.com/story.aspx?id=321024

[Accessed 15 January 2016].

Bowen, G. A., 2009. Document Analysis as a Qualitative Research Method. Qualitative Research Journal, 9(2), pp. 27-40.

Buchanan, A. \& Keohane, R. O., 2006. The Legitimacy of Global Governance Institutions. Ethics \& International Affairs, 20(04), pp. 405-437.

Callick, R., 2013. Coup for PNG as least livable city to host 2018 APEC Summit - The Australian. [Online]

Available at: http://www.theaustralian.com.au/national-affairs/foreign-affairs/coupfor-png-as-least-liveable-city-to-host-2018-apec-summit/story-fn59nm2j- 


\section{3}

[Accessed 15 January 2016].

Chand, S., 2011. Reasons for Regionalism. Canberra: University of New South Wales.

Creswell, J. W., 2003. Research Design: Qualitative, Quantitative, and Mixed Methods Approaches. 2nd ed. Thousand Oaks, California: SAGE Publications Ltd.

Crocombe, R., 1975. Seeking a Pacific Way. In: S. Tupouniua, R. Crocombe \& C. Slatter, eds. The Pacific Way. Suva, Fiji: South Pacific Social Sciences Association, pp. 1-6.

Denzin, N. K. \& Lincoln, Y., 2011. Introduction: The Discipline and Practice of Qualitative Research. In: N. K. Denzin \& Y. Lincoln, eds. The SAGE Handbook of Qualitative Research. Thousand Oaks, California: SAGE Publications Ltd, pp. 1-20.

Development Leadership Program, 2012. Coalitions in the Politics of Development, Birmingham, United Kingdom: Development Leadership Program.

Dornan, M., 2014. Pacific Plan Reviewed: what next? - Devpolicy. [Online] Available at: http://devpolicy.org/pacific-plan-reviewed-what-next-20130204/ [Accessed 6 July 2015].

Dornan, M. \& Newton Cain, T., 2014. Regional Service Delivery amoung Pacific Island Countries: An Assessment. Asia and the Pacific Policy Studies, pp. 1-20.

Dornan, M. \& Newton Cain, T., 2015. The Moresby Forum: a reframed Pacific regionalism? - Devpolicy. [Online]

Available at: http://devpolicy.org/the-moresby-forum-a-reframed-pacific-regionalism20150930/

[Accessed 1 October 2015].

East-West Center, n.d.. Pacific Islands Development Program. [Online]

Available at: http://www.eastwestcenter.org/pacific-islands-development-

program/about-pidp

[Accessed 12 November 2015].

Fawcett, L., 1995. Regionalism in a Historical Perspective. In: L. Fawcett \& A. Hurrell, eds. Regionalism in world politics: regional organization and international order.

Oxford: Oxford University Press, pp. 9-36.

Fawcett, L. \& Hurrell, A., 1995. Introduction. In: L. Fawcett \& A. Hurrell, eds.

Regionalism in world politics: regional organization and international order. Oxford:

Oxford University Press, pp. 1-8. 
Ferris, E. \& Petz, D., 2013. In the neighborhood: the growing role of regional organisations in disaster risk management, London: The Brookings Institution - London School of Economics Project on Internal Displacement.

Flax, J., 1990. Thinking fragments. Berkley: University of California Press.

Flick, U., 2009. An Introduction to Qualitative Research. 4th ed. London: SAGE Publications Ltd.

Frazer, I. \& Bryant-Tokalau, J., 2006. Introduction. In: I. Frazer \& J. Bryant-Tokalau, eds. Redefining the Pacific? Regionalism Past, Present and Future. Aldershot: Ashgate, pp. $1-24$.

Fritz, V. \& Menocal, A. R., 2007. Understanding State-Building from a Political Economy Perspective: An Analytical and Conceptual Paper on Processes, Embedded Tensions and Lessons for International Engagement, London: Overseas Development Institute.

Fry, G., 2004. Whose Oceania? : contending visions of community in Pacific regionbuilding, Canberra, Australia: Department of International Relations, Australian National University.

Fry, G., 2008. Australia in Oceania: A 'new era of cooperation'?. In: L. Elliott, G. Fry, W. T. Tow \& J. Ravenhill, eds. Australian Foreign Policy Futures: Making Middle-Power Leadership Work?. Canberra: Department of International Relations, The Australian National University, pp. 9-20.

Fry, G., 2015. Recapturing the Spirit of 1971: Towards a New Regional Political Settlement in the Pacific. State, Society, and Governance in Melanesia Discussion Paper, Issue 3, pp. 1-18.

Fry, G. E., 1994. The South Pacific: From Regional Integration to Collective Diplomacy. In: W. Andrew Axline, ed. The Political Economy of Regional Cooperation: Comparative Case Studies. London: Pinter Publishers, pp. 136-169.

Goff, P., 2006. Pacific Regionalism: Tradition, Continuity, Renewal. In: J. Bryant-Tokelau \& I. Frazer, eds. Redefining the Pacific? Regionalism Past, Present and Future. Aldershot: Ashgate, pp. 25-32.

Gupta, J., 2001. Legitimacy in the real world: A case of the developing countries, nongovernmental organisations, and climate change. In: J. Coicaud \& H. V, eds. The Legitimacy of International Organizations. New York: The United Nations University, pp. 482-518.

Hameiri, S., 2009. The region within: RAMSI, the Pacific Plan and new modes of governance in the Southwest Pacific. Australian Journal of International Affairs, 63(3), pp. 348-360. 
Harvey, W. S., 2010. Methodological Approaches for Interviewing Elites. Geography Compass, 4(3), pp. 193-205.

Hau'ofa, E., 1994. Our Sea of Islands. The Contemporary Pacific, 6(1), pp. 147-161.

Heiskanen, V., 2001. Introduction. In: J. Coicaud \& V. Heiskanen, eds. The Legitimacy of International Organisations. New York: The United Nations University, pp. 1-44.

Huffer, E., 2006. Regionalism and Cultural Identity: Putting the Pacific back into the plan. In: S. Firth, ed. Globalisation and governance in the Pacific Islands. Canberra: ANU E Press, pp. 43-58.

Hughes, T., 2013. The Pacific Plan: vague purpose, shaky ownership, fractured implementation - Devpolicy. [Online]

Available at: http://devpolicy.org/the-pacific-plan-vague-purpose-shaky-ownershipfractured-implementation-20130226/

[Accessed 6 July 2015].

Hurrell, A., 1995. Regionalism in a Theoritical Perspective. In: L. Fawcett \& A. Hurrell, eds. Regionalism in world politics: regional organization and international order.

Oxford: Oxford University Press, pp. 37-73.

Junne, G. C. A., 2001. International Organisations in a period of globalisations: New (problems of) legitimacy. In: J. Coicaud \& V. Heiskanen, eds. The Legitimacy of International Organizations. New York: The United Nations University Press, pp. 189221.

Karlssoon Schaffer, J., 2010. The politics of legitimacy in international institutions, Oslo, Norway: University of Oslo.

Katzenstein, P., 2005. A World of Regions: Asia and Europe in the American Imperium. 1st ed. Ithaca, NY: Cornell University Press.

Lincoln, Y. S., Lynham, S. A. \& G, G. E., 2011. Paradigematic Controversies, Contradictations, and Emerging Confluences, Revisted. In: N. K. Denzin \& Y. S. Lincoln, eds. The SAGE Handbook of Qualitative Research. Thousand Oaks, California: SAGE Publications Ltd, pp. 97-129.

Lodico, M. G., Spaulding, D. T. \& Voegtle, K. H., 2010. Methods in Educational Research: From Theory to Practice. 2nd ed. San Francisco: John Wiley \& Sons, Inc..

Mansfield, E. D. \& Solingen, E., 2010. Regionalism. Annual Review of Political Science, Volume 13, pp. 145-163.

Mara, K. R. S., 1997. The Pacific Way: A Memoir. 1st ed. Honolulu: University of Hawaii Press. 
Mayall, J., 1995. National Identity and the Rival of Regionalism. In: L. Fawcett \& A. Hurrell, eds. Regionalism in world politics: regional organization and international order. Oxford: Oxford University Press, pp. 169-200.

Milner, H., 1991. The Assumption of Anarchy in International Relations Theory: A Critique. Review of Internaitonal Studies, 17(1), pp. 67-85.

Momis, J., 1975. Unity in Diversity. In: S. Tupouniua, R. Crocombe \& C. Slatter, eds. The Pacific Way. Suva, Fiji: South Pacific Social Sciences Association, pp. 81-83.

New Zealand Aid Programme, 2015. Our Partners. [Online]

Available at: https://www.mfat.govt.nz/en/aid-and-development/our-approach-toaid/our-partners/\#Regional [Accessed 10 February 2015].

Newton Cain, T., 2012. Pacific (sub)regionalism - where to next? - ASPI Strategist. [Online]

Available at: http://www.aspistrategist.org.au/pacific-subregionalism-where-to-next/ [Accessed 31 August 2015].

Nye, J. S., 1968. Comparative Regional Integration: Concept and Measurement. International Organization, 22(4), pp. 855-880.

O'Connor, S., 2014. What should we expect from Pacific regionalism? - Devpolicy. [Online]

Available at: http://devpolicy.org/what-should-we-expect-from-pacific-regionalism20140729/

[Accessed 6 July 2015].

O'Neil, P., 2010. Essentials of Comparative Politics. 3rd ed. New York: W. W. Norton \& Company Inc.

Pacific Aviation Safety Office, 2014. Home. [Online]

Available at: http://www.paso.aero/

[Accessed 12 November 2015].

Pacific Islands Forum a, 2015. Forty-Sixth Pacific Islands Forum. Port Moresby, Pacific Islands Forum Secretariat.

Pacific Islands Forum b, 2015. Hiri Declaration: "Strengthening Connections to Enhance Pacific Regionalism". Port Moresby, Pacific Islands Forum Secretariat.

Pacific Islands Forum Fisheries Agency, 2015. Welcome to the Pacific Islands Forum Fisheries Agency. [Online]

Available at: http://www.ffa.int/about

[Accessed 12 November 2015]. 
Pacific Islands Forum Secretariat a, n.d.. About Us. [Online]

Available at: http://www.forumsec.org/pages.cfm/about-us/

[Accessed 12 November 2015].

Pacific Islands Forum Secretariat b, n.d.. Council of Regional Organisations in the Pacific (CROP). [Online]

Available at: http://www.forumsec.org/pages.cfm/about-us/our-partners/crop/

[Accessed 4 November 2015].

Pacific Islands Forum Secretariat c, n.d.. Our Staff. [Online]

Available at: http://www.forumsec.org/pages.cfm/about-us/executive/

[Accessed 15 August 2015].

Pacific Islands Forum Secretariat, 2007. The Pacific Plan: For Strengthening Regional Cooperation and Integration, Suva, Fiji: Pacific Islands Forum Secretariat.

Pacific Islands Forum Secretariat, 2009. Cairns Compact on Strengthening Development Coordination in the Pacific. [Online]

Available at:

http://www.forumsec.org/resources/uploads/attachments/documents/Cairns\%20Com pact\%202009.pdf

[Accessed 15 July 2015].

Pacific Islands Forum Secretariat, 2014. The Framework for Pacific Regionalism, Suva: Pacific Islands Forum Secretariat.

Pacific Islands Forum, 2004. The Auckland Declaration. Special Leaders' Retreat, Auckland, Pacific Islands Forum Secretariat.

Pacific Islands Forum, 2005. Agreement Establishing the Pacific Islands Forum Secretariat. [Online]

Available at: http://www.forumsec.org/pages.cfm/about-us/our-history/agreementestablishing-forum-secretariat.html

[Accessed 1 September 2015].

Pacific Plan Review, 2013. Report to Pacific Leaders, Suva, Fiji: Pacific Islands Forum Secretariat.

Pacific Power Association, 2012. What is PPA. [Online]

Available at: http://www.ppa.org.fi/what-is-ppa/

[Accessed 12 November 2015].

Peebles, D., 2005. Pacific Regional Order. 1st ed. Canberra: ANU E-Press \& Asia Pacific Press. 
Placek, K., 2014. The Pacific Islands Forum Meets in Palau. [Online]

Available at: http://thediplomat.com/2014/08/the-pacific-islands-forum-meets-inpalau/

[Accessed 17 August 2014].

Powell, P. T., 2005. "Too Young to Marry": Economic Convergence and the Case Against Integration of Pacific Island States. In: S. Chand, ed. Pacific Island Regional Integration and Governance. Canberra, Australia: Asia Pacific Press, pp. 218-239.

Radio New Zealand, 2015. Bainimarama accuses Canberra of undermining PIDF. [Online]

Available at: http://www.radionz.co.nz/international/pacificnews/283103/bainimarama-accuses-canberra-of-undermining-pidf [Accessed 10 January 2016].

Rapley, J., 2006. Keynote Address - From Neo-Liberalism to New Medievalism. In: S. Firth, ed. Globalisation and Governance in the Pacific Islands. Canberra: ANU E Press, pp. 1-6.

Russett, B., 1967. International Regions and International Systems. 1st ed. Chicago: Rand-McNally.

Sand, C., 2002. Melanesian Tribes vs. Polynesian Chiefdoms: Recent Archaeological Assessment of a Classic Model of Sociopolitical Types in Oceania. Asian Perspectives, 41(2), pp. 284-296.

Secretariat of the Pacific Community a, 2011. History. [Online] Available at: http://www.spc.int/en/about-spc/history.html [Accessed 2 September 2015].

Secretariat of the Pacific Community b, 2011. Contact SPC. [Online] Available at: http://www.spc.int/en/contact-spc.html [Accessed 2 September 2015].

Secretariat of the Pacific Community c, 2011. Members of the Pacific Community. [Online]

Available at: http://www.spc.int/en/about-spc/members.html [Accessed 20 November 2015].

Secretariat of the Pacific Community d, 2011. Members of the Pacific Community c. [Online]

Available at: http://www.spc.int/en/about-spc/members.html

[Accessed 4 November 2015]. 
Secretariat of the Pacific Community e, 2011. Mission and Vision. [Online]

Available at: http://www.spc.int/en/about-spc.html

[Accessed 15 December 2015].

Secretariat of the Pacific Community f, 2011. Secretariat of the Pacific Community. [Online]

Available at: http://www.spc.int/en/about-spc/history.html

[Accessed 25 June 2015].

Secretariat of the Pacific Community, 2014. SPC's new Director General. [Online]

Available at: http://www.spc.int/en/events/1549-spcs-new-director-general.html

[Accessed 6 August 2014].

Secretariat of the Pacific Regional Environment Programme, 2014. About Us. [Online] Available at: https://www.sprep.org/about-us

[Accessed 12 November 2015].

South Pacific Bureau for Economic Cooperation, 1985. South Pacific Nuclear-Free Zone (Treaty of Rarotonga), Rarotonga: South Pacific Bureau for Economic Cooperation.

South Pacific Commission, 1947. Canberra Agreement: Agreement establishing the South Pacific Commission. Canberra, Secretariat of the Pacific Community.

South Pacific Forum, 1971. Joint Final Communique. Wellington, South Pacific Forum.

South Pacific Forum, 1974. The Fifth South Pacific Forum Communique. Rarotonga, Cook Islands, South Pacific Bureau for Economic Co-operation.

South Pacific Forum, 1976. South Pacific Forum Meeting on Law of the Sea Communiqué. Suva, Fiji, South Pacific Bureau for Economic Co-operation.

South Pacific Forum, 1982. Thirteenth South Pacific Forum Communiqué. Rotorua, New Zealand, South Pacific Forum.

South Pacific Tourism Organisation, n.d.. About SPTO. [Online]

Available at: http://spto.org/about

[Accessed 12 November 2015].

Stewart-Withers, R., Banks, G., McGregor, A. \& Meo-Sewabu, 2014. Qualitative Research. In: R. Scheyvens, ed. Development Fieldwork: A Practical Guide. London: Sage Publications Ltd, pp. 59-80.

Taylor, D. M., 2015. The Future of the Pacific Islands Forum and the Framework for Pacific Regionalism. Wellington: Victoria University of Wellington. 
The Economist, 2015. Europe's future in Greece's hands. [Online]

Available at: http://www.economist.com/news/leaders/21656662-whatever-its-

outcome-greek-crisis-will-change-eu-ever-europes-future-greeces

[Accessed 31 July 2015].

University of the South Pacific, 2013. About the University. [Online]

Available at: http://www.usp.ac.fj/index.php?id=usp introduction

[Accessed 12 November 2015].

Weber, M. \& Parsons, T., 1947. The Theory of Social and Economic Organisation. New York: Oxford University Press.

Wyatt-Walter, A., 1995. Regionalism, Globalisation and World Economic Order. In: L. Fawcett \& A. Hurrell, eds. Regionalism in world politics: regional organization and international order. Oxford: Oxford University Press, pp. 74-121. 


\section{APPENDIX}


Appendix 1: the Framework for Pacific Regionalism process

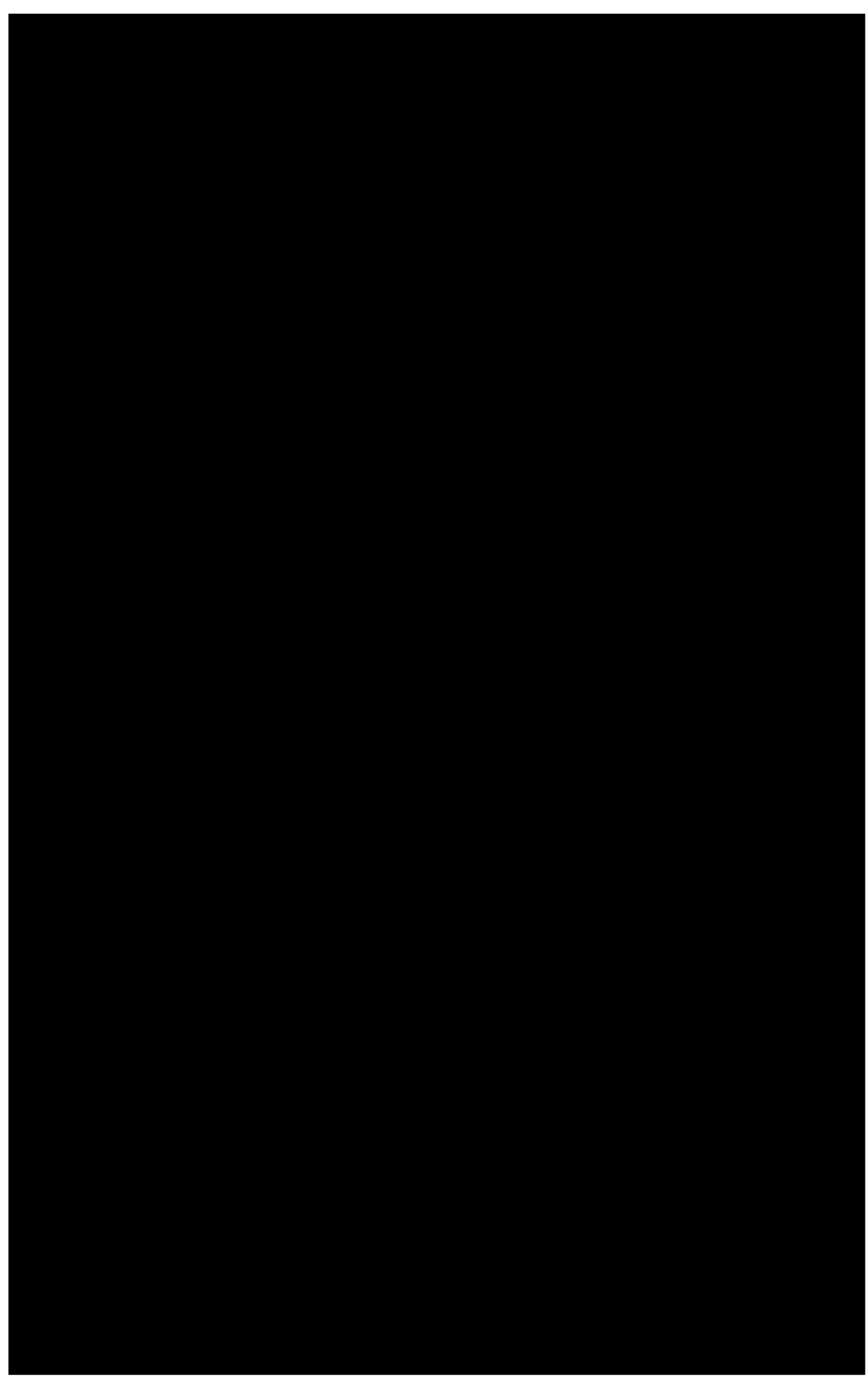




\section{Appendix 2: Victoria University of Wellington Human Ethics Committee forms}
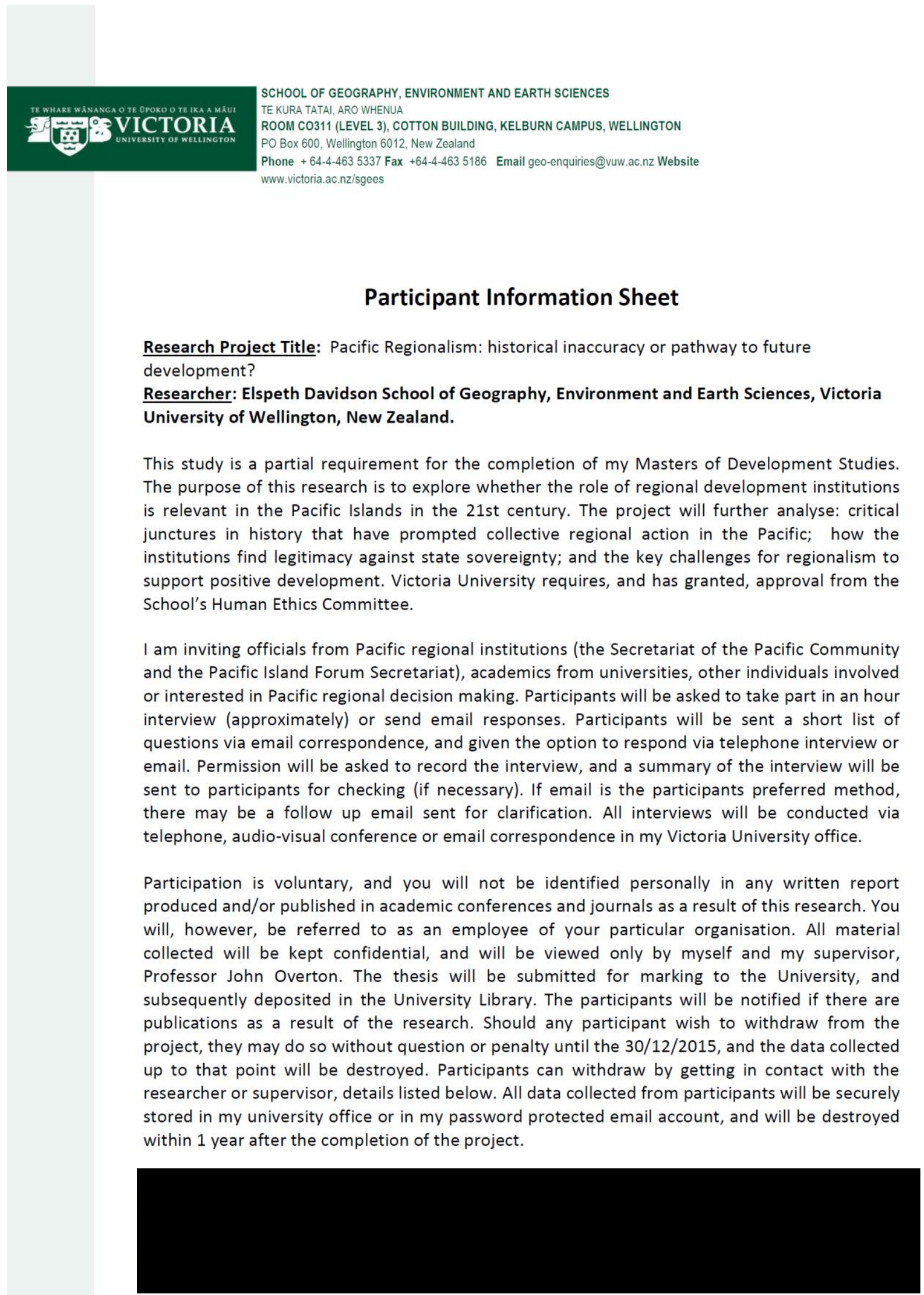


\section{Participant Information Sheet}

Research Project Title: Pacific Regionalism: historical inaccuracy or pathway to future development?

Researcher: Elspeth Davidson School of Geography, Environment and Earth Sciences, Victoria University of Wellington, New Zealand.

This study is a partial requirement for the completion of my Masters of Development Studies. The purpose of this research is to explore whether the role of regional development institutions is relevant in the Pacific Islands in the 21st century. The project will further analyse: critical junctures in history that have prompted collective regional action in the Pacific; how the institutions find legitimacy against state sovereignty; and the key challenges for regionalism to support positive development. Victoria University requires, and has granted, approval from the School's Human Ethics Committee.

I am inviting officials from Pacific regional institutions (the Secretariat of the Pacific Community and the Pacific Island Forum Secretariat), academics from universities, other individuals involved or interested in Pacific regional decision making. Participants will be asked to take part in an hour interview (approximately) or send email responses. Participants will be sent a short list of questions via email correspondence, and given the option to respond via telephone interview or email. Permission will be asked to record the interview, and a summary of the interview will be sent to participants for checking (if necessary). If email is the participants preferred method, there may be a follow up email sent for clarification. All interviews will be conducted via telephone, audio-visual conference or email correspondence in my Victoria University office.

Participation is voluntary, and you will not be identified personally in any written report produced and/or published in academic conferences and journals as a result of this research. You will, however, be referred to as an employee of your particular organisation. All material collected will be kept confidential, and will be viewed only by myself and my supervisor, Professor John Overton. The thesis will be submitted for marking to the University, and subsequently deposited in the University Library. The participants will be notified if there are publications as a result of the research. Should any participant wish to withdraw from the project, they may do so without question or penalty until the $30 / 12 / 2015$, and the data collected up to that point will be destroyed. Participants can withdraw by getting in contact with the researcher or supervisor, details listed below. All data collected from participants will be securely stored in my university office or in my password protected email account, and will be destroyed within 1 year after the completion of the project. 